\title{
QK 192
}

\section{. F6}

Copy 1

\section{FEATURES OF THE FLORA OF IMOUNT RAINIER NATIONAL PARK}
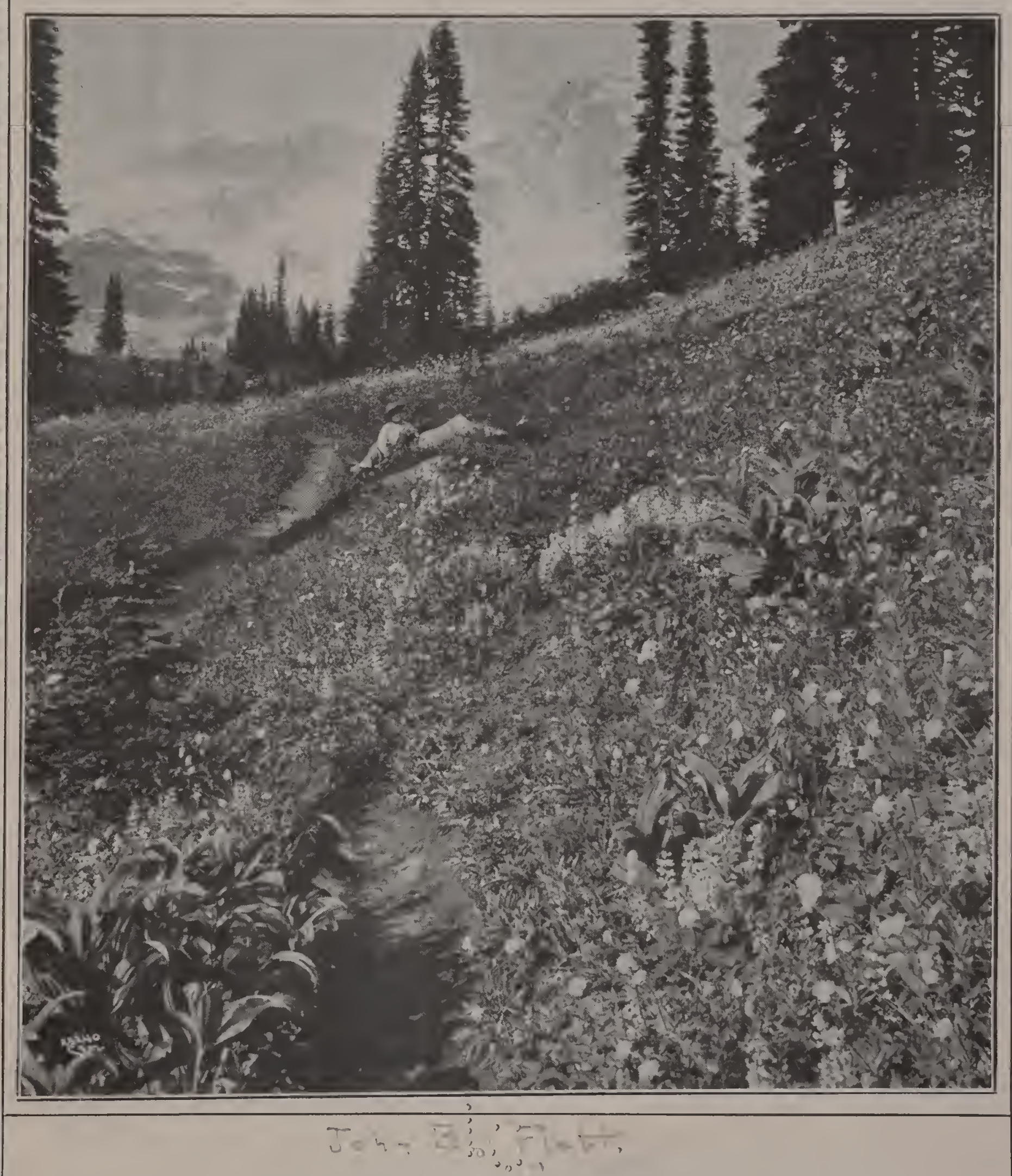

DEPARTMENT OF THE INTERIOR

OFFICE OF THE SECRETARY

$16-263 / 3$ 


\section{PUBLICATIONS OF MOUNT RAINIER NATIONAL PARK SOLD BY THE SUPERINTENDENT OF DOCUMLNTS.}

Remittances for these publications should be by money order, payable to the Superintendent of Documents, Government Printing Office, Washington, D. C., or in cash. Checks and postage stamps can not be accepted.

Forests of Mount Rainitr National Park, by G. F. Allen. 1916. 32 pages, including 27 illustrations. 20 cents.

Contains descriptions of the forest cover and the principal species.

Mount Rainier and Its Glaciers, by F. E. Matthes. 1914. 48 pages, including 26 illustrations. 15 cents.

Contains a general account of the glaciers of Mount Rainier and of the development of the valleys and basins surrounding the peak.

Panoramic view of Mount Rainier National Park, 20 by 19 inches, scale 1 mile to the inch. 25 cents.

\section{D. of D. \\ MAY 11916}

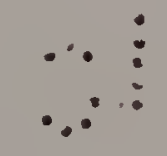




\title{
FEATURES OF' THE FLORA OF MOUNT RAINIER NATIONAL PARK.
}

\author{
By J. B. FletT.
}

\section{GENERAL STATEMENT.}

In a general treatment of the flora of Mount Rainier National Park we must bear in mind the fact that the mountain is located near the center of the park and that the park extends down into the dense forest, thus giving a varied and extensive floria.

For convenience the park may be divided into five zones:

1. The lower area near the boundary, between elevations of 2,000 and 2,800 feet, is composed of wide river valleys covered with large trees around which are woven masses of moss, liverworts, lichens, and ferns. These plants also form a beautiful cover for the forest floor.

2. The upper forest region between elevations of 2,800 and 4,000 feet is characterized by trees covered with gray hanging forms of lichens, smaller trees, and a gradual transition to alpine types.

3. Between 4,000 and 5,500 feet trees are found in groups distinctly alpine alternating with grassy meadows.

4. From 5,500 feet to timber line.

5. Rocky ridges and pumice fields above timber line.

\section{THE FIRST ZONE.}

The first of these zones begins at about an altitude of 2,000 feet, which is the altitude of the river valleys. These valleys, which radiate from the mountain, are of glacial origin. They are broad at their lower ends, but as they approach the mountain they become more narrow and their sides are more precipitous. Aside from their shape the thing that strikes the careful observer is the splendid forest of large trees and the odd forms of plant life which form the beautiful forest cover. These two conditions are nowhere seen to better advantage.

The principal tree in these valleys near the park boundary is the Douglas fir, a well known tree, as it is the most common and the most valuable tree in the Puget Sound region. ${ }^{1}$ The stranger may

\footnotetext{
1 The forest trees are described in a publication entitled "Forests of Mount Rainier National Park," which may be purchased from the Superintendent of Documents, Government Printing Office, Washington, D. C., for 20 cents.
} 
recognize it by its thick bark, cleft into long perpendicular furrows on the large trees, and by the leaves surrounding the branches, from which hang numerous cones with projecting bracts. The next tree in value is the white cedar, Thuja plicata. This is easily recognized by its arbor-vitae like foliage, its thin fibrous bark and spreading base. It is the only cedar or cedarlike tree in that forest until the upper limit where the Alaska cedar begins to come in. The lowland western hemlock is perhaps second in abundance. It may be recognized by its small cones and short foliage silvery white on the lower side of the branches and by its drooping plumelike top, while all the firs have erect tops. There are three true firs scattered through this forest, namely, the lorely, Abies amabilis, the silver, Abies grandis, and the noble, Abies nobitis. The lorcly fir is sometimes called larch by the lumbermen, thus confusing it with a tree which does not grow on the western slope of the Cascades. The lovely fir has scaly bark somewhat like the spruce and a dome shaped top. The foliage is not white underneath; the tree has large purple cones without exserted bracts, which grow only on the top of the tree. The silver fir grows rather sparingly throughout this zone. It can be recognized by its leaves, which are of three different lengths and twisted so that they lie nearly in the same plane on opposite sides of the branch, thus giring it a flat appearance. The branches are generally silvery white underneath, hence the popular name. The bark is of ten white, hence sometimes called white fir. It has small green cones without exserted bracts. This tree flourishes best among alder and cottonwood where there is an abundance of moisture and extends from sea level to about 4,000 feet. The lumber is classed with hemlock by the lumbermen. The noble fir is not abundant in this zone.

The deciduous trees of this zone are the broad-leafed maple, the rine maple, the alder, and cottonwood. The broad-leafed maples are noted for their dense foliage. In the dense forest of tall conifers they often take on an enormous growth of moss, liverworts, lichens, and ferms, which gives them a superficial resemblance to a tropical epiphytic forest, while the rine maples, small and tough, bend over to the ground, forming many fantastical curves and tangles almost impenetrable to the experienced woodsman. These tangles are often made up of several other troublesome shrubs, such as the devil's club, Echinopanax horridum, with its irritating spines, broad palmate leaves, and red berries. The cascar'a, an alderlike small tree, is noted for the medicinal qualities of its bark, which is collected in some localities and shipped in carloads to the eastern market. The willows, spiræas, huckleberries, and the dainty little pachistima are all more or less abundant in this dense forest area.

The herbaccous plants of this region are perhaps the most interesting, because of the many odd forms. The strangest of these belong 
to a group of plants which live on decayed matter. They have lost all green coloring matter which is necessary for self-support and live on the products of other plants. The best known of these strange denizens of the forest is the Indian pipe or ghost plant Monotropa uniflora (fig. 1). 'The former common name is applied to it because of its

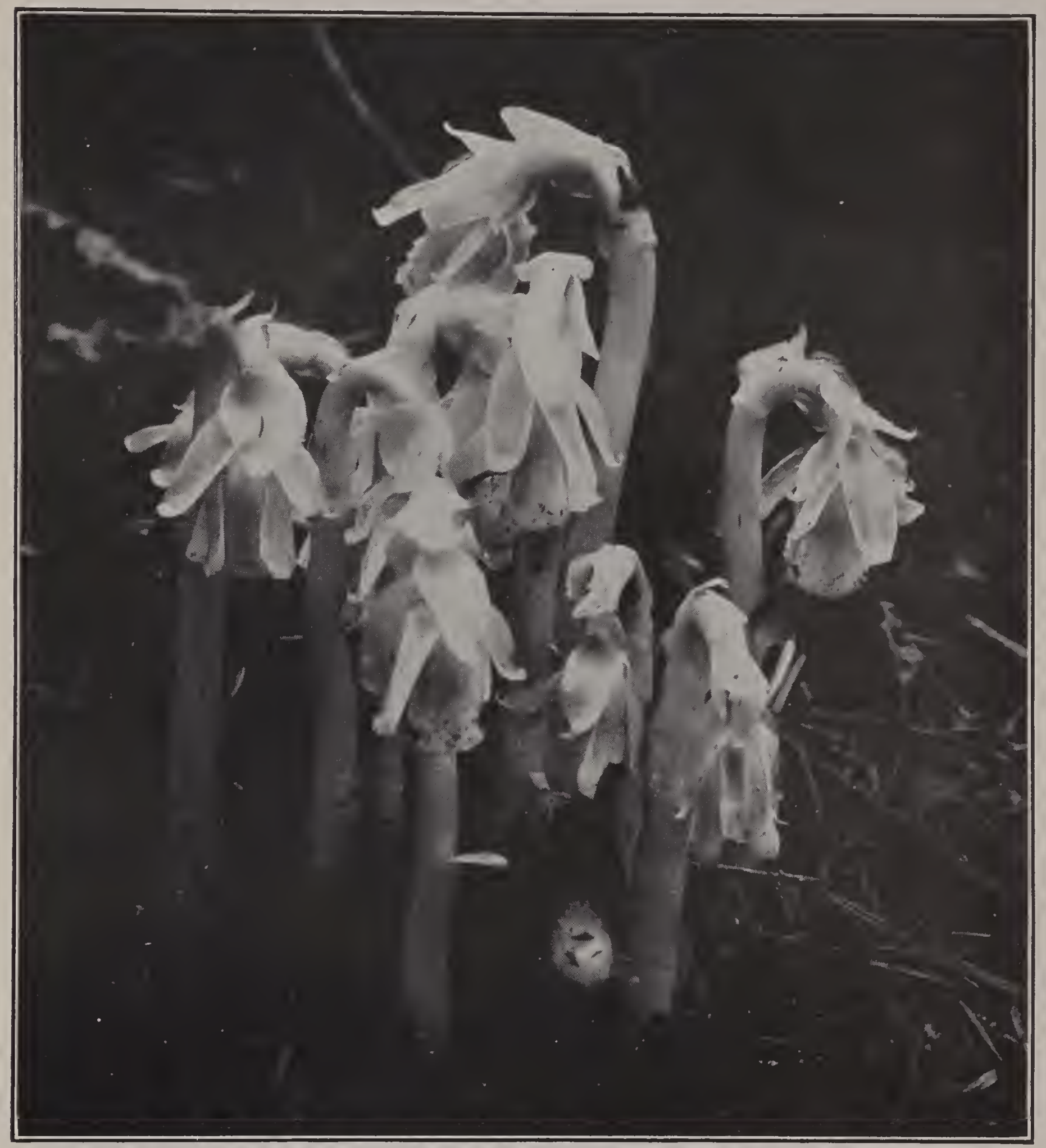

FIG. 1.-Indian pipe or ghost plant (Monotropa uniflora).

Color of flower, white; height of plant, 5 to 12 inches; blooms July and August. Photograph by Asahel Curtis.

fancied resemblance to the ordinary clay pipe, the latter because of its pearly whiteness. This plant has a wide range, extending all over the United States wherever the proper conditions are found. Nowhere is it more at home than in the woods of Washington and Oregon. There is another plant of the same genus which has several flowers on the same stem; this is popularly called the many-flowered Indian 
pipe, while the plant having only one flower is called the one-flowered Indian pipe. The one-flowered species grows in dense clusters, while the other has not this tendency.

The Allotropa, or barber's pole (fig. 2), is a beautiful red and white striped plant confined to the forest of the Pacific coast. It is, perhaps, the oddest of this strange group, because of its bright colors.

The pine sap, Pterospora andromedea (fig. 2), may be recognized by its reddish-brown stem, 3 or 4 feet high, without leaves, and by the numerous globular flowers arranged along the upper part of the stem. This plant, like the Indian pipe, has a wide range, extending across the continent. Locally it extends from about 1,000 feet above sea level to about 3,800 fect. The rarest of this leafless group is Hemitomes congestum (fig. 2). It is so rare that it has no common name. Like the one-flowered Indian pipe, it grows in dense clusters. The writer saw one bunch collected below the park entrance that filled an ordinary milk pan. Not only do these plants grow in dense masses but the flowers on each plant are also massed together, as the specific name indicates. In its prime it is a beautiful rose-pink or sometimes nearly white, but with age it turns black like nearly all of the Indian pipe family. It extends from near sea level to an altitude of about 3,200 feet. On the southeast slope of Mount Angeles, near an old deserted cabin, the writer found the five species shown on figure 2. The plants were collected and placed hurriedly on an old table and photographed with the side of the log cabin for a background.

Closely related to this leafless group is the Pyrola or wintergreen family, which is well represented and seems to be a connecting link between the Indian pipe family and that of the heath or heather family. In the old textbooks all three families are included in the heath family. The name pyrola means a little pear, from the fact that the thick shining evergreen leaves resemble those of a pear tree. These species are easily recognized in the dense forest. Pyrota. secunda is known at once by its one-sided raceme of small greenish flowers or seed-pods. The wintergreen of commerce is not obtained from any of the western species, but from the false wintergreen or checkerberry of the East. This plant is more abundant in the second zone. Pyrola aphylla, as the specific name indicates without leares, has small bracts. Pyrola bracteata has rather large round or elliptical leaves in a rosette with flowers in a raceme. This plant resembles the eastern "shin-leaf." Still another, Pyrota picta, might be added. This may be recognized by the white spots or streaks in its rather long leaves. Moneses uniflora is a beautiful little plant of this small family. It may be known from the pyrolas by its single waxy flower. Its generic name signifies "delight." It is needless to add 


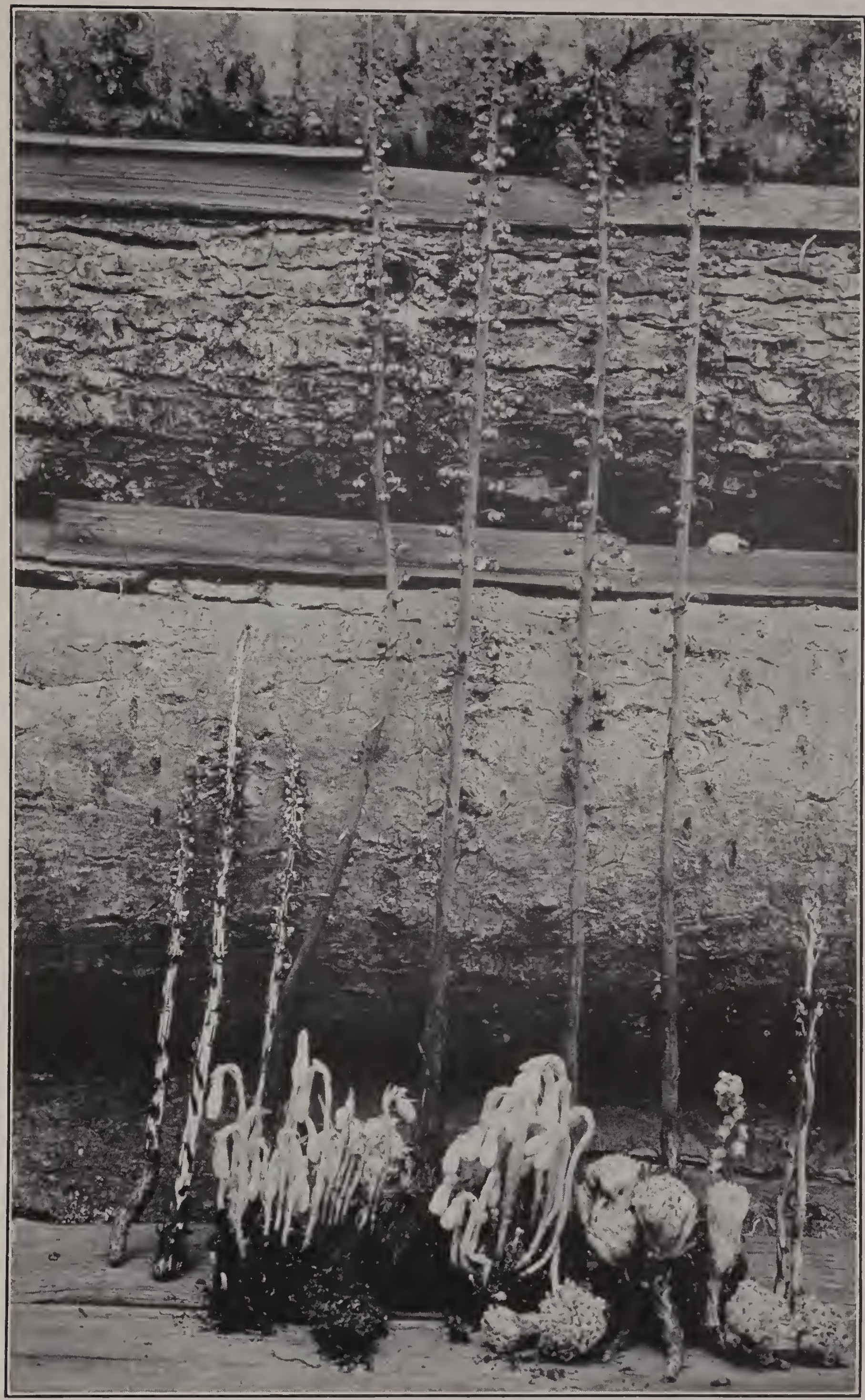

FIG. 2.-Barber's pole (Allotropa virgata) on left; ghost plant or Indian pipe (Monotropa uniflora) to right of barber's pole; many-flowered Indian pipe (Iypopitys hypopitys) on right; Hemitomes congestum, massive flower near right corner; pine drops or pine sap (Pterospora andromedea), tall plant against logs in background. 
that it is worthy of its name, as it will surely delight the heart of its finder.

To this family also belongs the prince's pine or pipsissewa, which is common in these mossy woods. It is a more robust plant than the pyrolas, with narrower oblanceolate leaves and an umbel of waxy

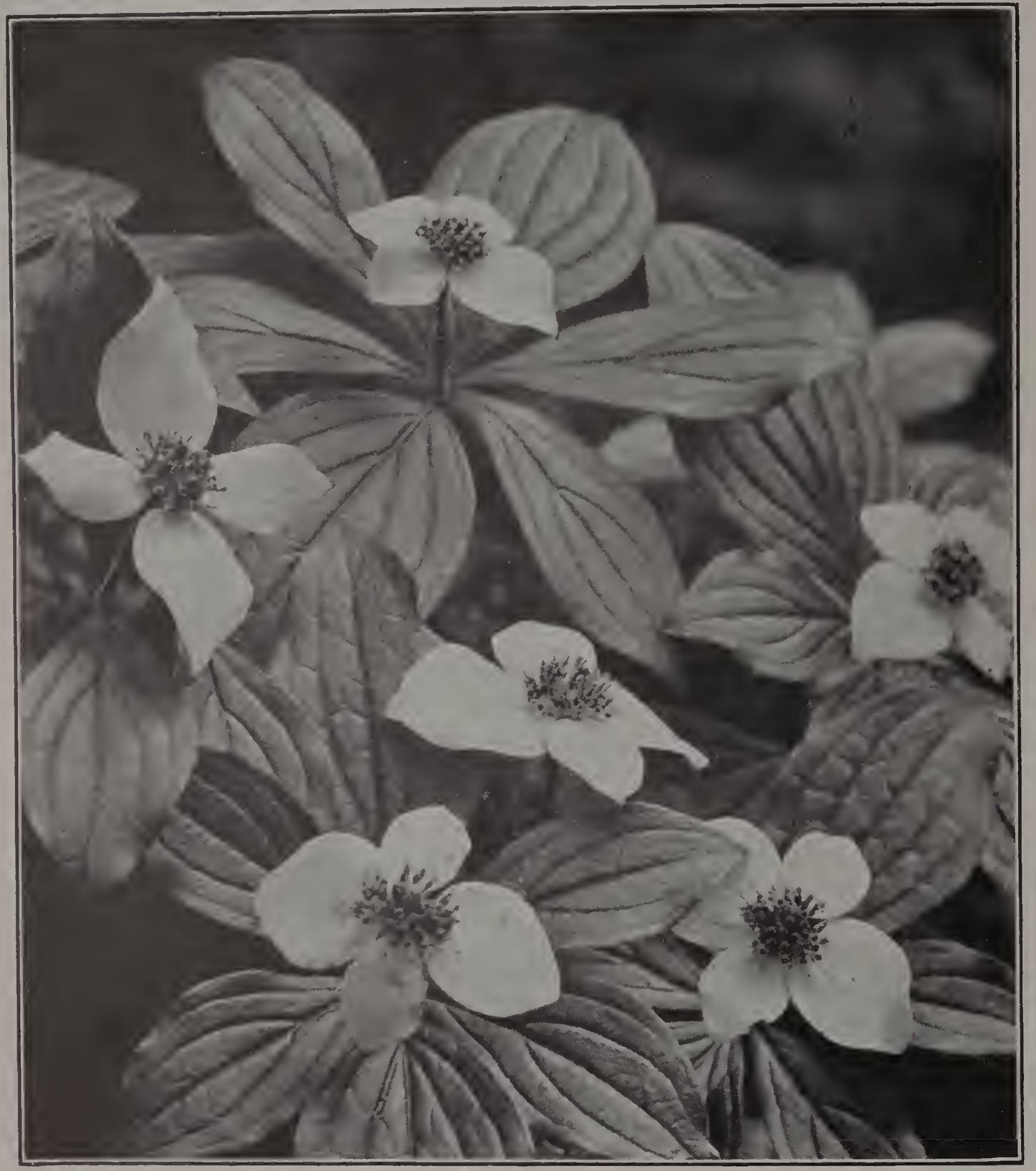

FIG. 3.-Canadia dogwood (Cornus canadensis).

Color of flower, greenish white; height of plant, 3 to 8 inches; diameter of head, 3 to 1 inch; blooms Jume to Norember.

Photograph by A. H. Barnes.

flowers. It is common through the United States and Canada. Menzies's prince's pine is a much smaller plant with variegated leares and is restricted to the West. This, like most of its relatives, has somewhat waxy flowers. In localities where the soil is poor the salal, a plant which is nearly always present in the fir woods, is abundant. It has leaves somewhat the shape of the trailing arbutus 
of the Eastern States, though the salal has a more erect habit of growth, with its zigzag stem and raceme of white urn-shaped flowers and bluish-black berries. The red, black, and blue huckleberries are also common here, especially in openings through the forest.

Present everywhere is the Canada dogwood, Cornus canadensis (fig. 3), with its creamy-white heads surrounded by four bracts which look like petals. Inside of these bracts are the real flowers, which are small. It is difficult to tell whether this plant is more beautiful in flower or in fruit. The fruit consist of a beautiful bunch of bright red berries which hang on for a long time. No plant receives more

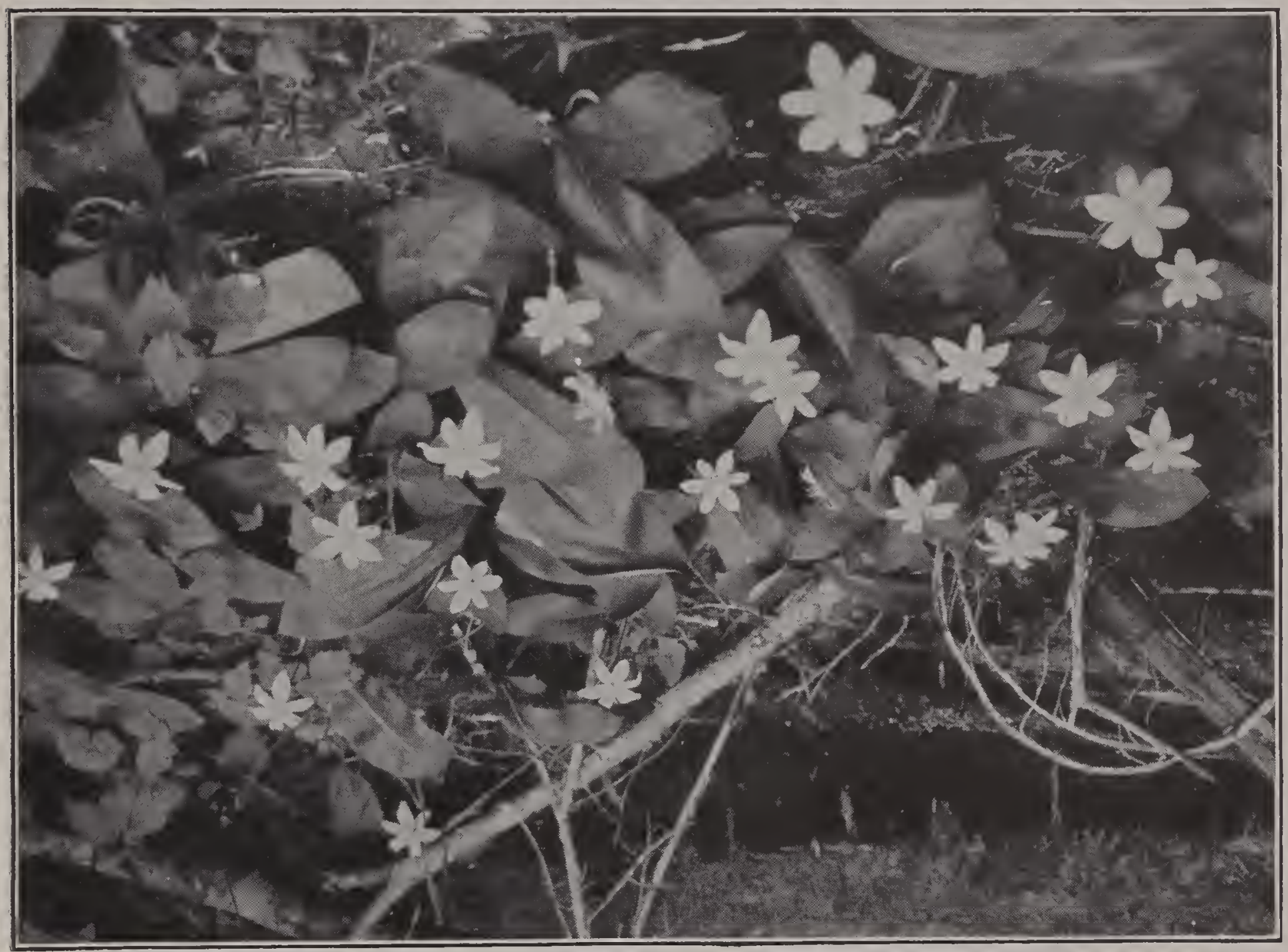

FIG. 4.-Alpine beauty (Clintonia uniftora).

Color of flower, white; height of plant, 2 to 4 inches; blooms July and August.

Photograph by J. B. Flett.

attention and praise from the tourist than does this little dogwood. In some localities in the East it is popularly called "bunchberry." On close examination its relationship to the large flowering dogwood can be plainly seen. The Canada dogwood is in bloom a second time late in the fall. Mixed with the little dogwood is the pure-white alpine beauty, Clintonia uniflora (fig. 4). This species, with its single flower of six petals, surpasses in beauty its eastern relatives. 'This liliaceous plant is little known to those traveling through the mountains. It belongs to the lily-of-the-valley family, as do the false solomon seals which often bloom with it in July and August. 
The Clintonia has three radical elliptical parallel-veined leaves and a single terminal flower. Its fruit consists of a blue berry. There are three species of the false solomon seal in this region-two species of twisted stalk and the ovate trillium-all of which belong to the lily-of-the-valley family.

The Oregon wood sorrel, Oxalis oregona, is extremely abundant and grows with those just mentioned. It has white or pinkish-white flowers and leaves of three obcordate leaflets resembling clover. The juice of this plant is extremely sour. Visitors frequently refer to it as that "cloverlike plant in the woods." A bishop's cap, Tiarella trifoliata, has a delicate raceme of small white flowers and pubescent

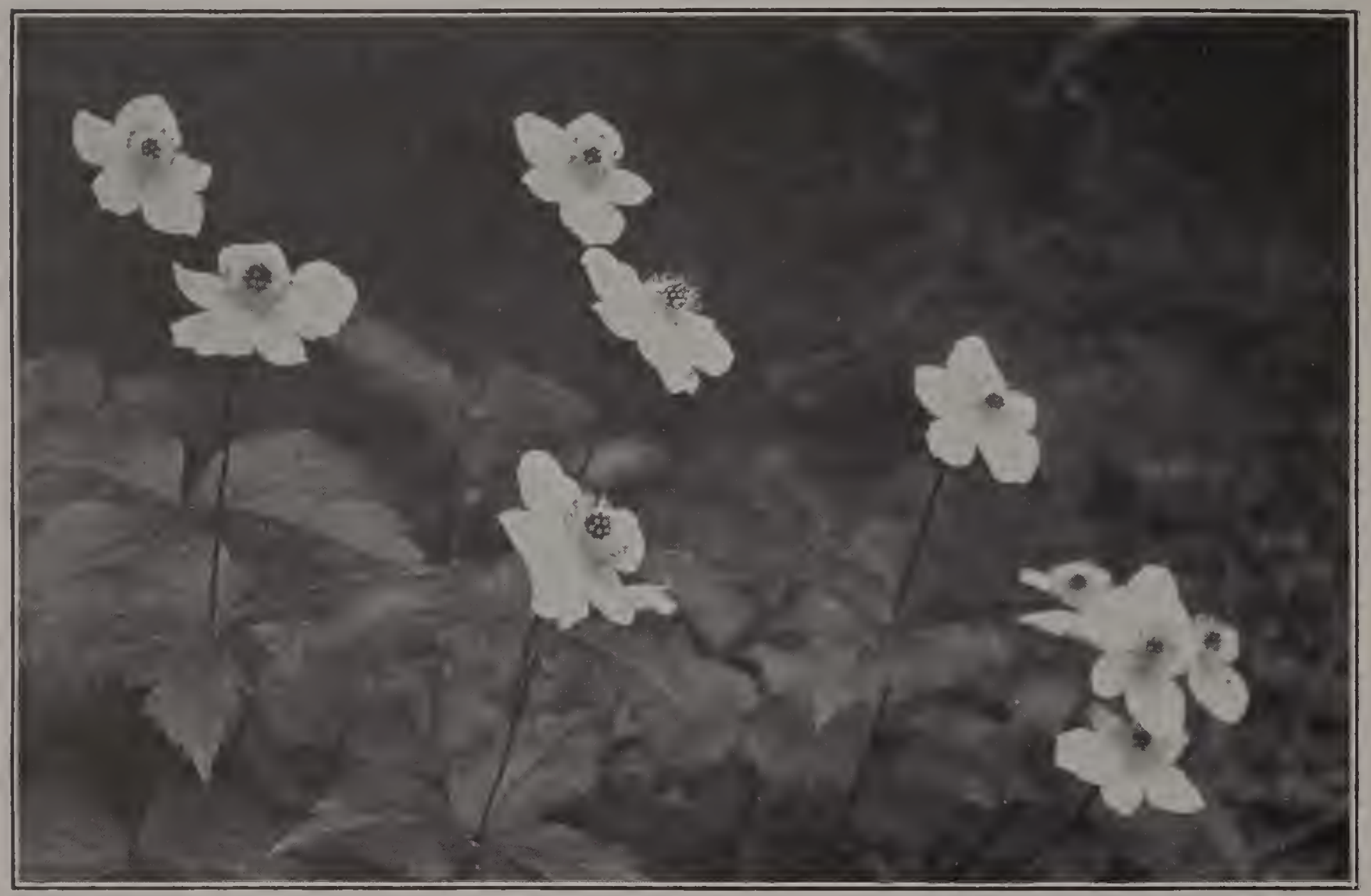

FIG. 5.-Forest anemone (Anemone deltoidea).

Color of flower, white; height of plant, 6 to 11 inches; blooms June to August. Photograph by A. H. Barnes.

trifoliate leaves. This plant extends from sea level to about 2,900 feet, when its leaves appear gradually to change from their trifoliate character to unifoliate. All intermediate forms can be found. When the transition is complete it is rechristened Tiarella unifoliata. It extends in this form to the terminal moraines of the glaciers or above.

The forest anemone, Anemone deltoidea (fig. 5), forms beautiful spots here and there because of its creeping roots, which tend to intertwine and bring the slender stems together. The leaves are rhomboid serrate with trifoliate leaflets. The delicate white flowers last a long time here in the dense shade. The fruit is not conspicuous, like that of its relative, the western anemone (figs. 6, 7, and 8), in the grassy meadows. 


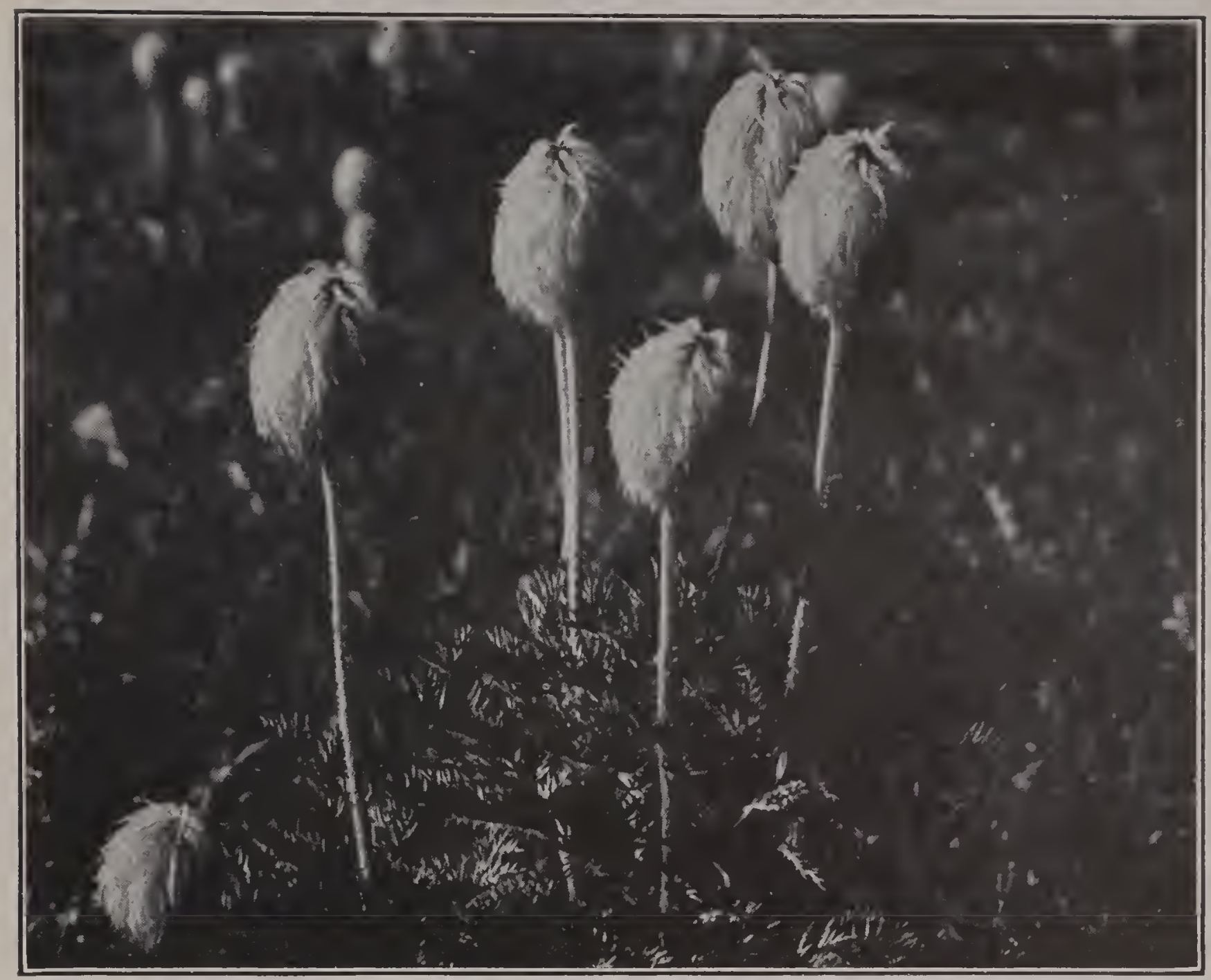

FIG. 6.-Seed pods of anemone.

Color of flower, lavender; height of plant, 8 to 20 inches; blooms July and August. Photograph by Asahel Curtis.

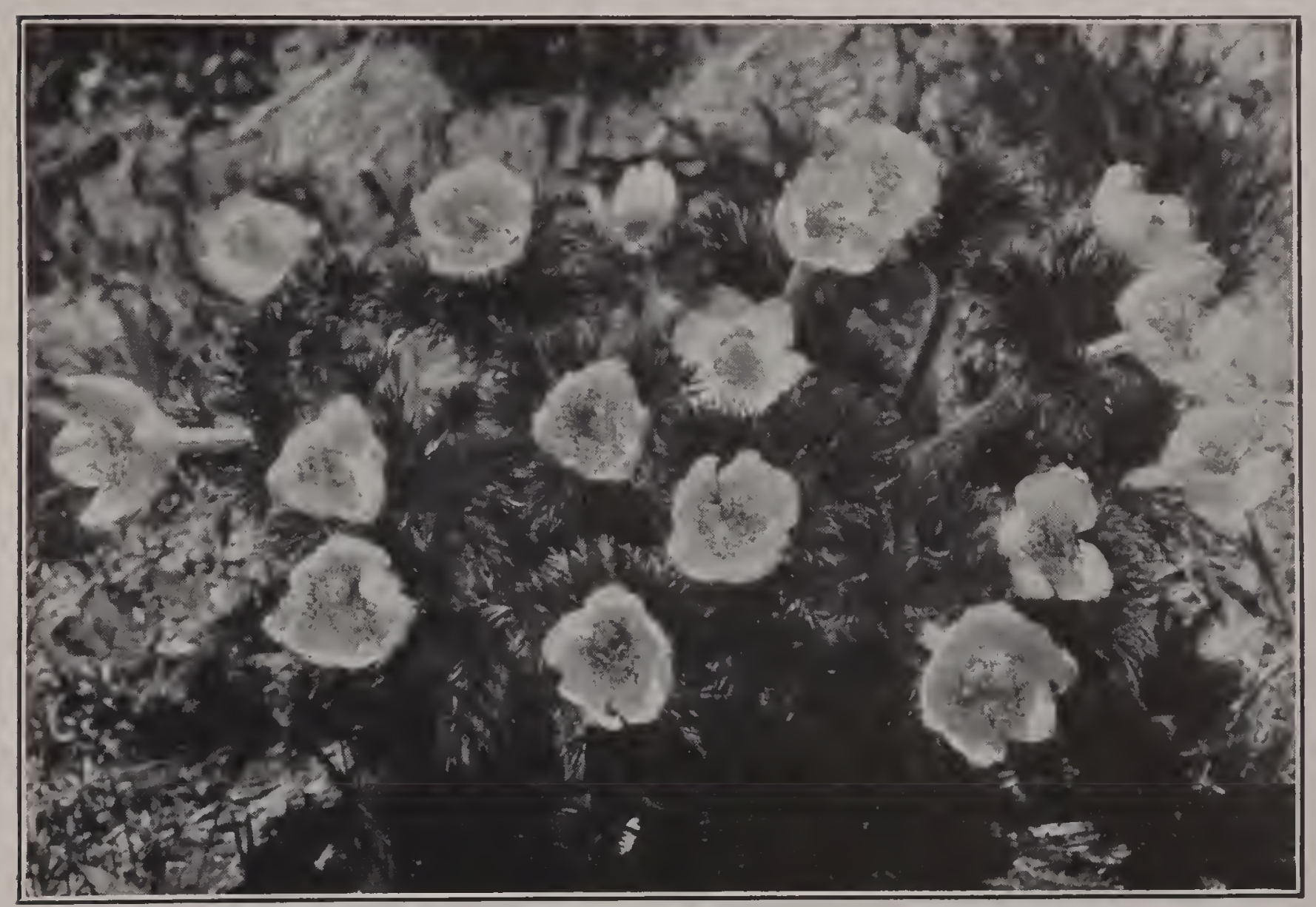

FIG. 7.-Western anemone (Anemone occidentalis.) 


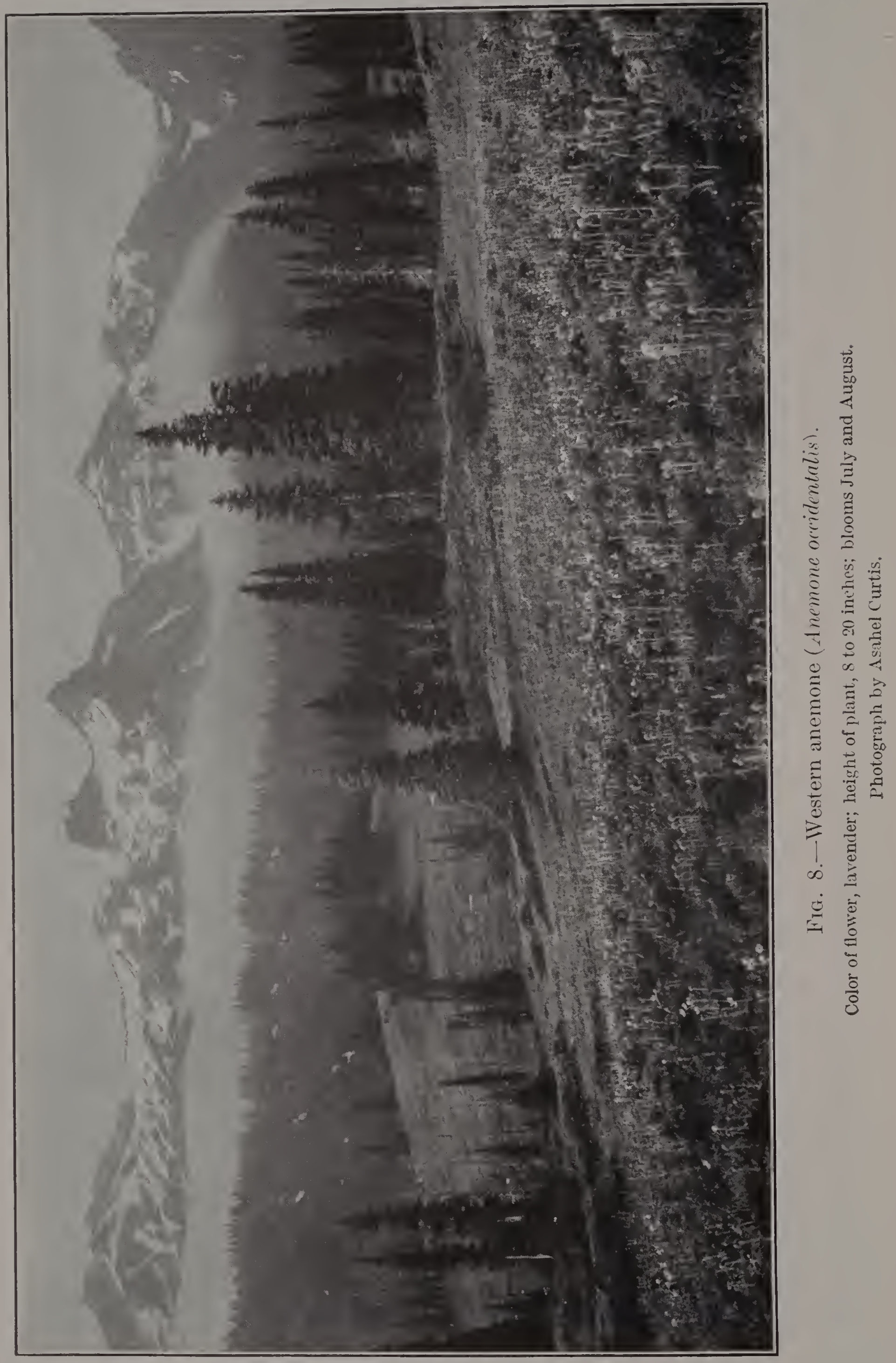


The orchid family also has several members. Perhaps none are more conmon among the moss than the twayblades. These plants can be recognized by their odd-shaped small green flowers and their slender stalks bearing two opposite cordate parallel-veined leaves. The coral root has a brownish leafless stalk rising from a coral-like mass for a root. These plants grow in clusters. One species, Corallorhiza striata, has striped petals and no spur, and the other, Corallorhiza multiflora, has spots on the petals and conspicuous spurs. The most popular plant of this family is the lady slipper, Cytherea bulbosa or Calypso borealis. This plant blooms a little too early to be in its prime at the rush of tourist travel to the park. It is, however, often found and admired in the early part of July or later. This is considered rare in the Eastem States, but grows abundantly here in the mossy woods. Bikukulla formosa, a western form of the dutchman's breeches, is not at all rare. Its near relative, the wild bleeding heart, Capnoides scouleri, is very abundant and vies with the bracken in size. It is well known to the children of the neighborhood, who amuse themselves by touching the mature seed pods, which "pop" and scatter the seeds in all directions. It has pink flowers and large triangular leaves.

Neatly interwoven through the green mossy carpet is the long trailing Lycopodium clavatum. This often has a length of 20 feet with many side branches. It has received a number of popular names such as Christmas wreath, ground pine, and staghorn moss. It is often collected in the foothills of the mountains before Christmas and shipped to the cities for decorative purposes. Sometimes it is stained or dyed after the manner of the so-called "air plants" of the Japanese and woven around pillars or strung from one place to another. The artificial color will last longer than the natural. There is also a shorter and more erect species often growing with the above called L. lucidulum. The slope of the Tatoosh Range near the trail leading down into Stevens Canyon is thickly interwoven with the former species. There is a marked difference between that grown in the dense woods and that on an exposed slope.

No plants contribute more to the beauty of the shady part of the park than the ferns. Everyone in this vicinity is familiar with the sword fern, which reaches its highest development in the rich soil of these shady retreats. The deer fern, Struthiopteris spicant, which is more slender than the sword fern, is also abundant. It has two kinds of fronds; one grows erect from the center and bears the spores for reproductive purposes, while the other, which spreads out in radiate form, is much broader and greener and is well adapted to perform the vegetative functions. The latter fronds are evergreen, while the contracted spore-bearing fronds die down at the 
close of the season. The licorice fern, Polypodium occidentale, grows cmbedded in moss-covered trees and sometimes on old logs, while the maidenhair fern selects waterfalls and moist cliffs.

The common brake grows abundantly all through the lower zone and sometimes forms thickets with other vegetation. The western form of the lady fern sends up its tall broad fronds in tufts here and there, generally where there is an abundance of moisture. Somewhat resembling the lady fern is Dryopteris spinulosa ditatata, which generally grows in similar localities. The lady ferm is smoother than Dryopteris spinulosa dilatata and has kidney-shaped fruit dots on the back of the frond, while the fruit dots on the latter are round. The dainty oak fern, Phegopteris dryopteris, is everywhere present among the moss. It has a dark-colored stem and triangular frond. It is much smaller than the two last mentioned and extends into the higher portions of the park.

\section{THE SECOND ZONE.}

There can be no sharp line of demarcation separating the first and second zones, yet no one can fail to note the difference in the flora in a few hundred feet of ascent. There is, for instance, a difference between the park entrance and Longmire Springs. The trees as a rule have become smaller except along the border of the low swampy ground adjoining the Longmire property and its continuation up along the Henry Hunting Ground trail. Not only have the trees become smaller, but different species have come in. The white pine, Pinus monticola, occasionally seen below, now becomes common. It can be recognized by its fine silky foliage, its large cones and five needles or leaves in the bunch. On the pines the leaves are never separate as on the firs, but are apparently tied together at the base and inserted into the branch. The bark of the white pine resembles a checkerboard. The black pine has two short leaves together. At Longmire Springs the white and black pines grow side by side. The black pine has dark foliage and numerous small prickly cones about an inch or two in length while the white pine has cones 8 or 10 inches long without spines.

The common and the Alaska cedars also have a common meeting ground bere. The Alaska cedar has globular fruit which distimguishes it from the white cedar. Aftcr a little practice the two species of cedar can be distinguished by their bark and foliage. The wood of the Alaska cedar is yellow with a characteristic odor and becomes hard when dry, in marked contrast to the soft wood of the lowland cedar. In this vicinity the Alaska cedar seldom reaches 3 feet in diameter, though occasionally old fallen $\operatorname{logs}$ of far greater diameter are found in low places in the forest. The lumber 
of these large trees is considered rery valuable on account of its hardness and fine grain.

On account of the character of the soil the trees mentioned above do not attain their highest development. This is especially true of the hemlocks. The hemlocks can be distinguished by their foliage. The lowland hemlock has numerous small cones and foliage that is white on the lower side. The alpine hemlock has cones $1 \frac{1}{2}$ to 2 inches in length and there is little or no difference in the color of the upper and lower sides of its foliage.

The Douglas fir from this point begins to give way to other types. This is also true of the white cedar. The lowland hemlock, on the other hand, forms nearly pure forest at 3,200 feet and higher. The noble fir seems to reach its highest development just below the glaciers at an altitude of about 3,900 feet. · Just below the Nisqually Glacier theforest is composed more largely of this tree than any other locality with which the writer is familiar. In the distance these trees can be recognized by their peculiar blue-green color which is very different from the color of any other coniferous tree. They have large cones covered by long exserted green bracts. The noble fir is usually accompanied by the lovely fir. In the upper part of this zone the alpine fir is common, so that the forest has a decidedly changed appearance. Here the valley has become very narrow and the trees grow mostly on steep mountain slopes. Occasionally the wake of the avalanche can be distinctly' seen where the trees have been swept away. Where this is of common occurrence there is little or no vegetation, only the bare rocks or gravel, but where this happens at long intervals new trees start up and grow until they in turn may be destroyed.

In wet places a spruce occurs in the tree groups of the meadows. On the south side of the mountain the spruce is seldom seen, though it is common on the north and east sides.

Several species of Usnea, a lichen, become attached to the trees and give them a light gray color. These hang down from the trees in long thread-like tufts which give the trees a drooping or weeping appearance. These pendant lichens are popularly called Spanish moss, confusing it, perhaps, with Tillandsia, a thread-like vine which grows so profusely on the trees in Florida. In neither case is the name appropriate. How different is the aspect of the forest here, clothed in its garb of light gray drooping thread-like lichens, from the majestic trees of the lower forest in their apparently tropical attire.

Many of the shrubs of the lower valley continue on up into the second zone. The white rhododendron, $R$. albiflorum (figs. 9 and 10), a beautiful shrub of the huckleberry family, enriches this area with its creamy-white flowers and glossy rariegated leaves. It is said, how- 


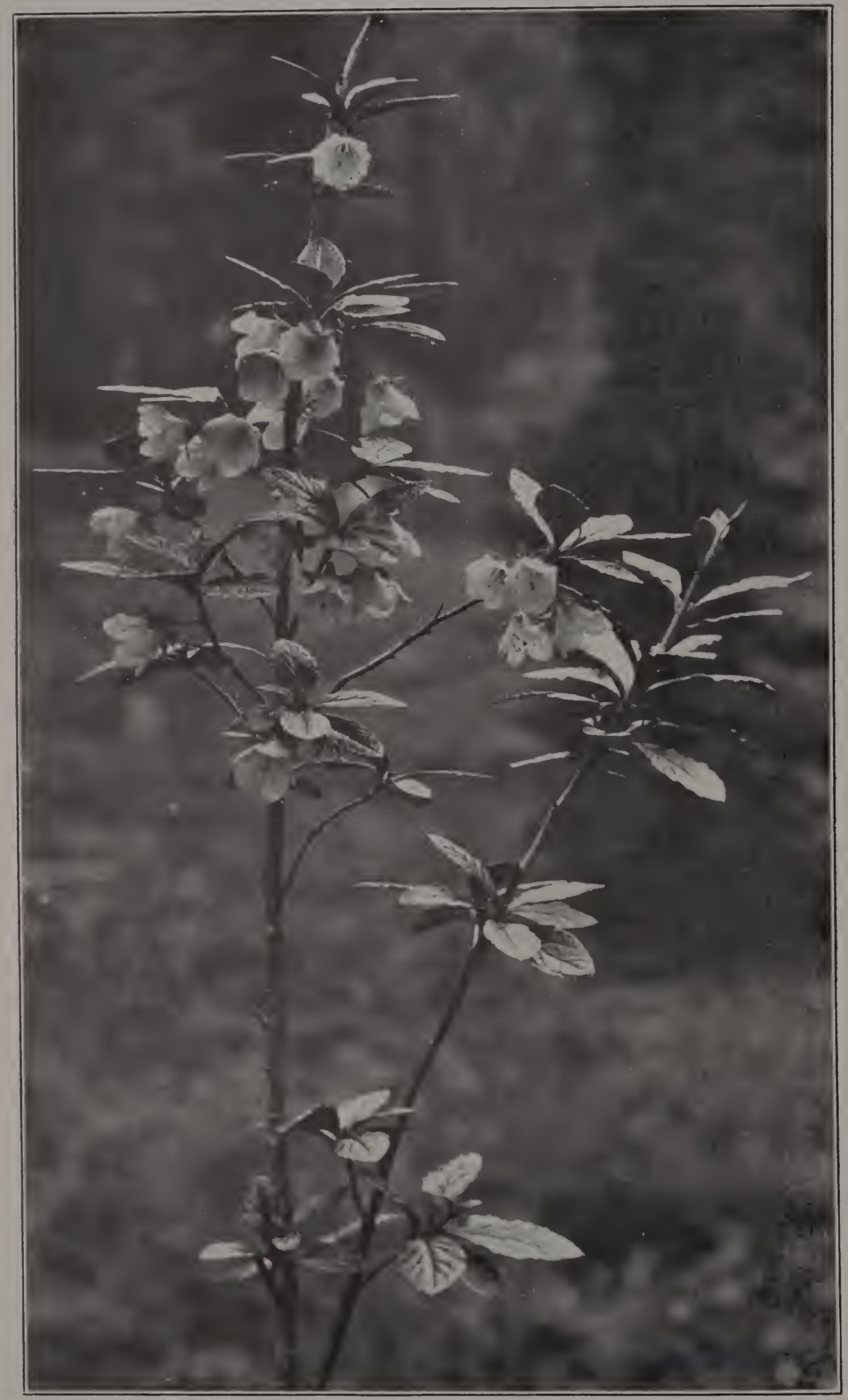

FIG. 9.-White rhododendron (Rhododendron albiflorum).

Color of flower, white or greenish white; height of plant, 4 to 6 tect; blooms July and August. Photograph by $\mathrm{A}$. HI. Barnes. 
ever, to be poisonous to sheep and other animals. The mountain ash, Sorbus occidentalis, has large flat clusters of rather small white flowers and compound leaves. This is also much admired in the late

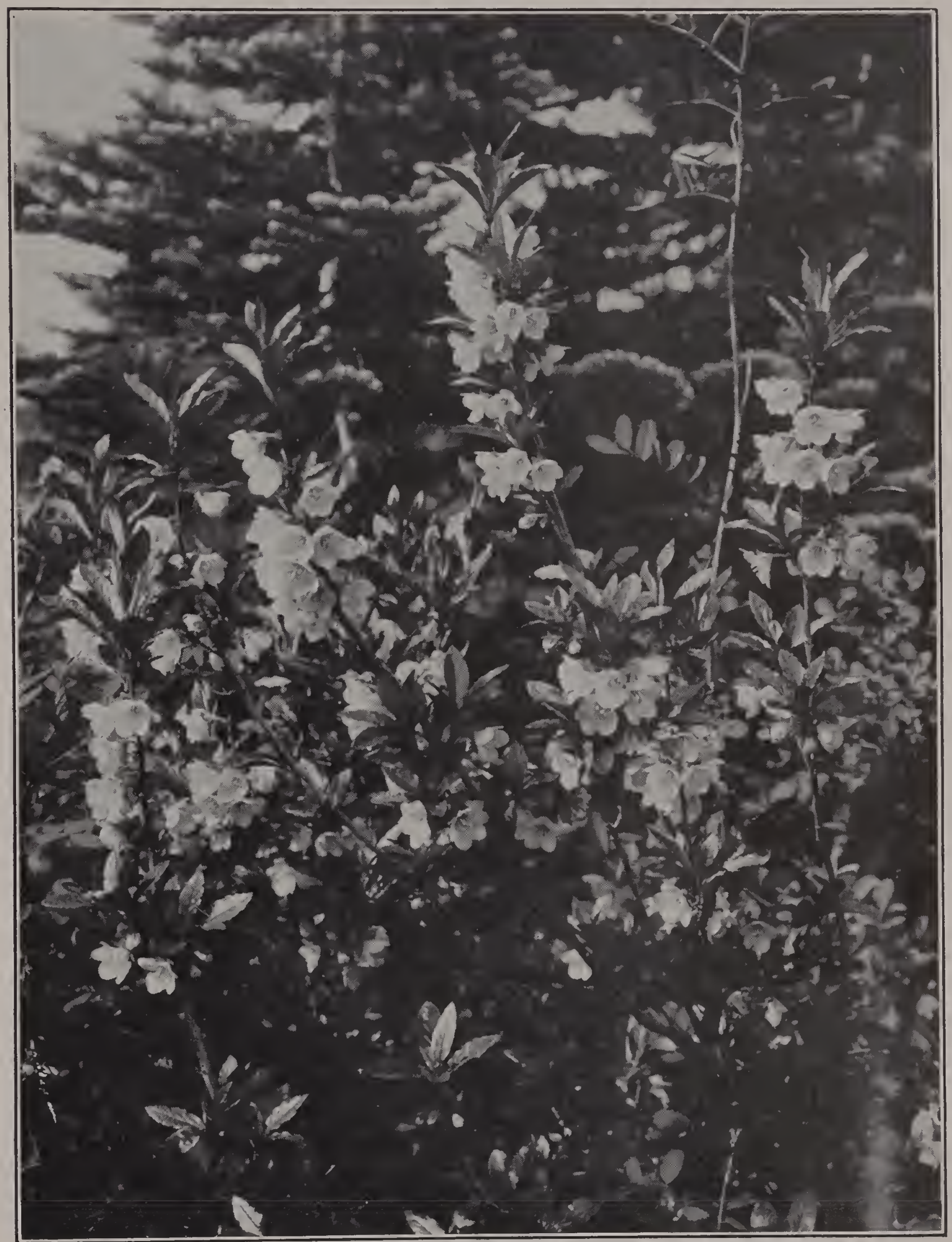

FJG. 10.-White rhododendron (Rhododendron albiflorum).

Color of flower, white or greenish white; height of plant, 4 to 6 feet: blooms July and August. Photograph by Asahel Curtis.

fall and early winter because of its bright red berries which hang on the shrub for a long time unless devoured by the birds. The camp robbers and Clark's crow see that these berries do not stay on too long. 
The ovate-leaved salal, Gaultheria ovatifolia, occurs here among the moss. It is much smaller than its lowland relative and lies closer to the ground with its zigzag stem, ovate leaves, and small white urn-shaped flowers. These plants will leare a photograph of themselves on white paper when pressed, thus showing the presence of oil. In case of a forest fire both species of these plants take fire readily because of their oily nature and do much to increase the rapidity of

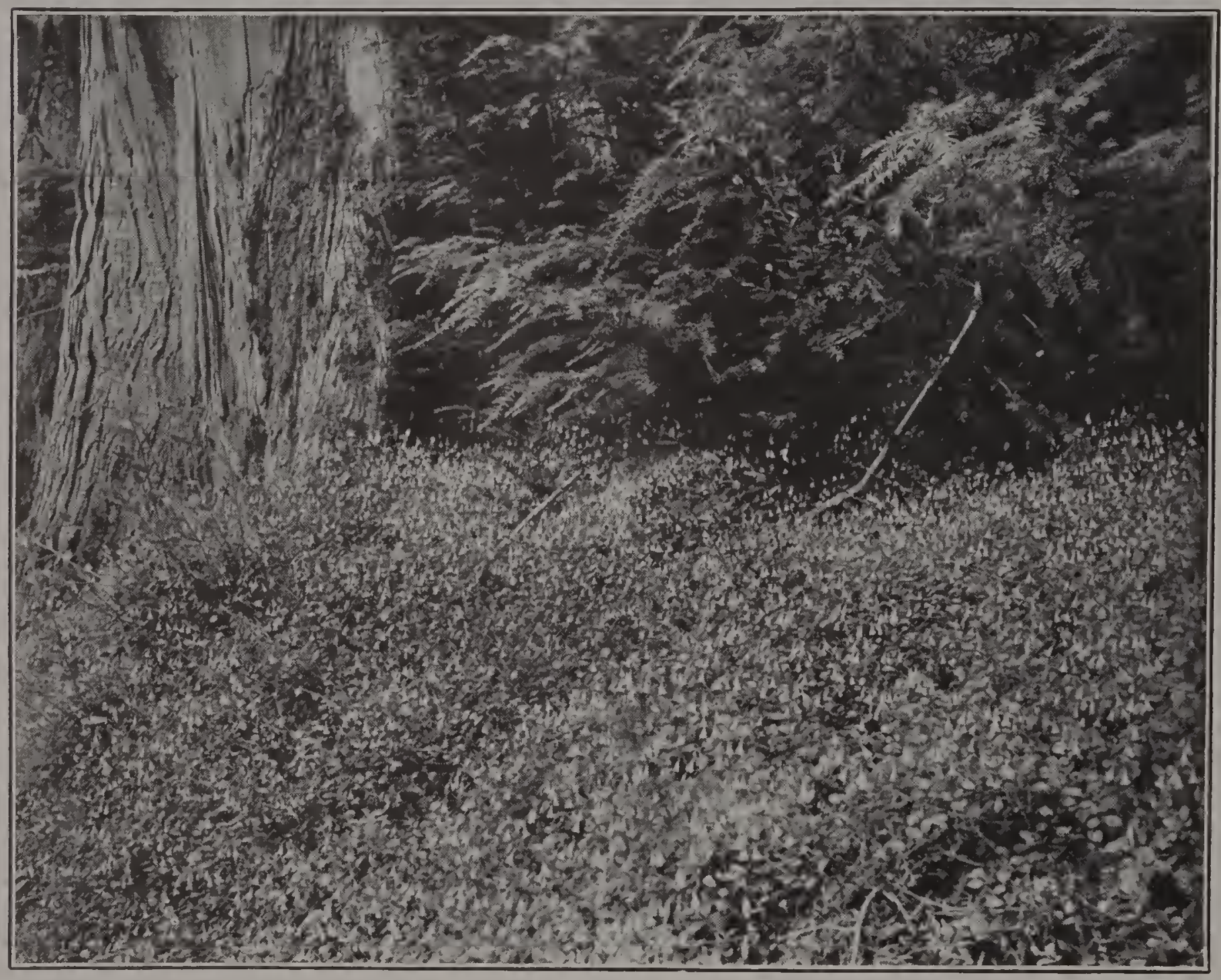

FIg. 11.-Twin-flower (Linnaer americana.)

Color of flower, pink; plant trailing on the ground, etc.; klooms July and A ugust.

Photograph by $\Lambda$. H. Denman.

the fire orer the forest cover. 'They burn with an explosive crackling sound.

The twin-flower, Linnaea americana (fig. 11), is one of the most dainty and graceful of our trailing vines. Trailing rines are rather rare in this region as are plants with much fragrance. This plant can be detected by its odor long before it is seen. It has two graceful, pink bell-shaped flowers near the end of each branch. These vines grow in radiating lines and its connection with the honeysuckle family can be seen both by its creeping' stems and its fragrance. 'This plant is named in honor of Limmæus, the great Swedish botanist. It has a wide range extending across the continent. Locally, it extends from sea level to about 4,000 feet, reaching its highest derelopment about 2,800 feet. 
The squaw-grass, Xerophyllum tenax (fig. 12), is perhaps the plant that attracts the greatest attention. It receives its common name from the fact that the Indians use it in making their baskets. It has other popular names, such as mountain lily, elk-grass, bear-grass, etc.

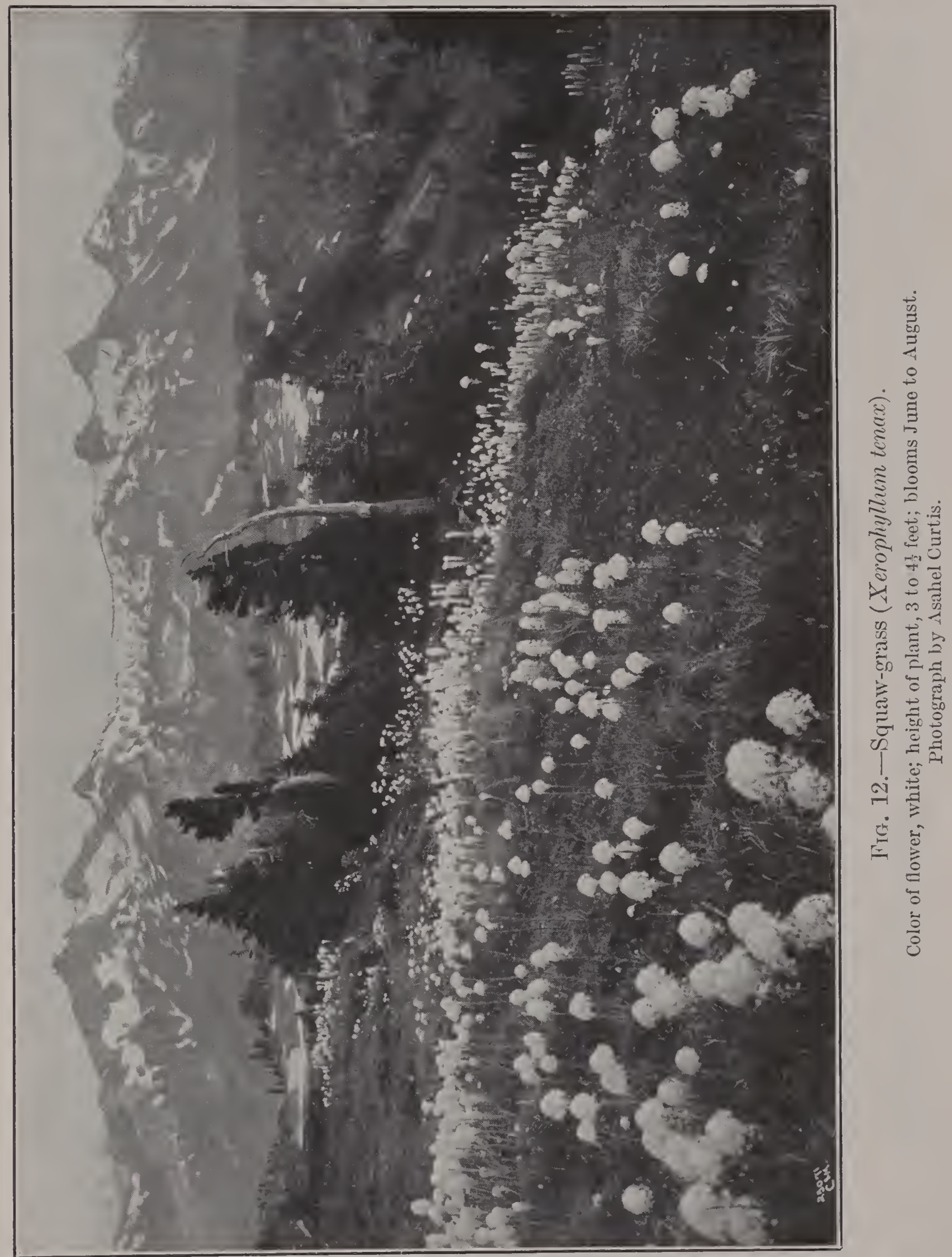

It may be recognized by its dense mat of coarse grass-like leares and flower stalk about 3 fect high with raceme of beautiful creamy white flowers. In the early stages of development the flowers are crowded into a conical cluster at the top which gradually lengthens 
out until the stalk is nearly uniform with flowers on all sides. 'This, like the twin-flower, is very fragrant. In places where the trees are small this plant grows abundantly, generally in volcanic ash soil.

With it may be found the pyrolas, pipsissewas, and mertens' coral root, Corallorhiza mertensiana. The latter may be recognized

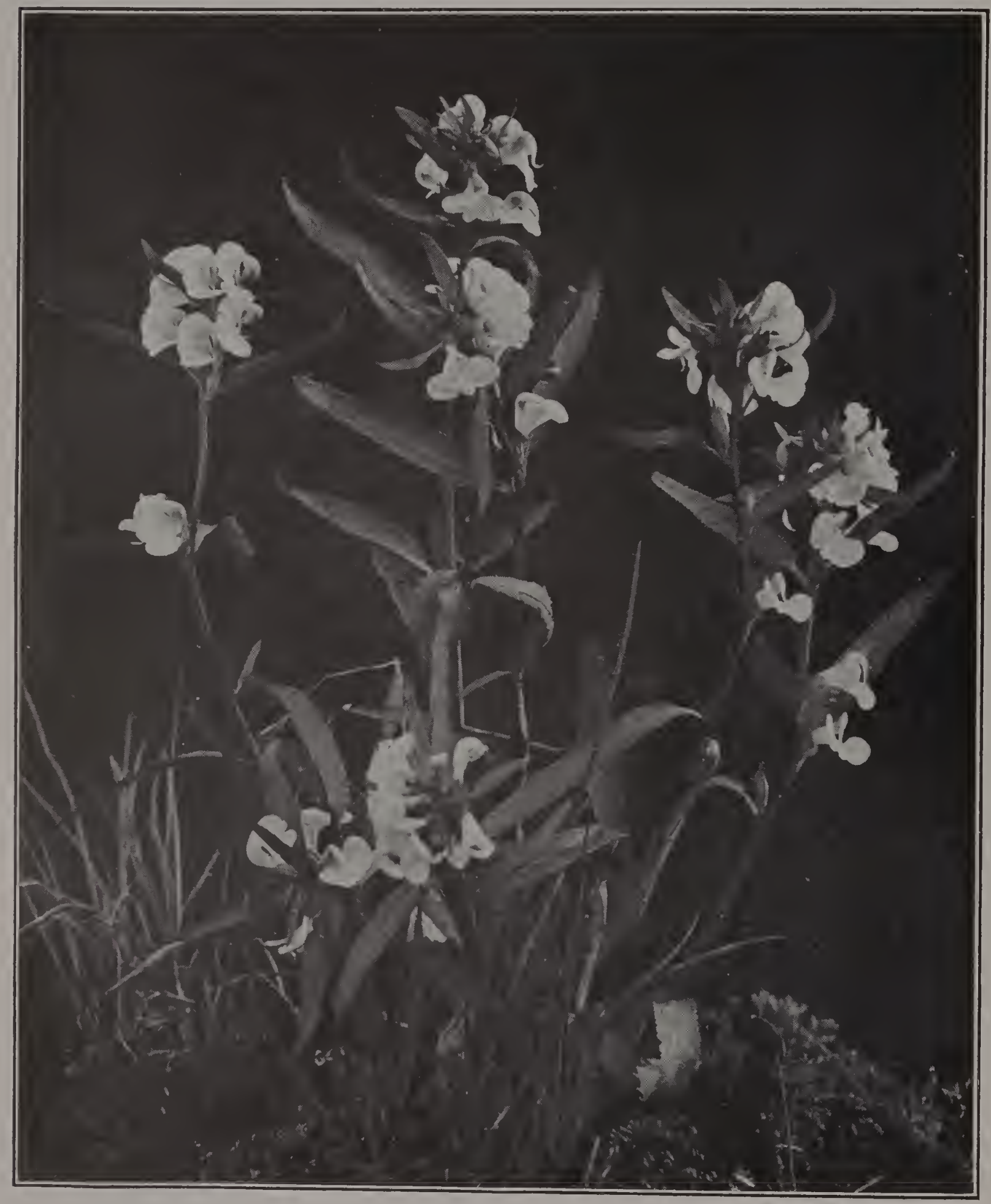

FIg. 13.-Common lousewort (Pedicularis racemosa).

Color of flower, pinkish white; height of plant, 5 to 8 inches; blooms July and $A$ ugust. Photograph by $\Lambda$. H. Barnes.

by its leafless stalk, coral-like roots, and strange pink flowers in racemes. This saprophyte grows in clusters like the other coral roots and is a characteristic plant of this region. Sereral of the leafless plants mentioned in the first zone extend well up through the second. 
The common lousewort, Pedicularis racemosa (fig. 13), may be known by its tendency to lean over, its lanceolate leaves, and pinkish-white flowers. It usually grows in radiate clusters.

Sweet-after-death, Achlys triphylla, is common through these woods, extending up from sea level. It may be known by its spike of small white feathery flowers and the leaf in three cuneate sections. This has several other common names, as sweet-clover, vanilla leaf, smelling: leaves, etc. In the cities it is collected in bunches and sold on the streets under the name "smelling leares," as the leaves become more fringrant as they dry.

Trautvetteria grandis has no common name. It has delicate white feathery blossoms in corymbs and maple-like leaves. It belongs to

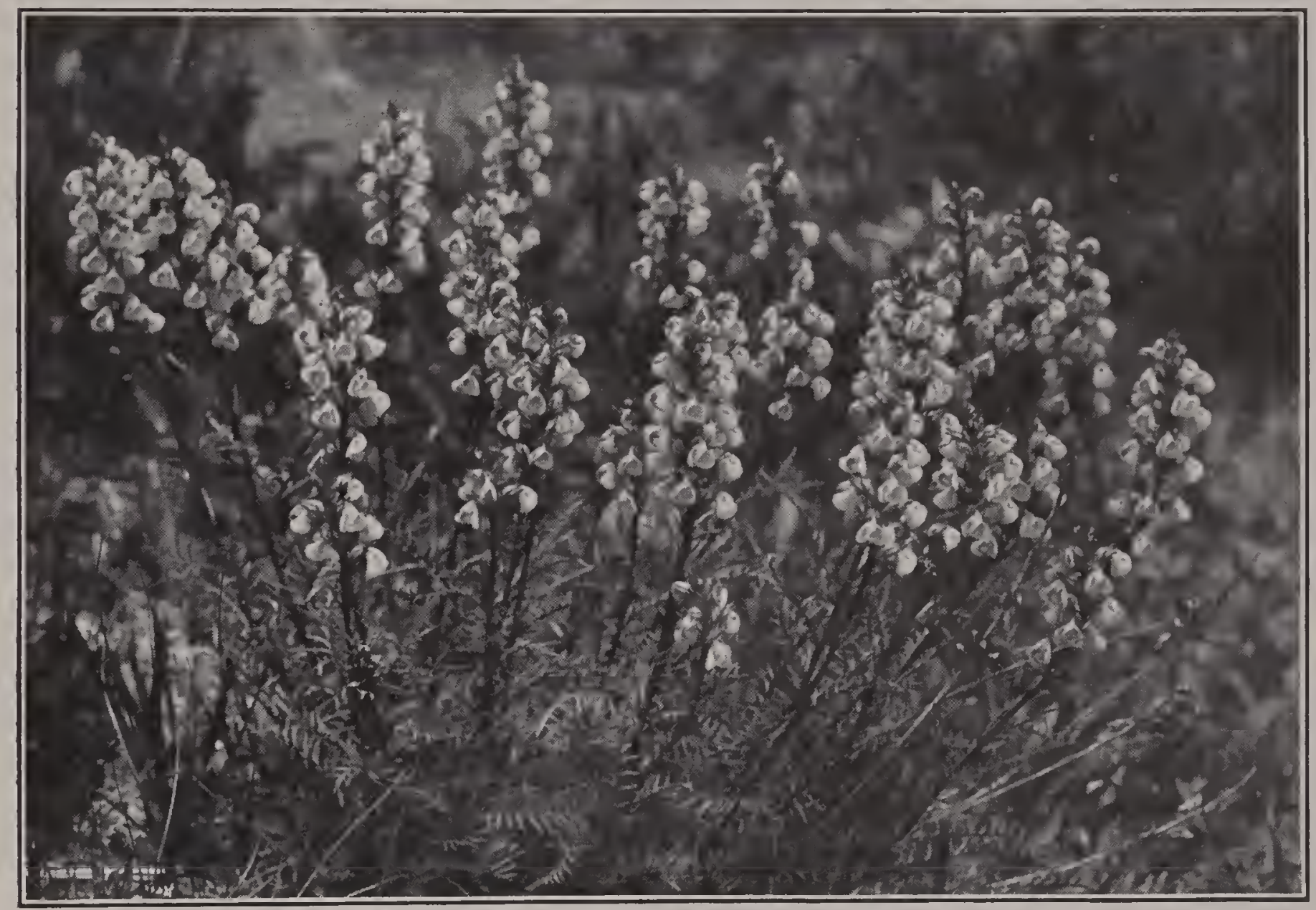

FIG. 14.-Pedicularis contorte.

Color of flower, light yellow; height of plant, 6 to 9 inches; blooms July and August.

Photograph by $\Lambda$. H. Barnes.

the buttercup family and like most plants of that group it is quite ornamental. Many questions are asked about it.

The bird's-foot bramble, Rubus pedatus, is recognized by its long trailing vine, compound leaves, and strawberry-like flowers. It covers the ground in many places, and the pack animals eagerly feed on it, when they have an opportunity. The snowy bramble, Rubus nivalis, may be recognized by its hard glossy simple leaves, red berries, and red flowers. It is never found in such abundance as the above. Somewhat similar to the bird's-foot bramble is Rubus lasiococcus, but this has simple leaves and extends to a greater altitude 
Along the rivers where there is an abundance of light may be found a strange assembly of plants. Many are washed down from above and have rooted in the scanty soil. Those not adapted will sooner or later die, while those like the alder and willow form thickets and grow luxuriantly, thus giving protection to other plants. In this way the river channel is often changed. Luina hypoleuca, a beautiful composite plant with glossy oval leaves, white underneath, is found on the old river channels at Longmire Springs and much lower down. This grows on the perpendicular cliffs near the glaciers. The plants themselves may be washed down and take root when stranded, or seeds may be carried by the river and lodge on the gravel bars and germinate, producing the species at a lower altitude. Perhaps both methods are successful in the production of these river bottom strangers, many of which compete successfully with those plants common to that region. Maples, cottonwoods, alders, and willows are the arborescent plants usually found here. These river-bar waifs are usually those which grow along. streams higher up or on perpendicular cliffs above the streams.

There are several extensive areas swept by fire just below the meadows. The "pearly everlasting" seems to hare taken possession of some of these, while the fireweed and a combination of other plants have a firm hold on other areas. These burnt areas are strewn with fallen logs and old erect snags, which are tottering and ready to fall. After every windstorm there is a new addition to the prostrate forms. This is especially noticeable along the roads, trails, and telephone lines. Some of these aroas were burned 20 years ago. Still there is littlo progress toward reforestation. The areas near the forest receive the seed and new trees start up, while those more remote have made little headway and still present desolate scenes with their blighted crop of "ghost trees" and scattered logs. The huckleberries, mountain ash, and the white rhododendron usually grow in great profusion and ripen their fruit in excellent condition.

\section{THE - THIRD ZONE.}

The lower part of the third zone or the first meadows reached are usually moist and covered with tall grasses and sedges. The sedges are more abundant and can be recognized by their triangular stems and coarse appearance. In the early part of the season these grassy places are covered with a minute form of a swamp riolet. This grows so near the ground that it is often orerlooked.

The shooting star, Dodecatheon jeffreyi (fig. 15), is one of the most conspicuous. It his a rosette of oblanceolate leares and peculiar shaped flowers, resembling those of the cyclimen, which is a near relative. 
The purple aster, Eucephalus ledophyllus (fig. 16), is frequently found here. It has tall leafy stems, leaves pubescent on the underside. The ray flowers are pinkish purple. It grows so abundantly that in favored localities the ground is covered with the plants

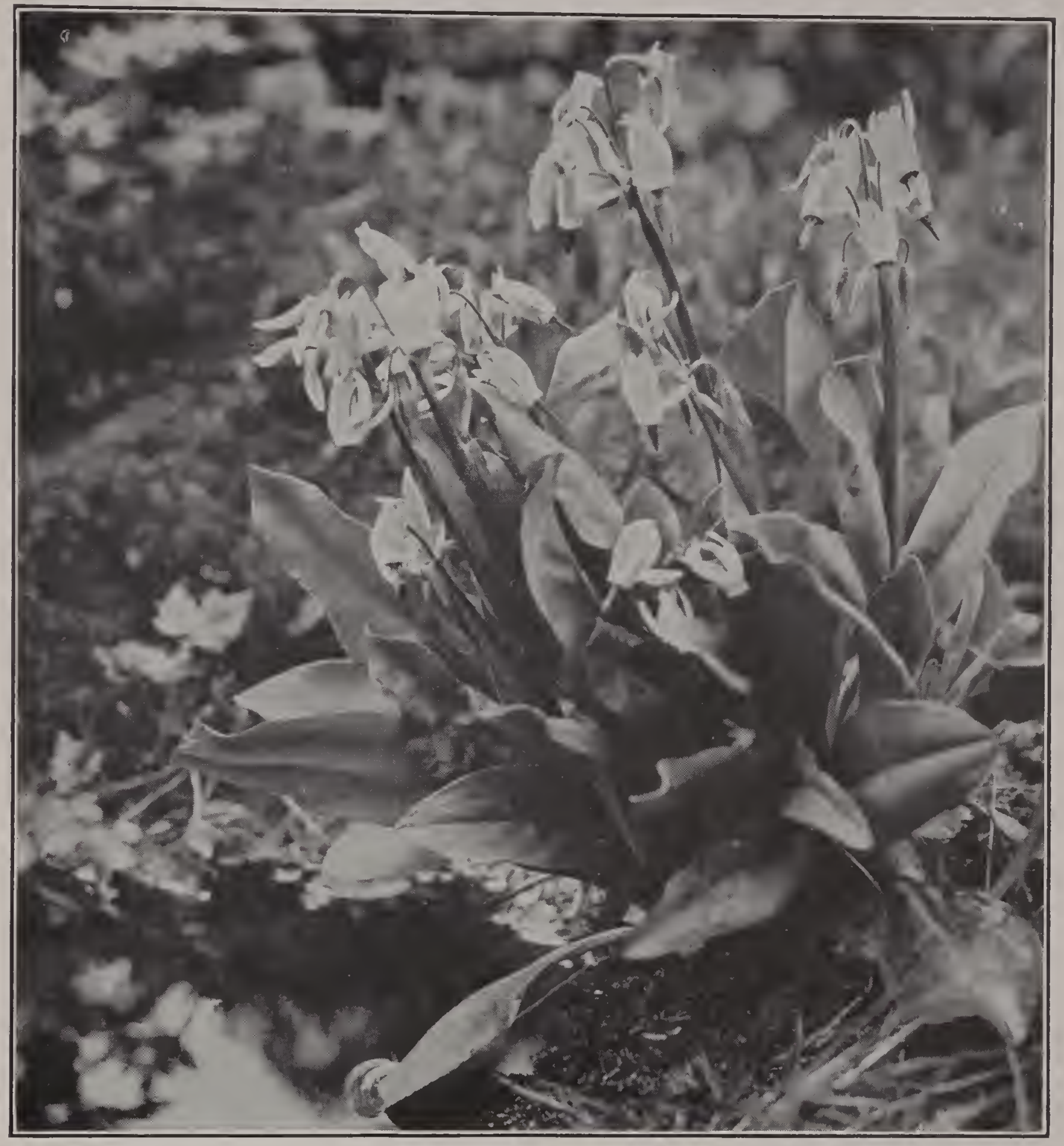

FIG. 15.-Shooting star (Dodecatheon jeffreyi).

Color of flower, pink; height of plant, 6 to 10 inches; blooms July and August. Photograph by $\Lambda$ sahel Curtis.

with head touching head, swaying in unison to the least breath of wind.

Here, also, grows the elephant's trunk, Pedicularis groentandica surrecta. It has pinnately parted leaves, coiled beak, and dull purple flowers. The peculiar resemblance of its beak to the trunk of an elephant gives it its popular name. The chief interest in this plant lies in its oddness and not in the brilliancy of its color, like those just mentioned. The cotton grass, Eriophorum polystachyon, 
grows abundantly here, with its long slender stalk, bearing a white cotton-like tuft on the summit. Sometimes this plant seems to take complete control of small areas, but more of ten grows mixed with other plants. The rosy spiraea, Spiraea densiflora, is a wellknown little shrub bearing dense clusters of small red flowers on numerous short slender stems. In similar situations in the Olympic,

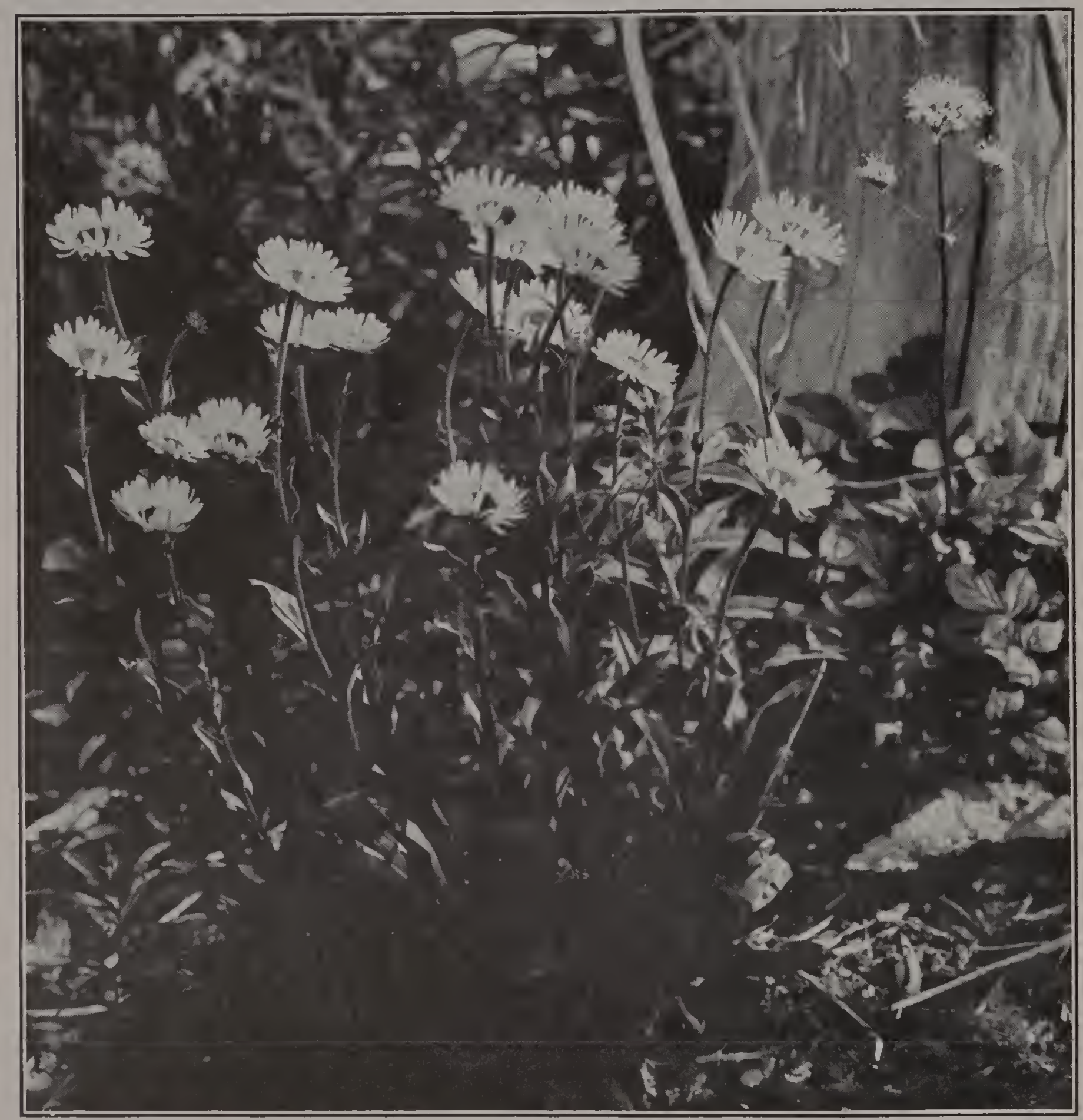

FIG. 16.-Purple aster (Eucephalus ledophyllus).

Color of flower, pinkish purple; height of plant, 1 to 2 feet; blooms July to September.

Photograph by Asahel Curtis.

Mountains the Douglas spiraea of the lowlands grows with the above, but this combination has not been seen here. Salix commutata, the common alpine willow, grows abundantly in these low meadows and bogs, and is in bloom about the 1st of July. There are few plants in bloom on the mountain before that time, unless the season should be unusually early. Leptarrhena, Saxifraga, Mitella, and Erythronium are some of the other genera composing 
the spring crop. Later the grass of Parnassus, Parnassia fimbriata, a beautiful plant with reniform leaves and white fringed petals adorn these moist areas, coming up here and there among the asters, erigerons, and arnicas about the latter part of August in time to salute the last visitors of the season.

Above these moist meadows are more extensive grassy areas with better soil and well drained. Here are found the real natural flower gardens of the mountain, surpassing perhaps in beauty of color, number of species, and luxuriance of growth any other alpine region of the world.

On passing through a dense cluster of alpine trees and emerging for the first time into one of these "gardens" one of the most noted of the botanical visitors to the park last summer stopped and repeated the word "wonderful! wonderful! wonderful!" This was the verdict of a man whose long and successful life has been devoted to botanical research not only in his own fatherland but in nearly every country of the world. He stood until his companions were nearly out of sight, hastening on to reach the hotel in time for lunch, but he breathed in the fragrance of the flowers and scanned the delightful vista before him unmindful of mere bodily wants.

A satisfactory description of a natural flower bed has not come to the writer's observation nor does he expect to write one now. If by means of this article more people shall be brought in touch with the mountain and its wonderful flora he will be satisfied. These flower beds must be seen and their fragrance inhaled before a full comprehension of them can be realized. The more one sees them, the more does he realize their infinite beauty and the full significance of the spiritual lessons which these floral emblems teach.

By numerous photographs and brief descriptions some idea of these natural flower beds may be obtained. In the early spring the white mountain deertongue, Erythronium montanum (fig. 17), is by far the most abundant and conspicuous, thrusting its leaves and flowers up through the snow. Avalanche lily, adder's-tongue and dog's-tooth violet are other popular names for this plant. It has two lanceolate leaves with sinuous edges without dark blotches and several flowers in the form of a raceme.

Suksdorf's buttercup, Ranunculus suksdorfii (fig. 18), is an almost constant companion of the deertongue. Though not as successful in making its way through the snow, it is in bloom near the snowbank soon after the snow has melted from it. This is the only buttercup occurring with the mountain deertongue so there can be no confusion, though it is often confused with Potentilla flabellifotia (fig. 19), which belongs to the rose family. The latter can be identified by its small bracts between the sepals while the sepals of the buttercup are rolled 
back and fall off early. The potentilla is also larger than the buttercup and does not bloom so near the snow.

The western anemone or Pulsatitla occidentalis (figs. 20 and 21) is also ready to put forth its blossoms with the buttercup. This is the only anemone found near the snow. It has large lavender flowers with leaves still in the bud until the floral organs drop off. Then the fincly dissected leaves unfold and the plumelike heads de-

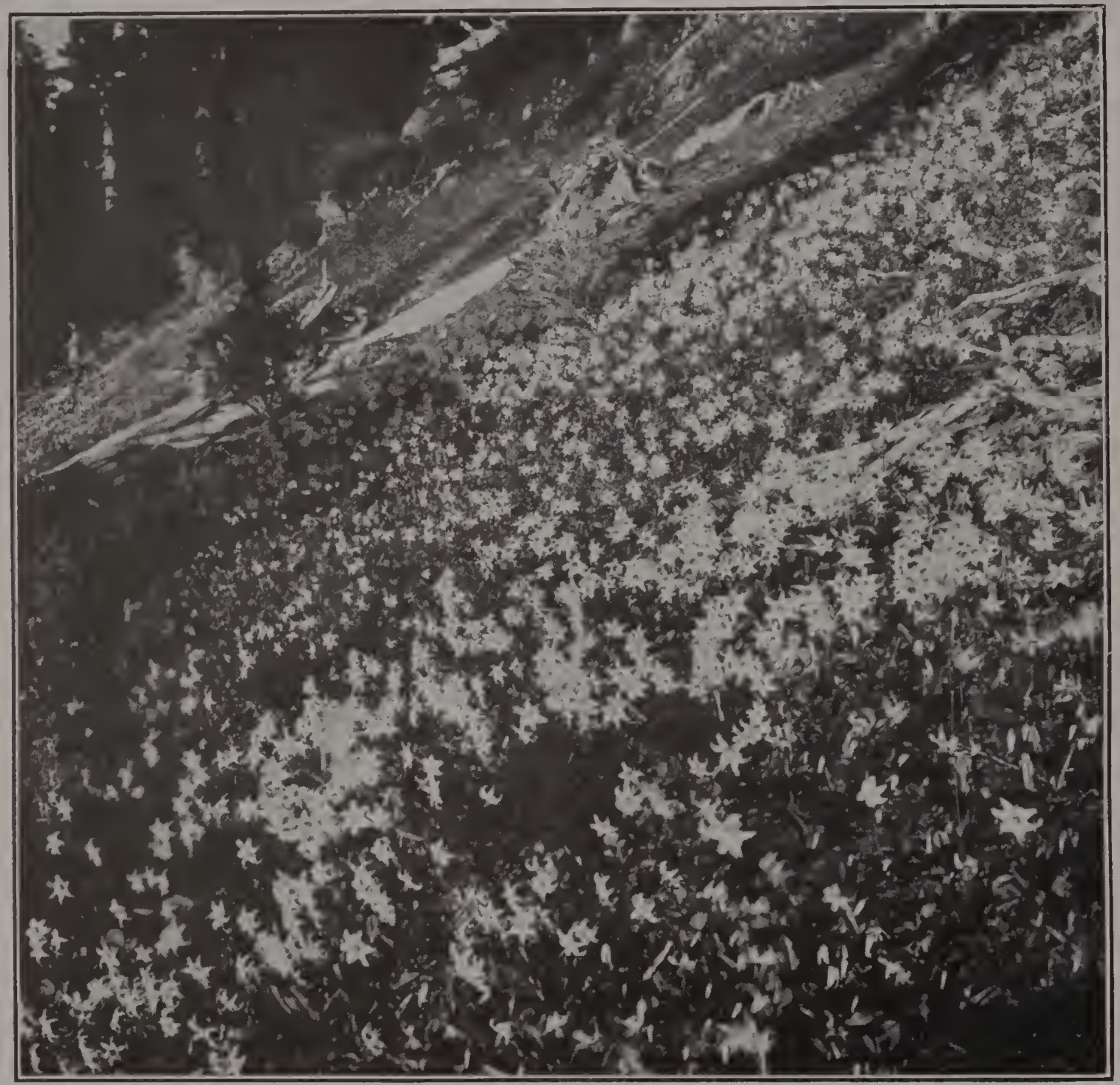

FIG. 17.--Deer tongue (Erythronium montanum).

Color of flower, white; height of plant, 7 to 15 inches; blooms July and A ugust. Photograph by Asahel Curtis.

velop, showing the feathery appendages of the seeds. It is greatly admired both in flower and fruit.

After these hardy pionecrs have held undisputed sway for a week or two the other plants spring forth in rapid succession transforming the bare ground and the site of the dust-covered snow bank into a veritable flower bed. The season is short. Everything moves rapidly. As the wecks come and go so does the succession of plants 
come and go, changing as by magic; in flower one week and in seed the next. 'The most conspicuous of the later plants is the valerian, Valeriana sitchensis (fig. 22). This is also wrongly called the mountain heliotrope on account of its small pinkish white flowers in cymes, resembling the common garden heliotrope though having no relationship. It is a tall plant with a strong characteristic odor; the leaves are pinnate, the upper leaflet being by far the largest. It is usually one of the tallest plants in these flower beds in the neighborhood of 5,500 feet and grows abundantly, beginning to bloom in

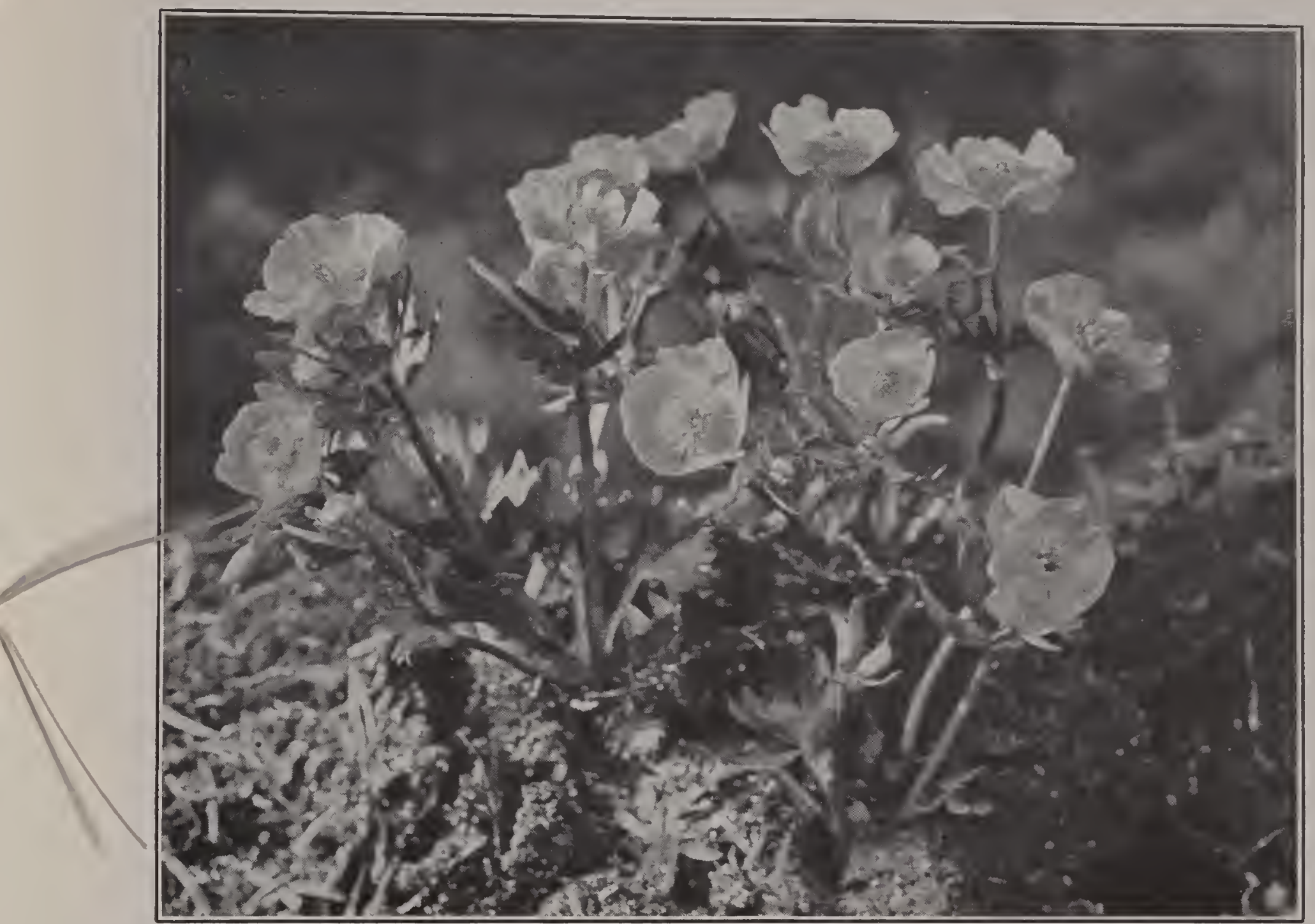

FIG. 18.-Suksdorf's buttercup (Ranunculus sulisdorfii).

Color of flower, yellow; height of plant, 5 to 12 inches; blooms July and A ugust.

Photograph by A. H. Bames.

the early part of July. It continues to bloom until the middle of August or the first of September.

Mertensia Taevigata (fig. 23) is another plant between 2 and 3 feet high with raceme of blue-purple flowers and thin ovate leaves. The Arctic lupine, Lupinus subalpinus (fig. 24), grows with the above, though it is not so tall, but is really more conspicuous because of its many radiate flower stalks with long racemes of pealike purple flowers and palmately compound leaves. Polemonium pulchellum (fig. 25) is another handsome plant with pinnate leaves and blue flowers in cymulose clusters. Cusick's speedwell, Veronica cusickii, 
is a small plant about 3 to 6 inches high with opposite ovate leaves and raceme of blue-violet flowers. It is a very abundant plant at an altitude of about 5,000 to 6,000 feet on all sides of the mountain. What it lacks in size it makes up in abundance and does

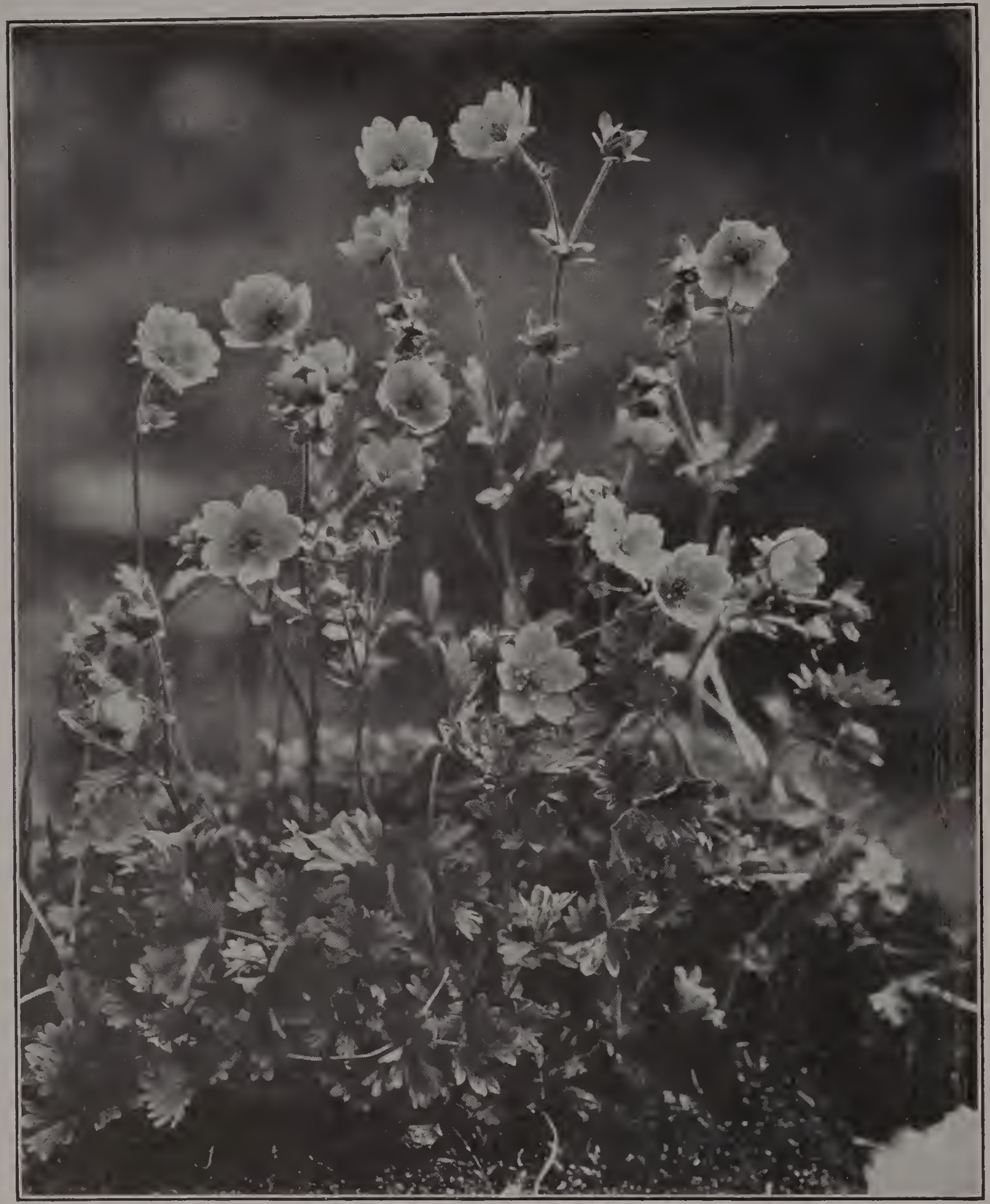

Fig. 19.-Potentilla flabellifolia.

Color of flower, yellow; height of plant, 8 to 16 inches; blooms July and August.

Photograph by A. II. Barnes.

much underneath the mertensias, lupines, and polemoniums to render prominent the blue color in the flower beds. The Indian paint brush, Castilleia oreopola, attracts more attention, perhaps, than any other plant of its size on the mountain, because of its bright 


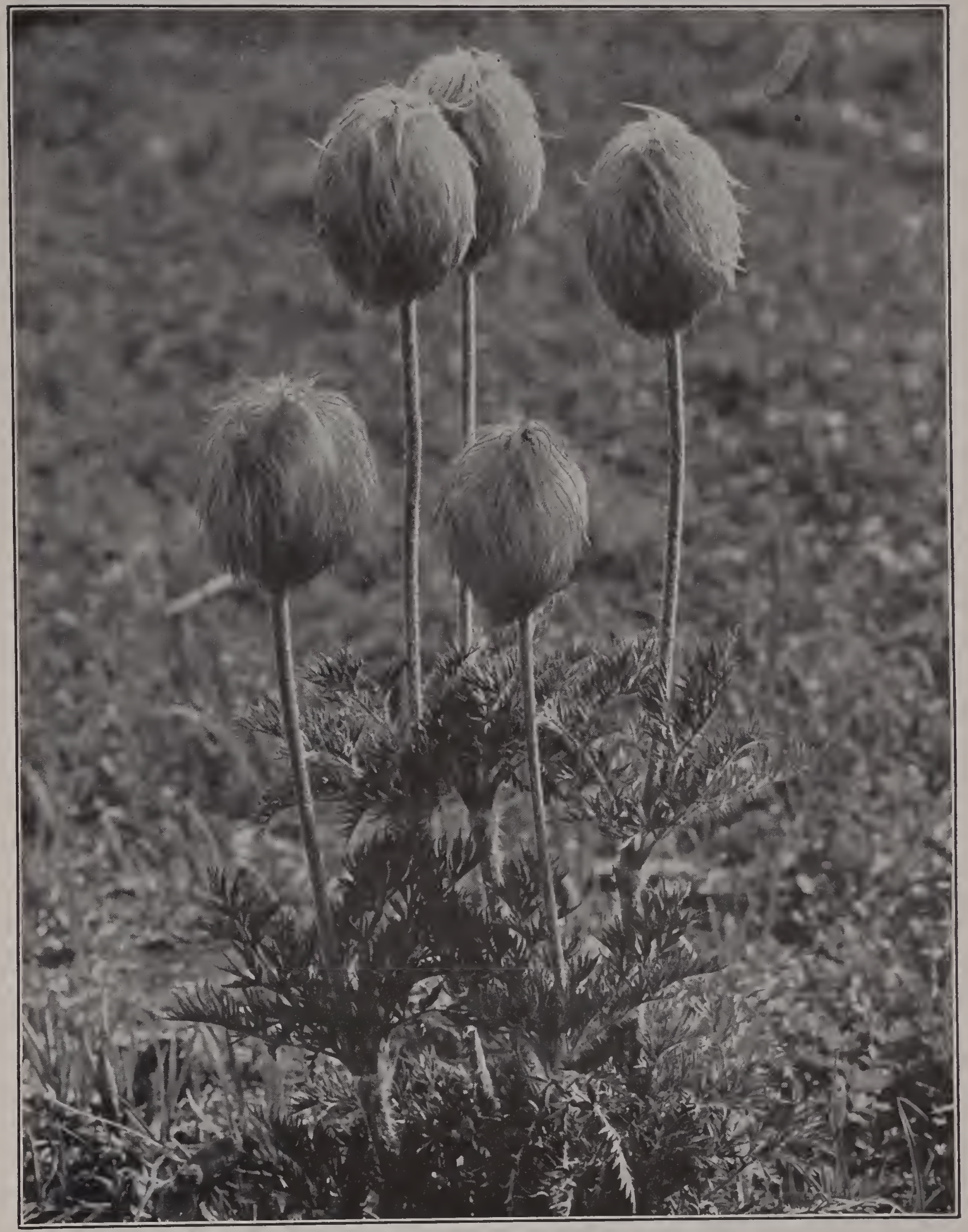

FIG. 20.-Western anemone in fruit (Pulsatilla occidentalis).

Color of flower, lavender; height of plant, 10 to 18 inches; blooms July and August.

Photograph by 1. H. Barnes. 
red or purplish red color and radiate clusters. These red clusters appear in well-balanced groups throughout these extensive flower beds, harmonizing with the blue, the white, and the yellow of other plants. Painted cup is another popular name for it. These common names are applied to any species of Castilleia in this vicinity. The red heather forms dense patches with its long shrubby stems usually leaning over to one side with its red bell-shape flowers.

Along the numerous streams may be found Lewis's monkey flower (fig. 26) with its rose-red two-lipped corolla. Here, too, may be seen

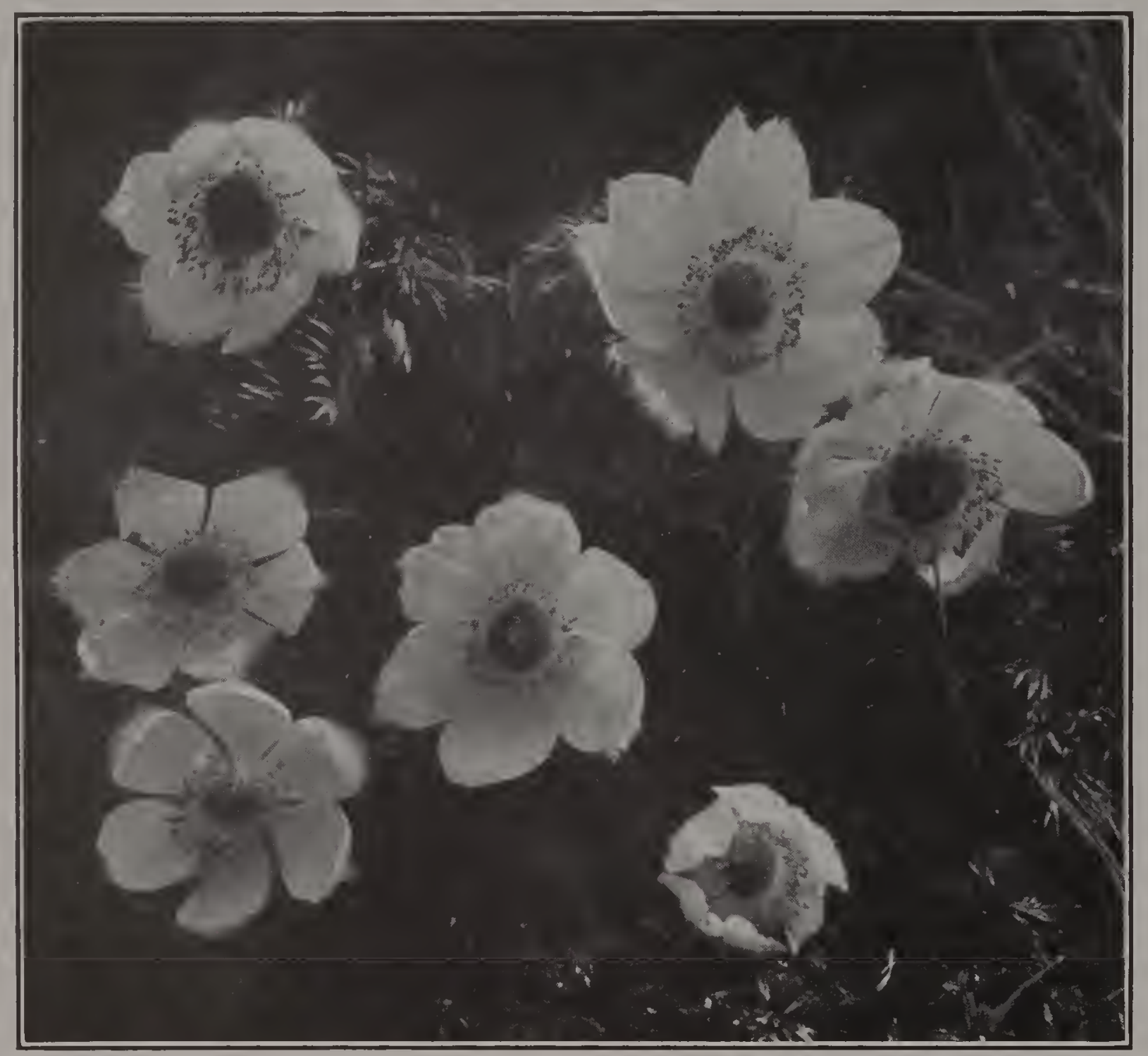

FIG. 21.-Western anemone in flower (Pulsatilla occidentalis).

Color of flower, lavender; height of plant, 10 to 18 inches; blooms July and August. Photograph by A. H. Barnes.

the rosy spiraea which continues up from the lower moist meadows. The spiraea and the monkey flower are always associated with moisture, while the Indian paint brush and red heather are not. These rills can often be traced in the distance by the bright rose-red flowers of Lewis's monkey flower and by the bright yellow of the alpine monkey flower, which loves the same habitat. Both species grow in dense masses and often cover the ground to the exclusion of other plants. The yellow fireweed, Epilobium luteum, flourishes best along the streams in the lower meadows. It may be known by its 


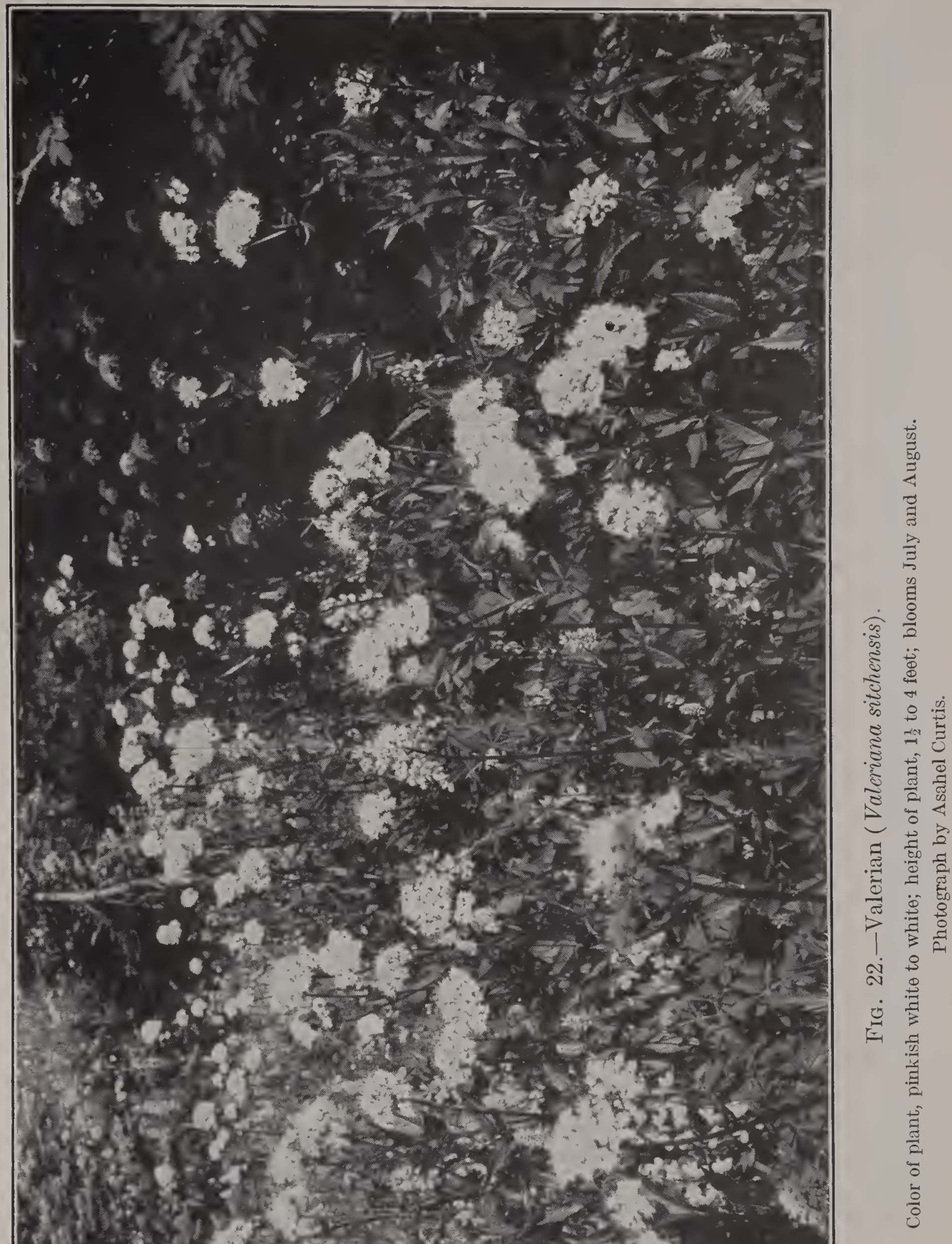

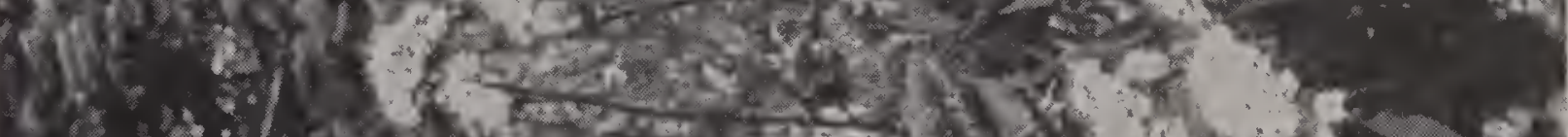

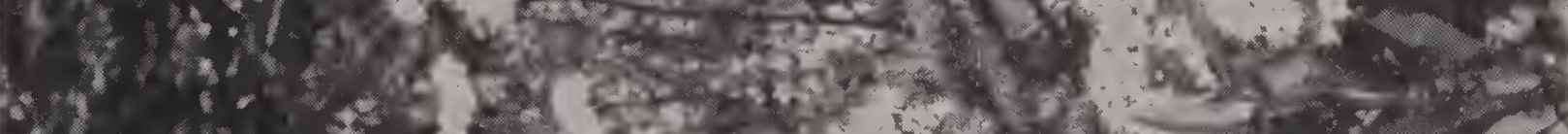

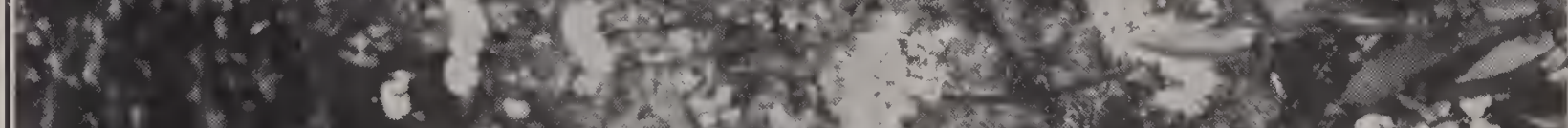
21 (n)

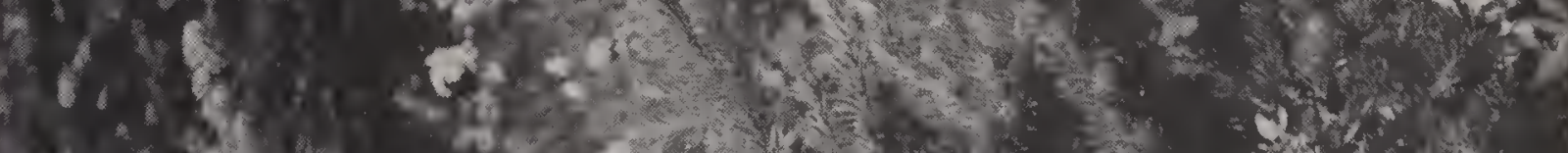

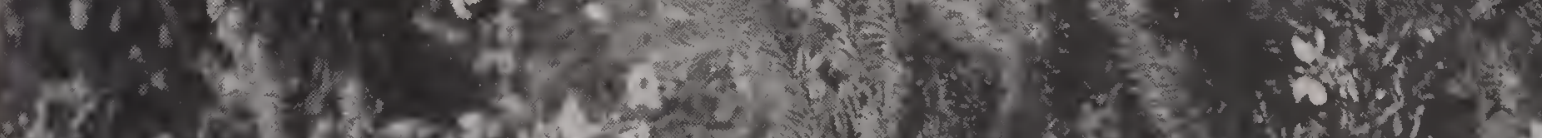

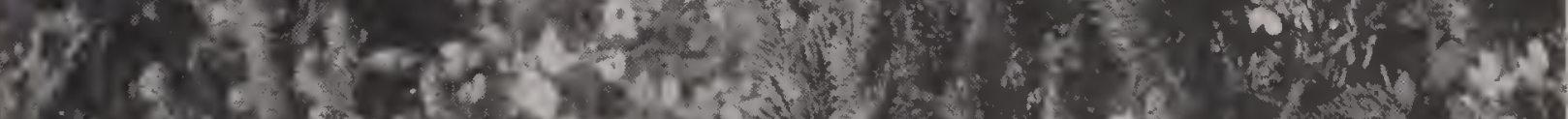

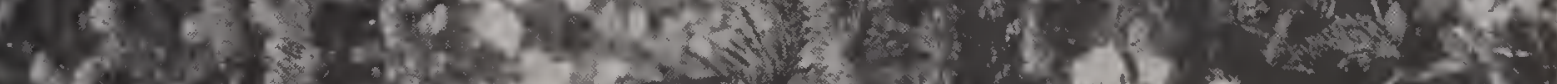

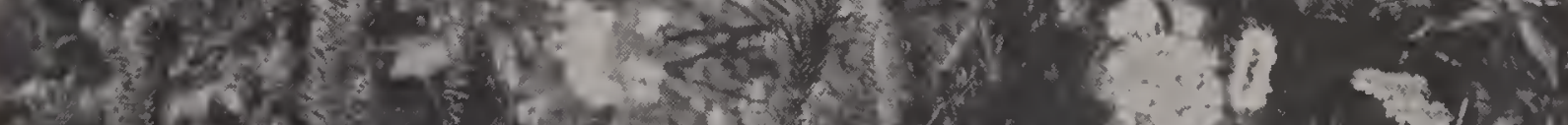

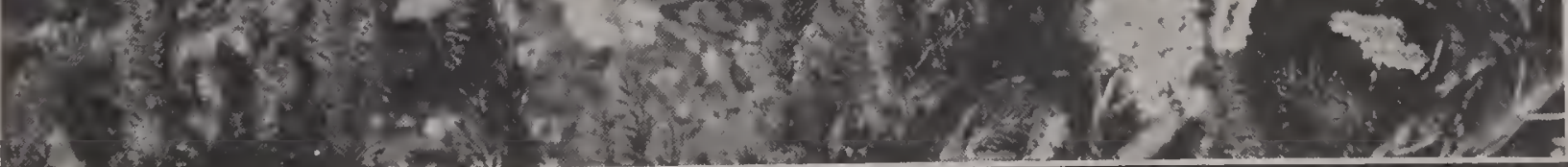


creamy yellow flowers and orate to lanceolate opposite leaves on a rather tall stem.

The mountain dock, Polygonum bistortoides (fig. 27), may be known by its lanceolate radical leaves and rather long, slender stem, bearing an oblong spike of small white flowers. 'This plant is very abundant

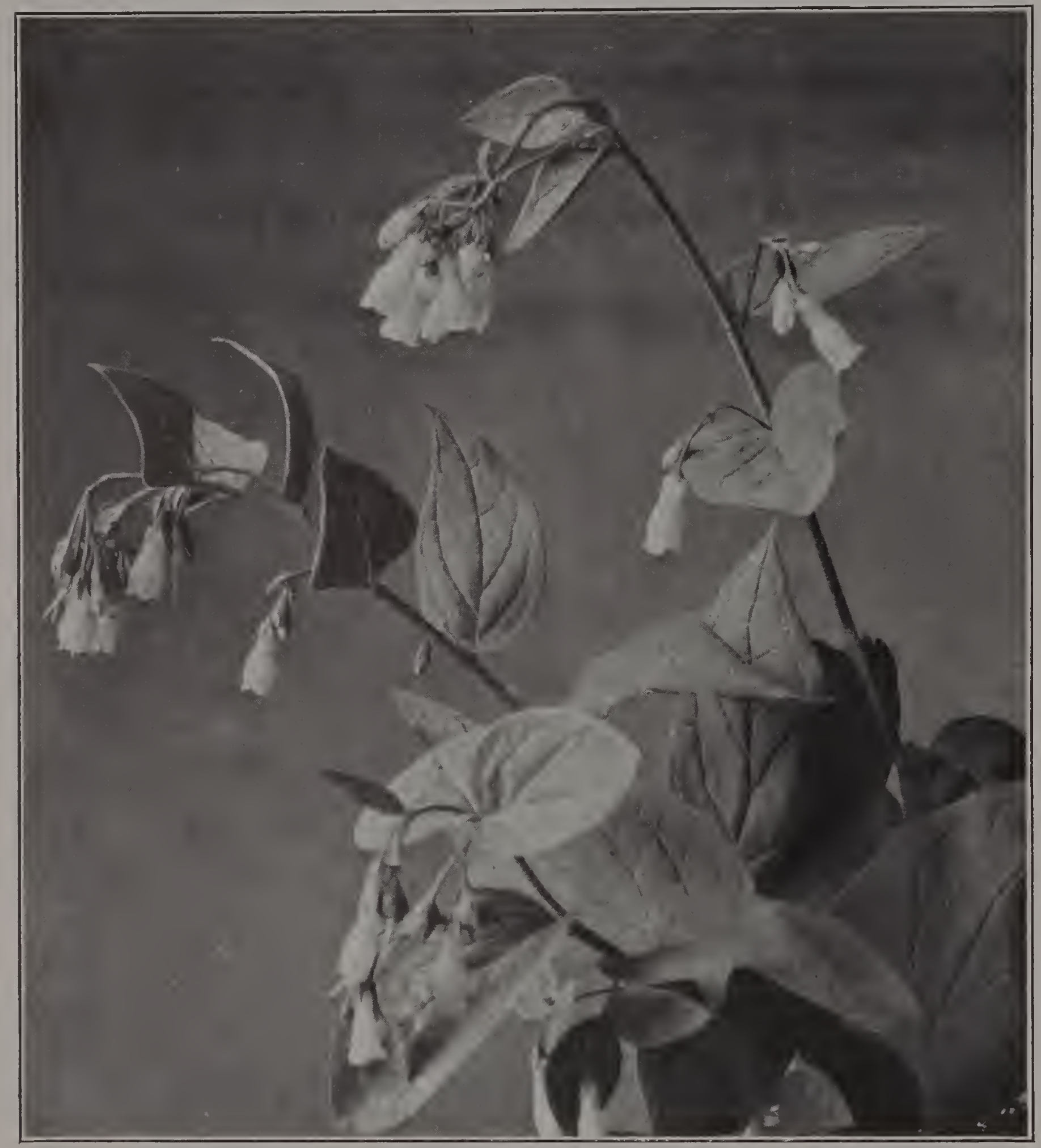

FIG. 23.- Mertensia laevigala.

Color of flower, blue to pinkish blue; height of plant, 2 feet; blooms July and August.

Photograph by A. H. Barnes.

and is easily swayed about by the wind, thus trying the patience of the flower photographer. It is nearly always associated with the valerian and the asters. There are several plants of the parsley family which may be recognized by their umbels of white or purplishwhite flowers. The "wild parsnip," Ligusticum purpureum, has finely dissected leaves and small whitish purple flowers. The mountain ash, 


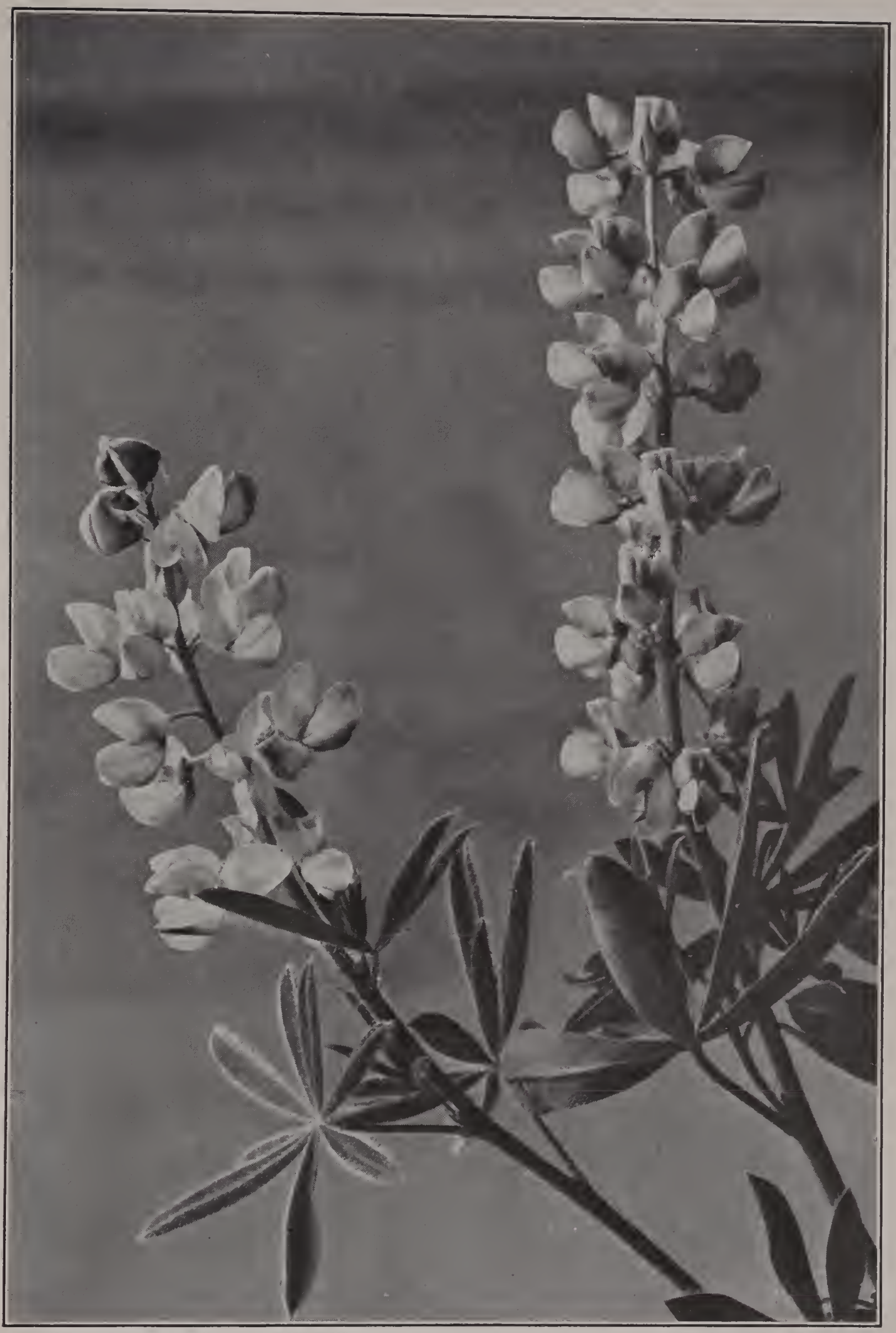

FIG. 24.-Arctic lupine (Lupinus subalpinus).

Color of flower, bluish purple; height of plant, 10 to 18 inches; blooms July and August. I'hotograph by A. H. Barnes. 
with its shrubby stem and large, flat flower clusters, often lends variety to the grassy slopes studded with numerous herbaceous plants. The mountain currant, Ribes acerifolium, also adds variety, especially near streams or in the shade of groups of trees, though its

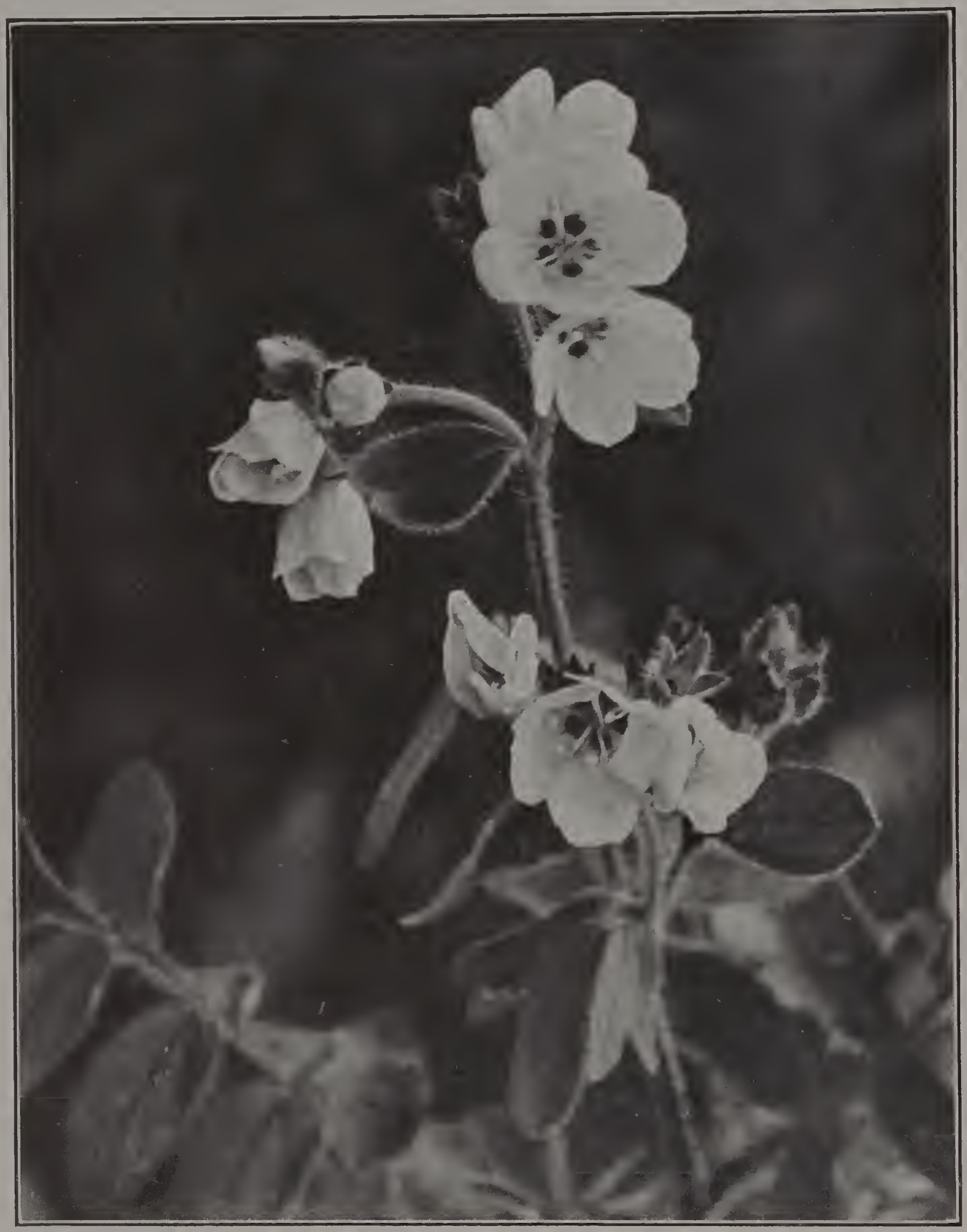

FiG. 25.-Polemonium pulchellum.

Color of flower, pale blue; height of plant, 8 to 12 inches; blooms July and August. Photograph by A. II. Barnes.

small green flowers are not conspicuous. The wild hellebore, Veratrum viride (see cover), forms dense clumps anywhere throughout these variegated slopes. Its tall herbaceous stem, rising 4 or 5 feet high, bear's drooping panicles of greenish-white flower's and very 
broad strongly veined and creased leaves. It is always a plant of marked interest to the tourist, not only on account of its color but on

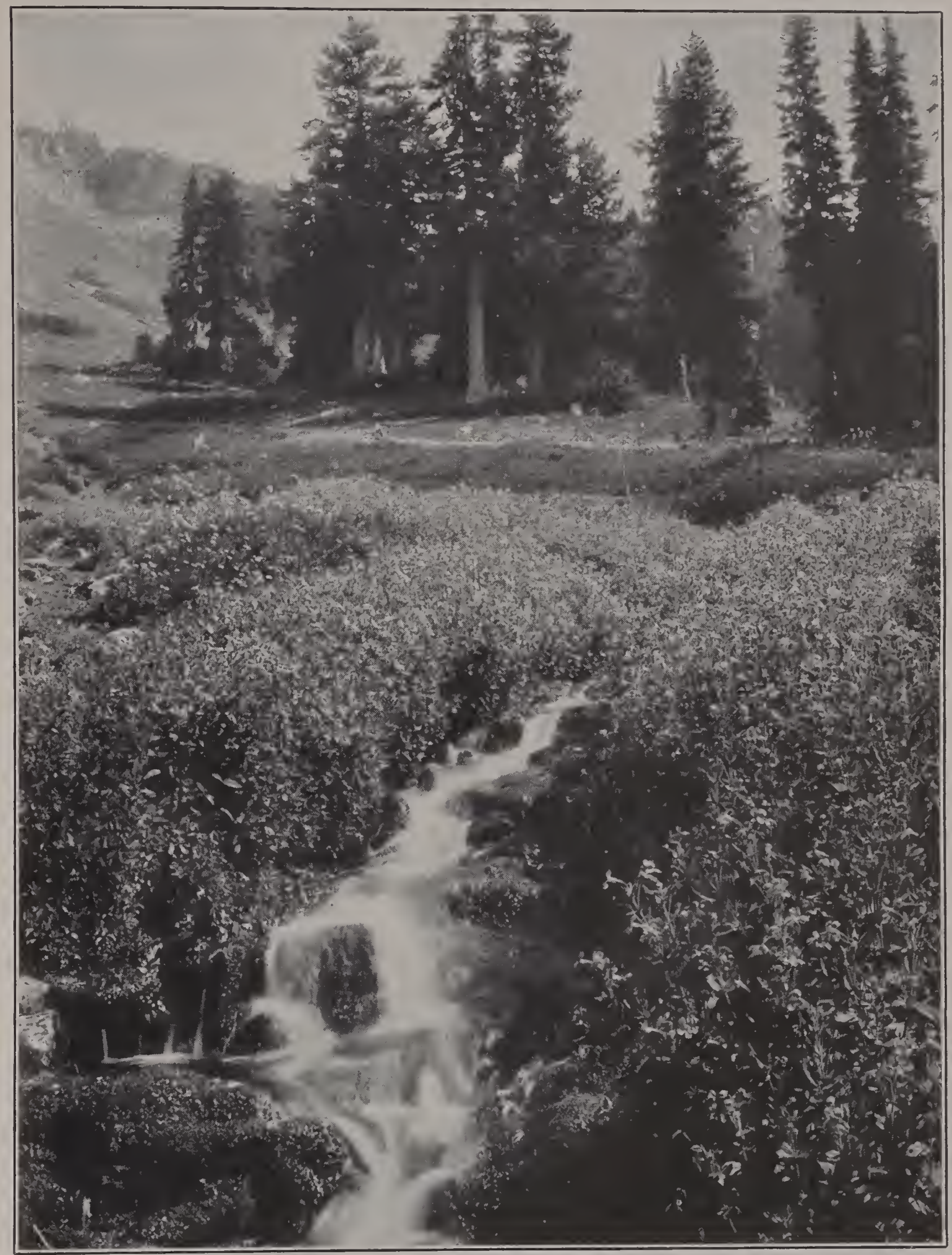

FIg. 26.-Monkey flower (Mimulus alpinus).

Color of flower, yellow; height of plant, 1 to $1 \frac{1}{2}$ inches; blooms July and August.

Photograph by $\mathbf{A}$. H. Barnes.

account of its size and peculiar robust mode of growth among plants so slender and highly colored.

$A$ large number of plants contribute the yellow color to these flower beds. The mountain dandelion, Agoseris alpestris, is a plant closely 


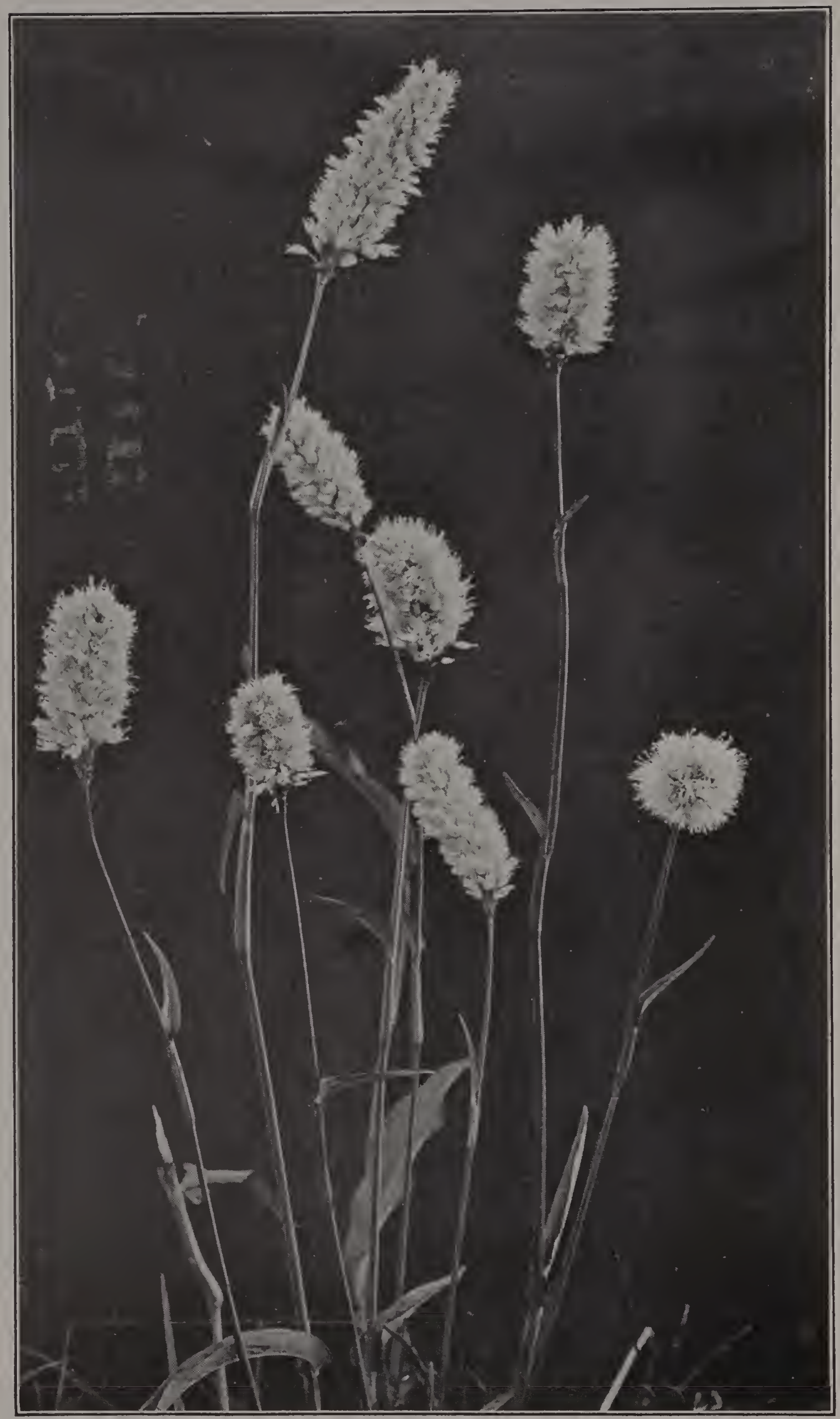

FIG. 27.-Mountain dock (I'olygonum bistortoides).

Color of flower, white; height of plant, 1 to 2 feet; blooms July and August. Photograph by $\Lambda$. II. Barnes. 
resembling the common dandelion. The potentilla, Potentilla flabetlifolia, is a common buttercup-like plant already referred to. 'There are two or three species of arnicas, which may be known by their opposite cordate or ovate leaves and rather large heads of yellow flowers. One species, Arnica parryi, has its heads entirely rayless and usually solitary. It therefore takes little part in the color scheme. Senecio triangularis may be known by its rather tall stem, small heads, and triangular dentate leaves. It requires plenty of moisture and is found near streams and springs. It ranges from Longmire Springs to the "Camp of the Clouds."

The pentstemons, epilobiums, asters, erigerons, claytonias, etc., contribute pink and purple in ever varying shades, making the harmony complete.

The tree groups among these flower beds are composed largely of the alpine fir, alpine hemlock, Alaska cedar, and the white-barked pine, Pinus albicaulis. This pine is rare on the south side; but is common on the north and east sides of the mountain. The same is true of an alpine form of the tideland spruce. These trees are peculiar in that their trunks rise up like spires while their short branches are bent downward by the weight of the snow. In the fierce struggle for existence their wood has been strengthened to a remarkable degree as compared with wood of trees at sea level. Many of the shorter trees remain buried for months in snowdrifts 15 to 20 feet in depth. It is not strange that such trees should have a gnarled and distorted appearance even at an altitude of 5,500 feet. Between this altitude and 6,500 feet there is a marked change to smaller plants, steeper slopes and poorer soil, but no diminution in color. In fact, the color scheme is intensified, and many of the most beautiful flower beds are found about 6,000 feet or a little abore.

Phlox diffusa (fig. 28) is here arrayed in large masses of larender flowers changing to white as they become older. 'The painted cups here vary from red to crimson and sometimes even to purple. There are three or four different species of them in these flower beds. Castillcia miniata is known by its entire lanceolate leaves. The other species are similar to each other and are known only to botanists. Cusick's speedwell which, in the second zone was said to be partially hidden under the larger plants, is seen to better advantage here and often forms beautifui blue patches to the exclusion of other plants.

The blue gentian, Gentiana calycosa (fig. 29), with its large funnelform flowers and opposite sessile ovate leaves, grows here in moist places. It is one of the most admired of the blue flowers found on the mountain. It is not strange that it attracted the trained eye of Dr. Tolmie, the first botanist to visit the mountain. It was named from specimens collected by him near the Puyallup Glacier in 1837 . It is 
abundant at the end of the trail leading into Van Trump Park and along the lower meadows on the glacier trail leading into Paradise Valley. It may be found from the lower meadows to timber line.

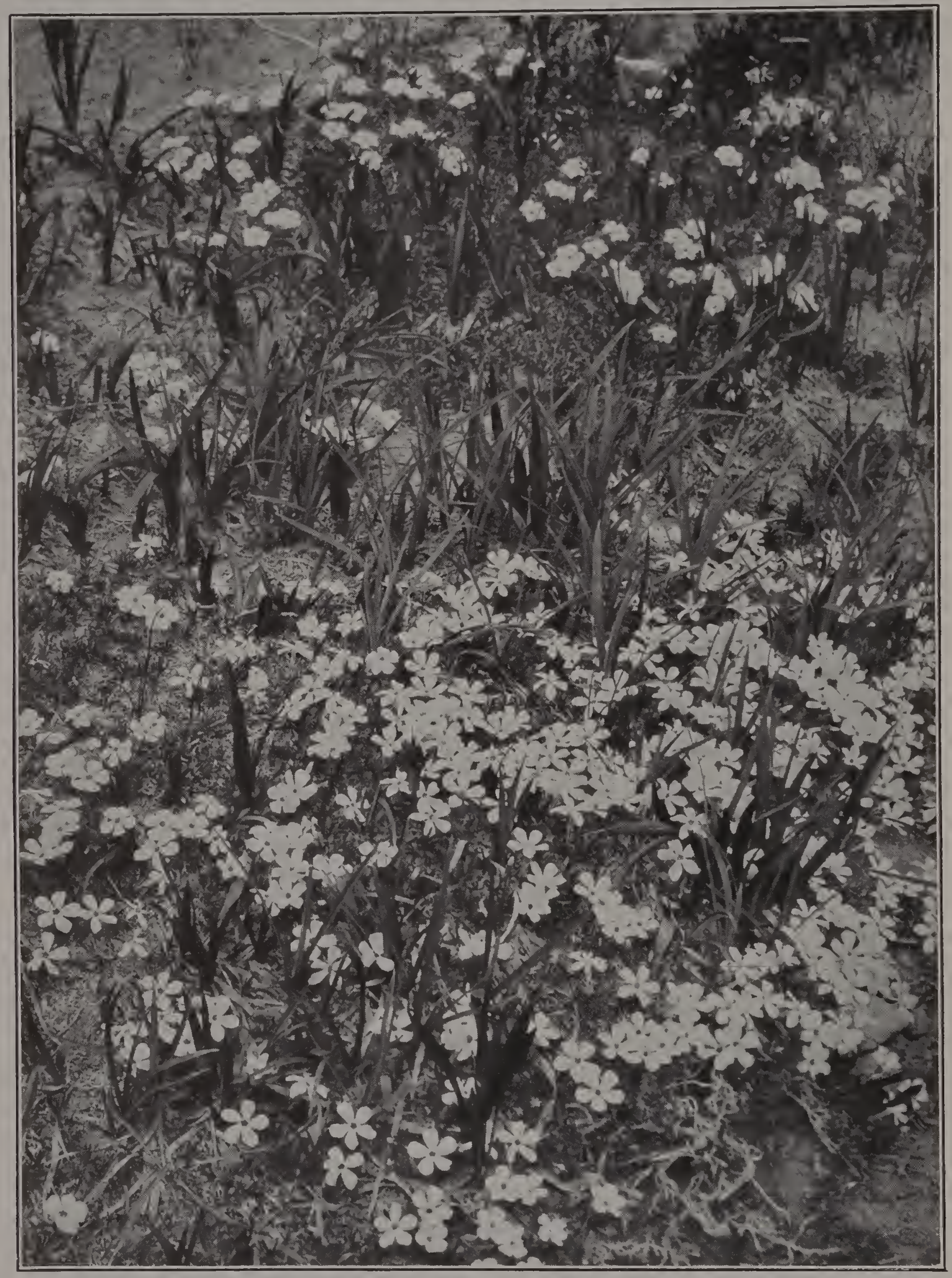

Fig. 28.--Mountain phlox (Phlox diffusa).

Color of flower, lavender to white: height of plant, 1 to 4 inches; blooms July and August.

I'hotograph by A. H. Barnes.

It blooms rather late, and may be found in October with its large, beautiful blue flowers up through a foot of snow, being held upright by small branches of the rosy spiraea or other shrubs common to 
wet places. Sereral species of the aster family are also seen in this sorry plight. Many of the weaker plants, such as the specdwell, are buried several times under the snow before it becomes continuous for the winter. After the temporary snows melt off, thesc plants soon straighten up and continue on as though they nercr had been buried.

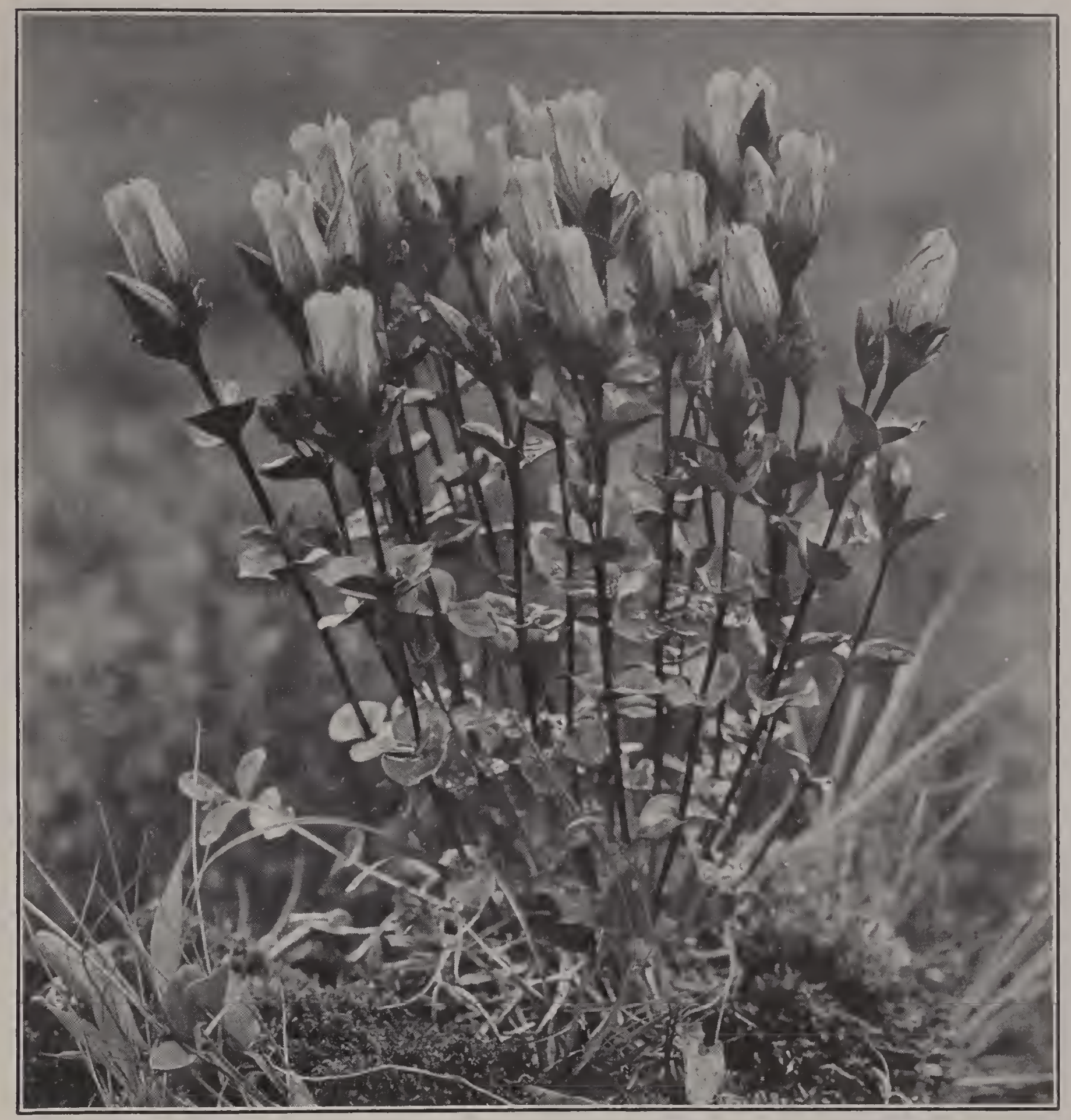

FIG. 29.--Blue gentian (Gentiana calycosa).

Color of flower, blue: height of plant, 10 to 18 inches; blooms August and September.

Photograph by A. H. Barnes.

The framework of these plants which grow late is so well prescrved in the following spring after the winter snows thaw that the old plant is sometimes mistaken for the new. Here we find the principle of cold storage applied in a natural way. In this arca there is a gradual transition to plants of a higher altitude. Many of the conspicuous plants from the area below are also found here though in a more depauperated condition, hence there is a general blending 
together of the high and low altitude trees. This transition area is, perhaps, the most interesting, because of the great variety of plants and the infinite combinations found under different conditions of soil, moisture, and light.

The white and yellow deer-tongues, the arctic lupines, the valerians, and the polemoniums are abundant in the lower part of this region though not in the upper near 6,500 feet. Lupinus volcanicus is a characteristic timber-line plant all around the mountain. It differs

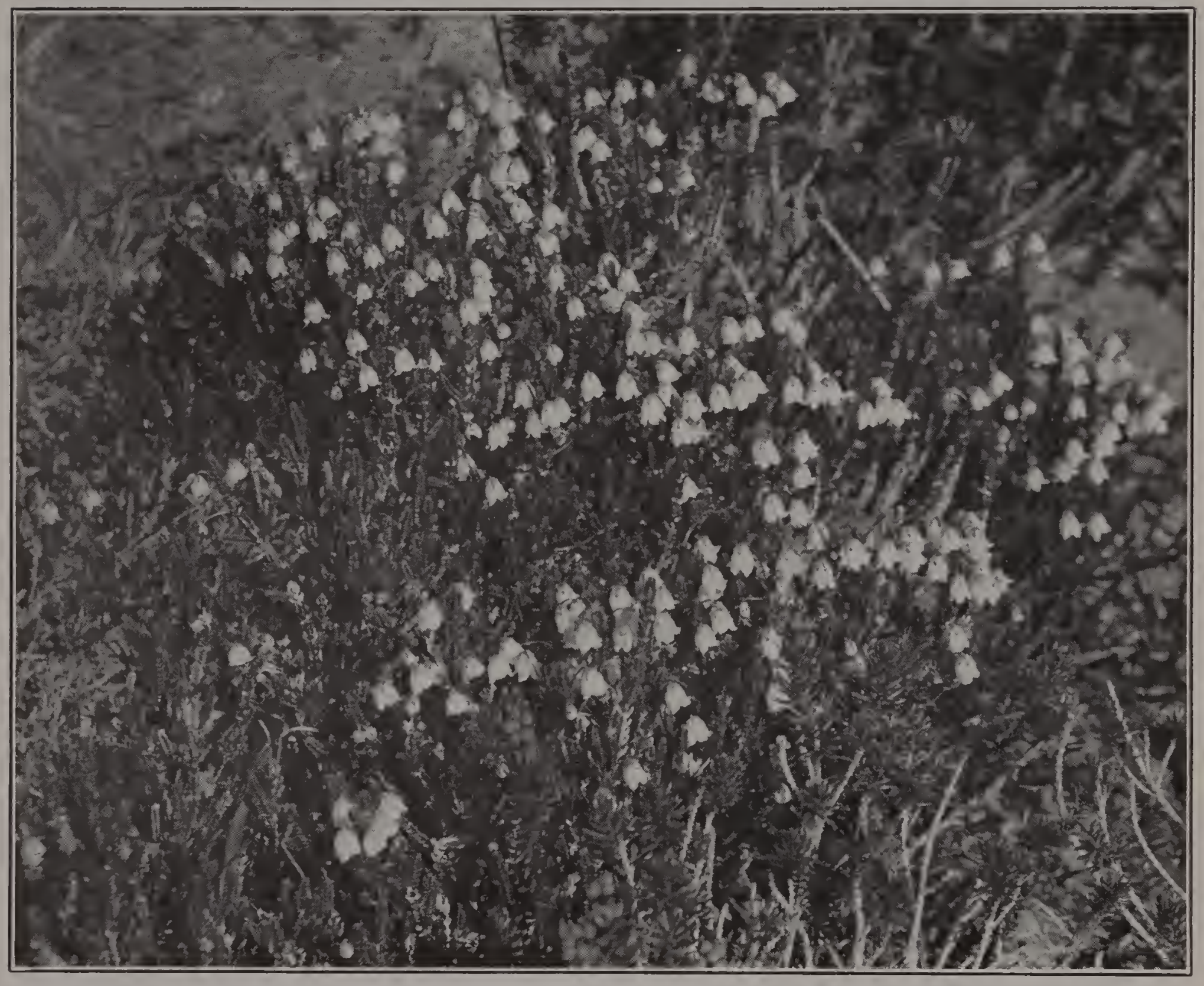

Fis. 30.- White heather (Cassiope mertensiana).

Color of flower, white; height of plant, 6 to 10 inches; blooms July and August.

Photograph by A. H. Barnes.

from the plant in the lower meadows by its greater pubescence, coarser and shorter stems.

The white heather, Cassiope mertensiana (fig. 30), is one of the most attractice plants in the heather group. It is known by its bell-shaped, drooping flowers and rather short stems with small imbricated leares. The red heather, Phyllodoce empetriformis (figs. 31 and 32), which is much more robust, often grows with it. It extends from 3,200 feet timber line. The yellow heather, Phyllodoce. 
glanduliflora (fig. 33), is common, though less conspicuous than its relative with its greenish yellow flowers. Its range is limited to the vicinity of timber line.

Common in the same locality are two short, dainty pentstemons, Pentstemon procerus and Pentstemon confertus. The former has beautiful blue flowers, while the latter has a delicate creamy yellow color. At this altitude they are about 3 inches in height, while in the lower zone they are much larger. Several dainty species of the

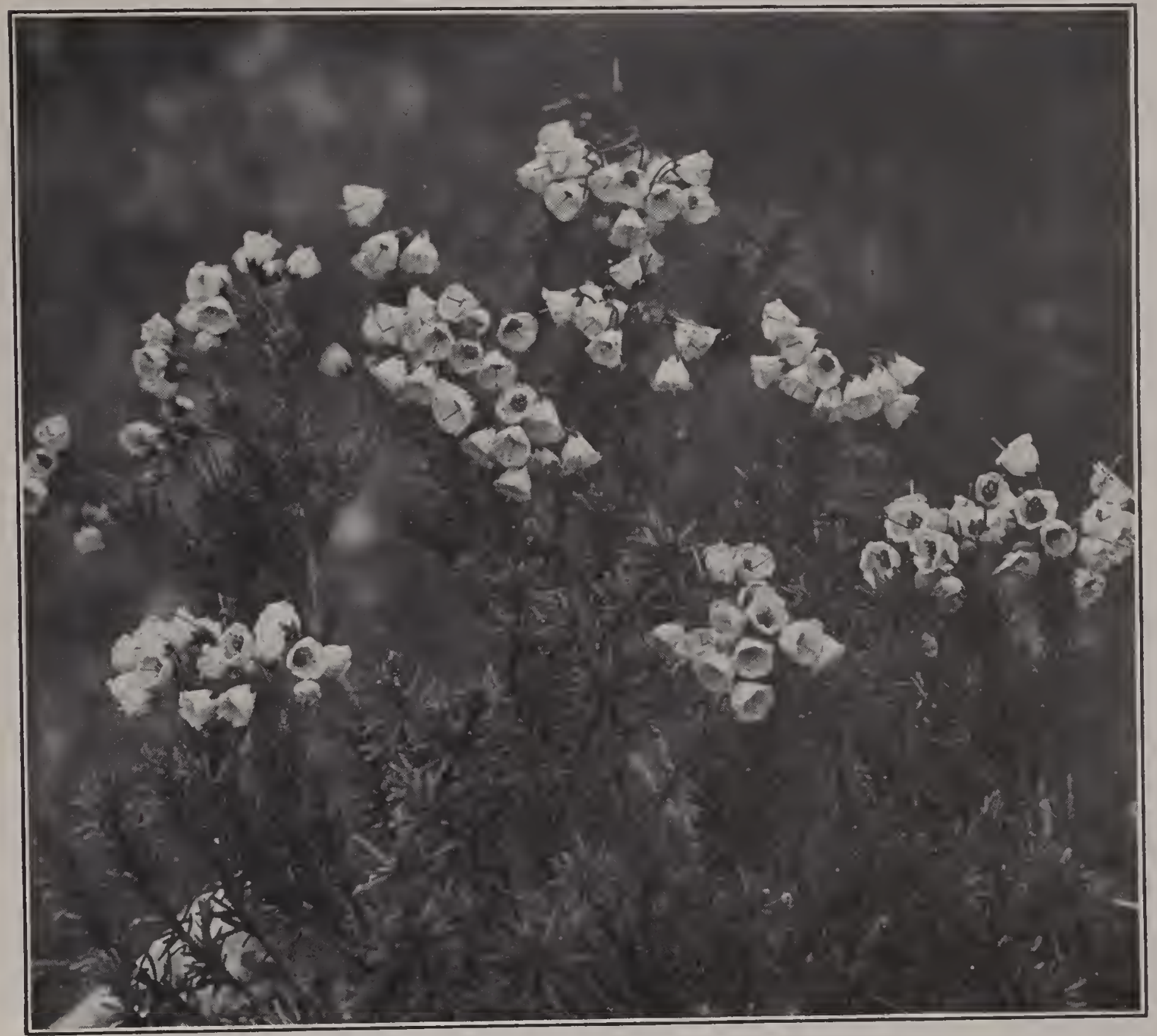

Fig. 31.--Red heather (Phyllodoce empetriformis).

('olor of flower, red; height of plant, 10 to 18 inches; blooms July and August. Photograph by $\Lambda$. H. Barnes.

genus Pedicularis are scattered here and there among the heather. Gitia nuttallii is often called phlox on account of its large white phloxlike flowers, and palmately 3 to 7 parted leaves. This is rare in Paradise Valley though common on the west side of the mountain. It blooms during the early part of July. It is quite ornamental like its relative the phlox, which often is associated with it. The rills are adorned with the alpine minulus as below. The epilobiums are abundant, corering the ground with their small pink flowers. 
Two cud weeds, Antennaria media and Antennaria lanata, are easily known by their white wooly appearance and rather short stems. The latter is larger with denser heads and narrower leares than the

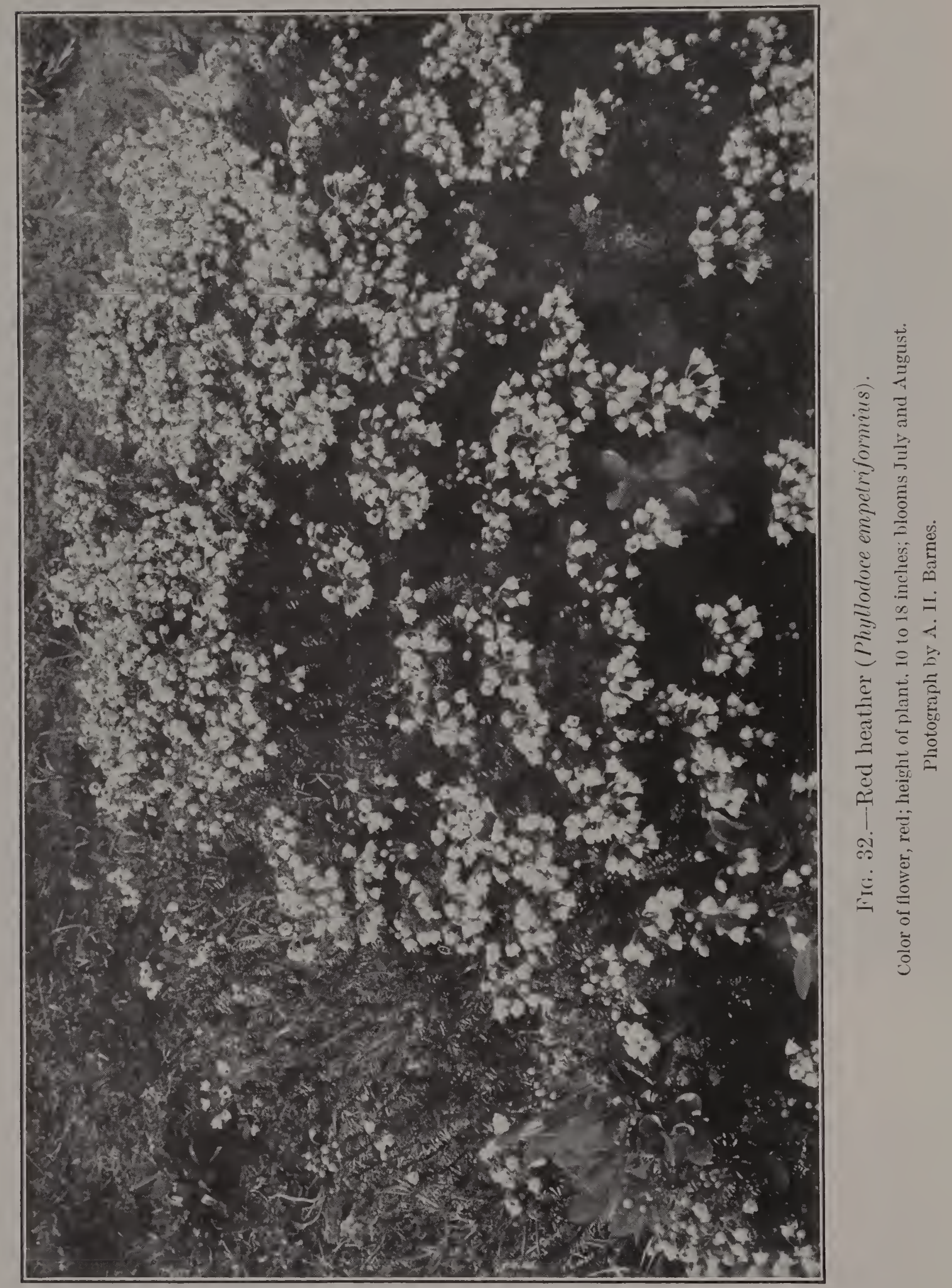

former. These plants are related to the Swiss edelweiss. They do not have the star like heads of the Swiss plant. The dog violet, Viola retroscabra, and the early violet, Viola sempervirens, are found 
in this zone all around the mountain. They are never seen in great abundance anywhere. The dog violet has bluish-violet flowers and orate leaves while the other is yellow with round cordate leares. The former is more abundant than the latter. The pink family has several representatives such as Sulssdorf's silene (fig. 34), two or three arenarias, or sandworts. These plants, like the violets, gire variety by their somewhat equal distribution over the grassy slopes.

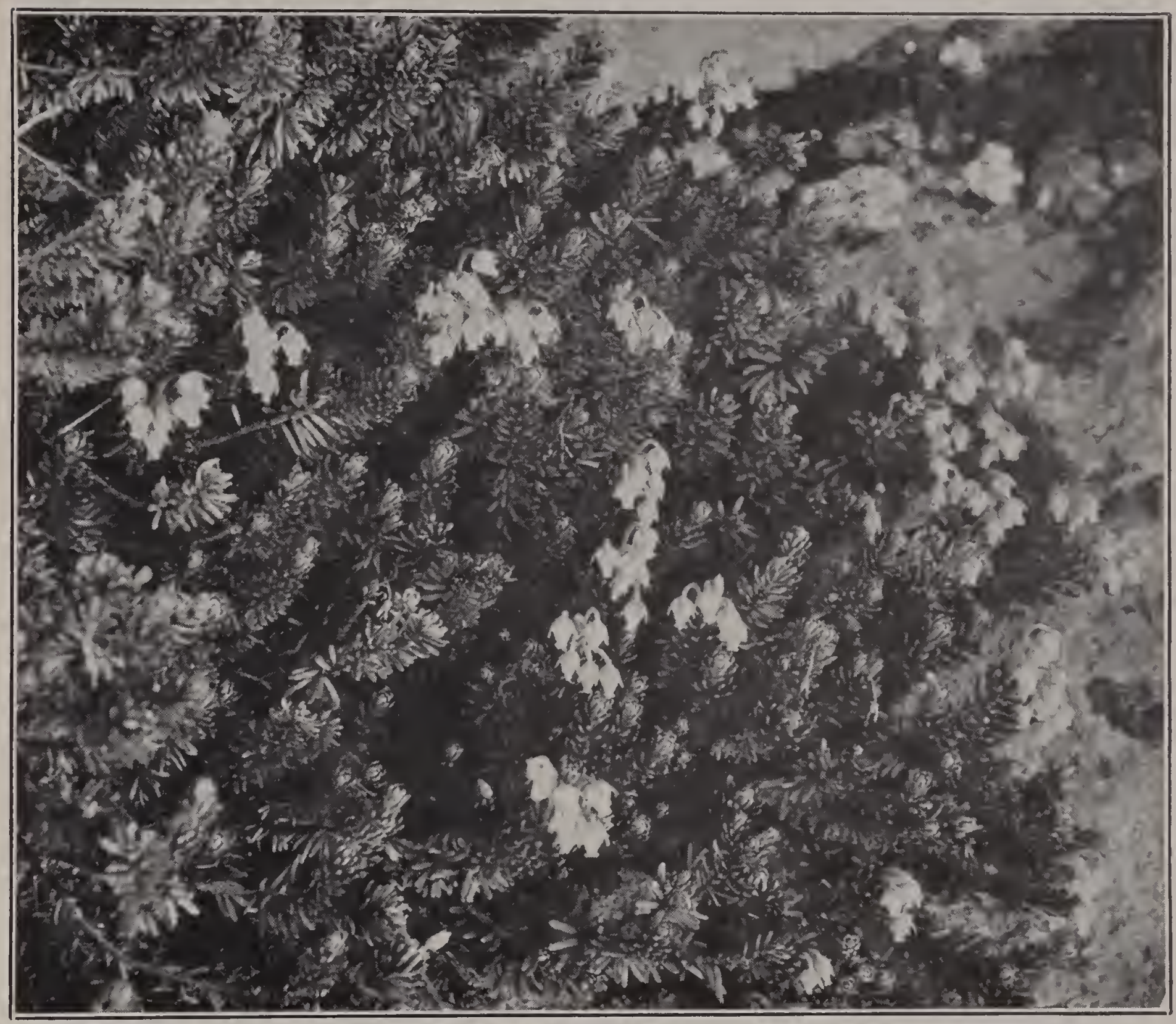

FIg. 33.-Yellow heather (Phyllodoce glanduliftora).

Color of flower, yellowish white; height of plant, 6 to 10 inches; blooms July and August. Photograph by A. H. Barnes.

The saxifrage fanily in this zone takes to the rocks to avoid competition. Many of these grow in large mats, and cover the bare rocks and soil with a beautiful carpet of small white flowers. Saxifraga tolmiei (fig. 35) is the most noted and the most common on the rocky arcas below timber line. Many tourists stop and pay homage to this little plant, not only on account of its beauty but also because of its apparently inhospitable environment. Saxifraga caespitosa grows more on moist crags and in still denser and more globular masses than the former. It is also a larger and coarser plant. Saxifraga bronchialis (fig. 36) has a larger flower stalk and grows in drier places, 


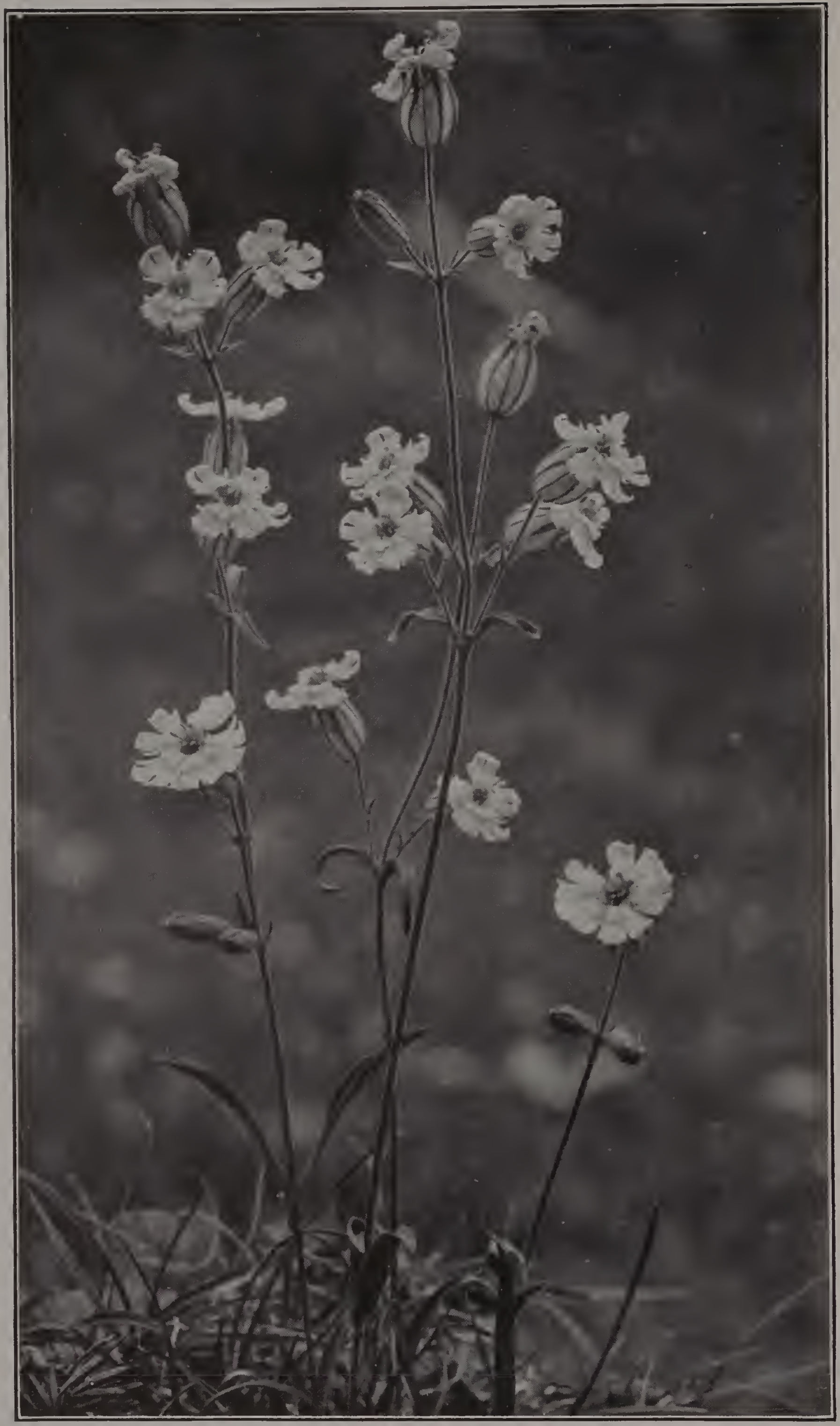

Fig. 34.-Suksdorf's silene (Silene suksdorfii).

Color of flower, pinkish white; height of plant, 3 to 6 inches; blooms July and A ugust. Photograph by A. H. Barnes. 
often embedded on moss-covered rocks. Along the streams there are several other species, which grow here and there with reniform leaves and small white flowers.

The spring beauty, Claytonia lanceolata, is common on the dry grassy slopes, and may be known by its low stemless habit, pink flowers, and lanceolate leaves from a tuberous root which was used by the Indians for food. The Indian basket grass occurs in several of the meadows up in this area. In the upper part of Paradise Valley, on the ridge west of Sluiskin Falls, there is a large field of it near tim-

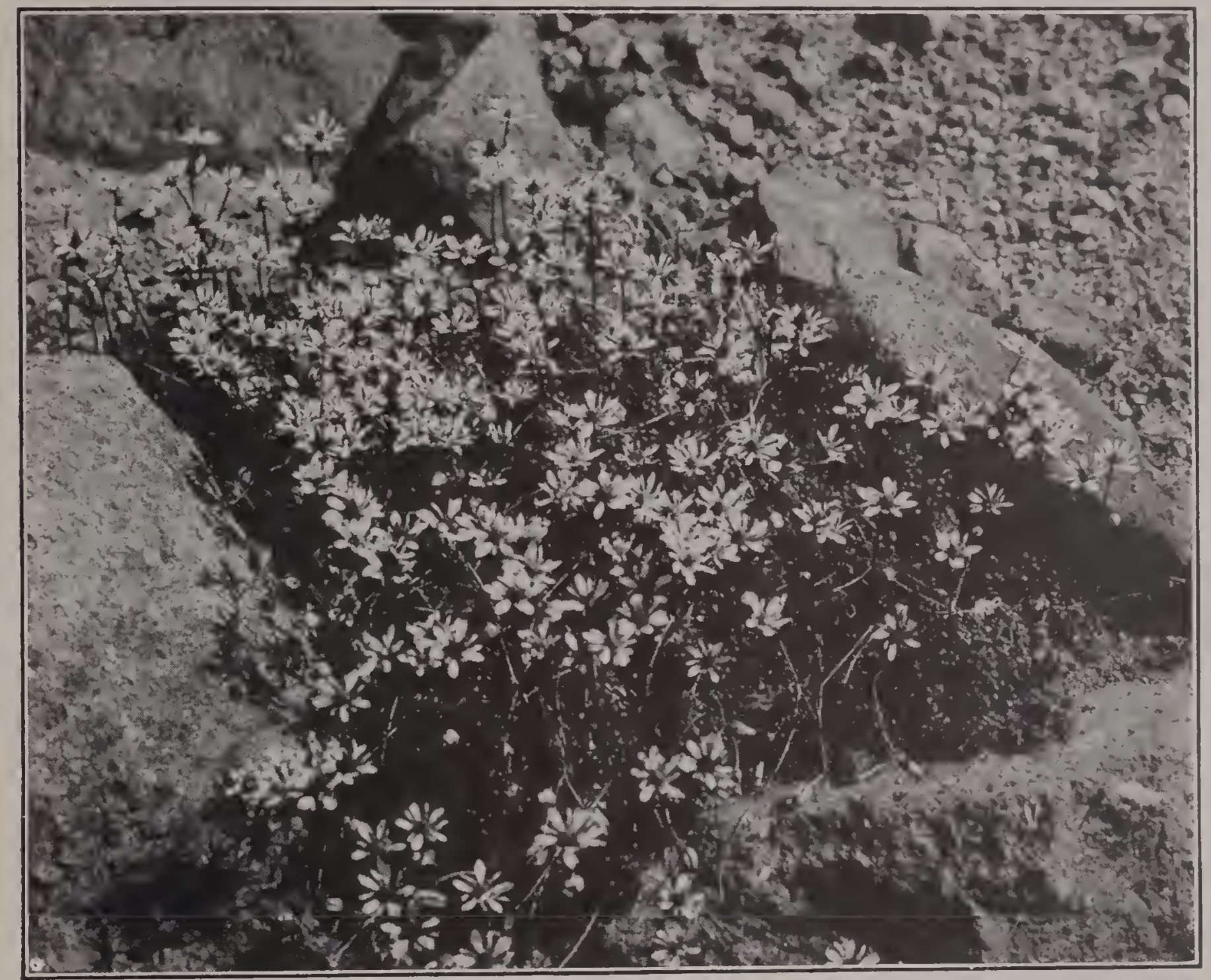

FIG. 35.-Tolmie's saxifraga (Saxifraga tolmiei).

Color of flower, white; height of plant, 3 to 4 inches; blooms July and August.

Photograph by Isahel Curtis.

ber line. These plants are found in full bloom long after those below have gone to seed. 'This plant furnishes an excellent example of what altitude does for a plant. It extends from 2,750 feet, at Longmire Springs, to timber line, about 7,000 feet.

The Alaska spiraea, Lutkea pectinata, forms clusters often excluding other plants. Its creeping habit enables it to form heather-like mats. It has short shrubby stems 4 to 6 inches high, bearing a dense raceme of small white flowers; leaves twice or thrice palmately three cleft. These mats of sharply cleft bright green leaves are very noticeable even where the plant is not in bloom. In and among these mats 
of Alaska spiraea and heather grows a small form of the pale laurel not more than 2 to 4 inches high. It may be known by its saucershaped pink flowers, with pouches for the stamens, and by its ovate to lanceolate leaves, dark green above and whitish beneath.

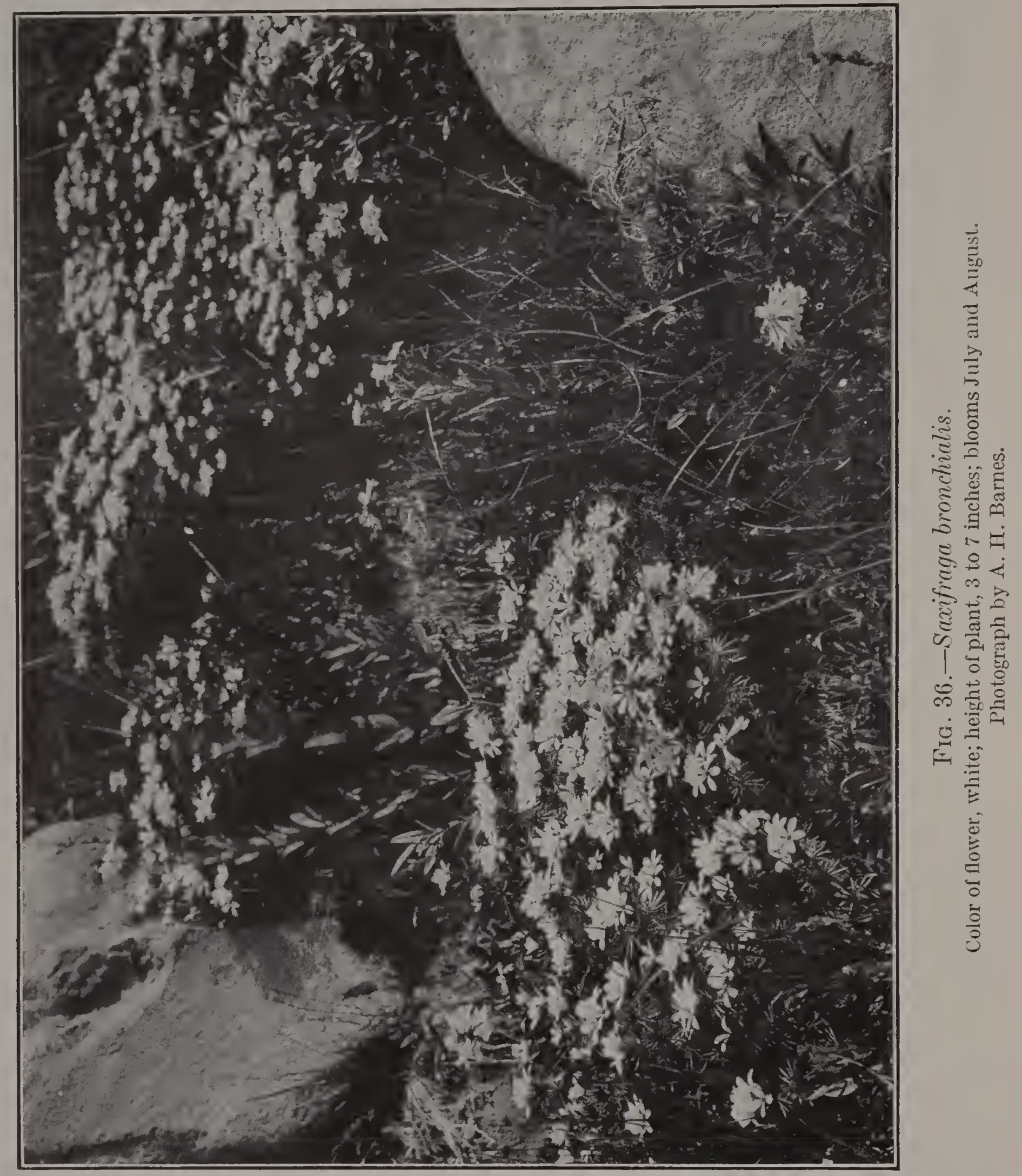

THE FOURTH ZONE.

The trees which reach timber line are the alpine fir, the alpine hemlock, the Alaska cedar, and the white-barked pine. There are a few gnarled specimens of the latter on the ridges west of Sluiskin Falls, but the alpine fir, alpine hemlock, and Alaska cedar are the common trees. The trailing juniper, Juniperus communis sibirica, is common at timber line and extends down far below, trailing over rocky ledges. Its trailing habit, sharp foliage, and green berries 
readily distinguish it. One of the most characteristic plants at timber line is the golden aster, Erigeron aureus. This dainty little plant, about 3 or 4 inches high, has bright golden-colored ray flower's and a solitary head. The three heathers are common at timber line, at which elevation another rather rare heather is added, Harrimanella stelleriana. This plant spreads out flat on the ground with the leaves extending out from the two sides of the stem, with a terminal single flower. Some of the heathers are called Scotch heather, but there is very little similarity between our plants and the European.

A small goldenrod, Sotidago scopularum, 6 inches to a foot high, grows among the rocks and gnarled trees. This dwarfed plant, with its small yellow flowers, looks puny when compared with the large plants of the fields in lower altitudes. Several asters, erigerons, pentstemons, and painted cups from the lower slopes reach timber line, while two or three of these extend beyond into the pumice fields. This is also true of the two little woolly cudweeds before mentioned.

\section{THE FIFTH ZONE.}

In the pumice fields and rocky ledges above timber line one of the most beautiful plants is Lyall's lupine, Lupinus lyallii (figs. 37 and 38). It extends upward to about 8,000 or 9,000 feet. It is small and forms a rosette with its silvery palmate leaves and numerous stems, each bearing a short raceme of brilliant blue-purple flowers. It blooms soon after the snow disappears, and keeps on blooming until about the middle of August. The season for all plants in these alpine and subalpine regions is governed by the depth of the snow. The position and depth of snowdrifts depend largely on the winter conditions, which vary from year to year. The flower beds on these pumice fields have many extreme changes. One locality may have little snow, while near by may be a drift 20 feet deep. In the former the plants spring forth early, while in the latter they are buried in snow, which may not thaw for weeks. In the former locality the plants may ripen their seeds, while in the latter the autumn snow may bury them in full bloom. For this reason the date of blooming can not be given as we speak of it in regard to our common plants, which vary comparatively little.

Pentstemon rupicola is one of the most highly-colored plants on the mountain. It is often seen on cliffs. It has short, prostrate, shrubby stems with thick leaves and rose-crimson flowers. Very similar to the above is Pentstemon menziesii with duller purple flowers. These extend to an altitude of nearly 8,000 feet. Spraguea multiceps grows in the volcanic ash from a thick rootstalk bearing several short, stems with entire spatulate leaves and pinkish-brown heads. Growing with the above is a member of the dock family, Eriogonum pyrolaefolium coryphaeum (fig. 39). 'This has one to four 
flowers of a purplish yellow color in an umbel with short flower stalks and thick oblong leaves. Polygonum newberryi belongs to the same family as the above. It may be known by its somewhat prostrate habit, rather fleshy ovate leaves, and small greenish flowers.

On the storm-swept peaks and ridges in the crevices of the rock may be found the tiny lace fern, Cheilanthes gracillima, with its numerous thread-like roots securely anchored from the fury of the storms. It is seldom more than 3 or 4 inches high. Nature has made ample provision for its inclement environment by clothing it with a furry woolly garment. It is found on the summit of Pinnacle Peak and on Plummer Peak. Sometimes it is found as low as

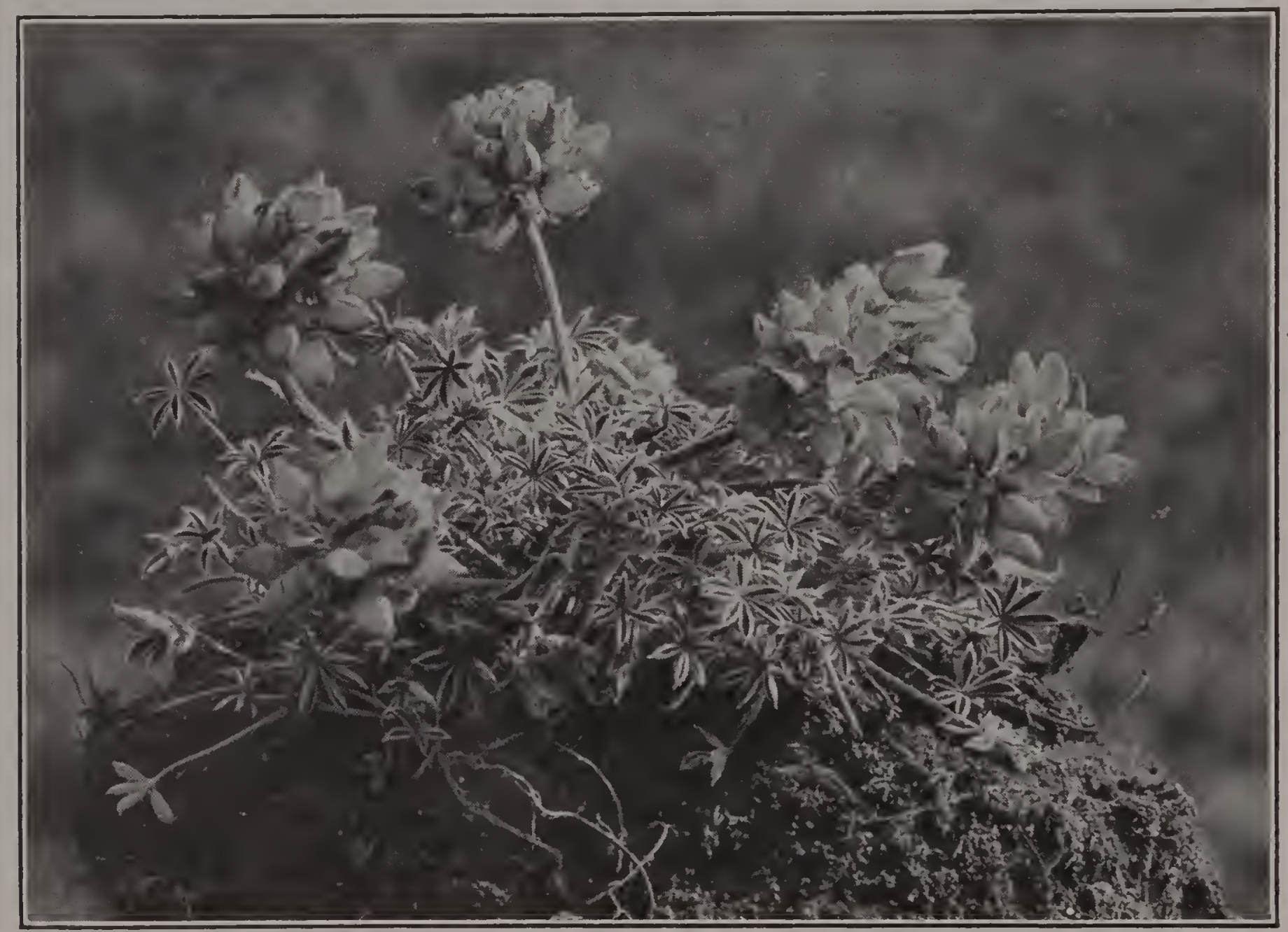

Frg. 37.-Lyall's lupine (Lupinus lyallii).

Color of flower, bluish purple; height of plant, 2 to 7 inches; blooms July and August. Photograph by $\AA$. H. Barnes.

the peaks overlooking the terminal moraines of the glaciers and the rocky pinnacles above the road leading from Narada Falls to the Nisqually. Its companion plants are the mountain polypody, Polypodium hesperium, the kinnikinnik, Arctostaphylos uva-ursi and Pentstemon oreopola. Sometimes Phlox diffusa is woven in and out among them. A study of any one of these peaks is extremely interesting, whether the student be a botanist or not.

Competing with Lyall's lupine for first rank as to beauty of foliage and brilliancy of flower is Phacelia sericea, an elegant plant of the water-leaf family. It may be known by its silvery foliage and purplish flowers, stem leafy to the top and leaves pinnately parted 
into linear divisions. This plant was formerly seen along the trail to the summit. The writer failed to see a single plant last summer along that route. It doubtless makes too good a souvenir to be let alone. Polemonium elegans may be known by its strong odor, alternate pinnately parted viscid leaves, and cymulose cluster of blue flowers with yellow centers. A small aster, Erigeron compositum, having pinkish flower and dissected leaves, grows here. Ilutsa nana, another composite plant, may be known by its large yellow flowers, 2 to 6 inches high, with sticky pinnatifid leaves, mostly radical, from a long branching rootstock. This plant also is now

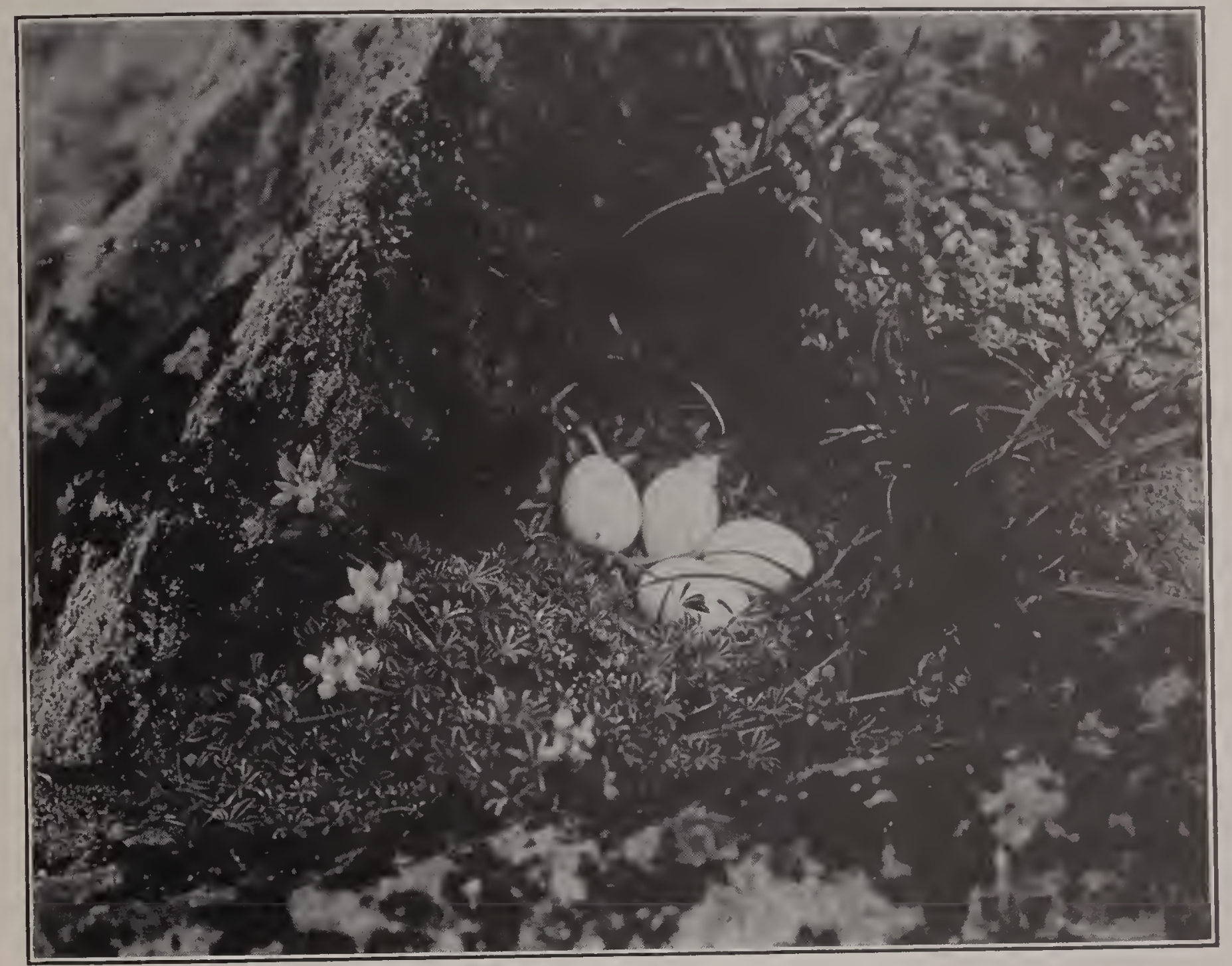

FIG. 38.-Lyall's lupine (Lupinus lyallii).

Color of flower, bluish purple; height of plant, 2 to 7 inches; blooms July and August. Photograph by A. II. Denman.

rare along the trail to the summit. It is not likely that the tourist would carry this plant after its viscid quality was discovered, though its large golden yellow flowers would tempt the flower destroyer to pluck it.

Draba aureola, a yellow mustard, grows rather sparingly on the rocky ledges at Camp Muir and at similar altitudes around the mountain. Its lower leaves are oblanceolate, usually less than half an inch long, and the upper are oblong. It is densely pubescent all over, even the oblong seed pods being covered with fine stellate hairs. Smelowskia ovalis is another hardy plant which belongs to the 
mustard family. It has hoary white foliage, creamy white flowers in terminal racemes and pinnatifid leaves. These two cruciferous plants just mentioner reach a higher altitude than do any other

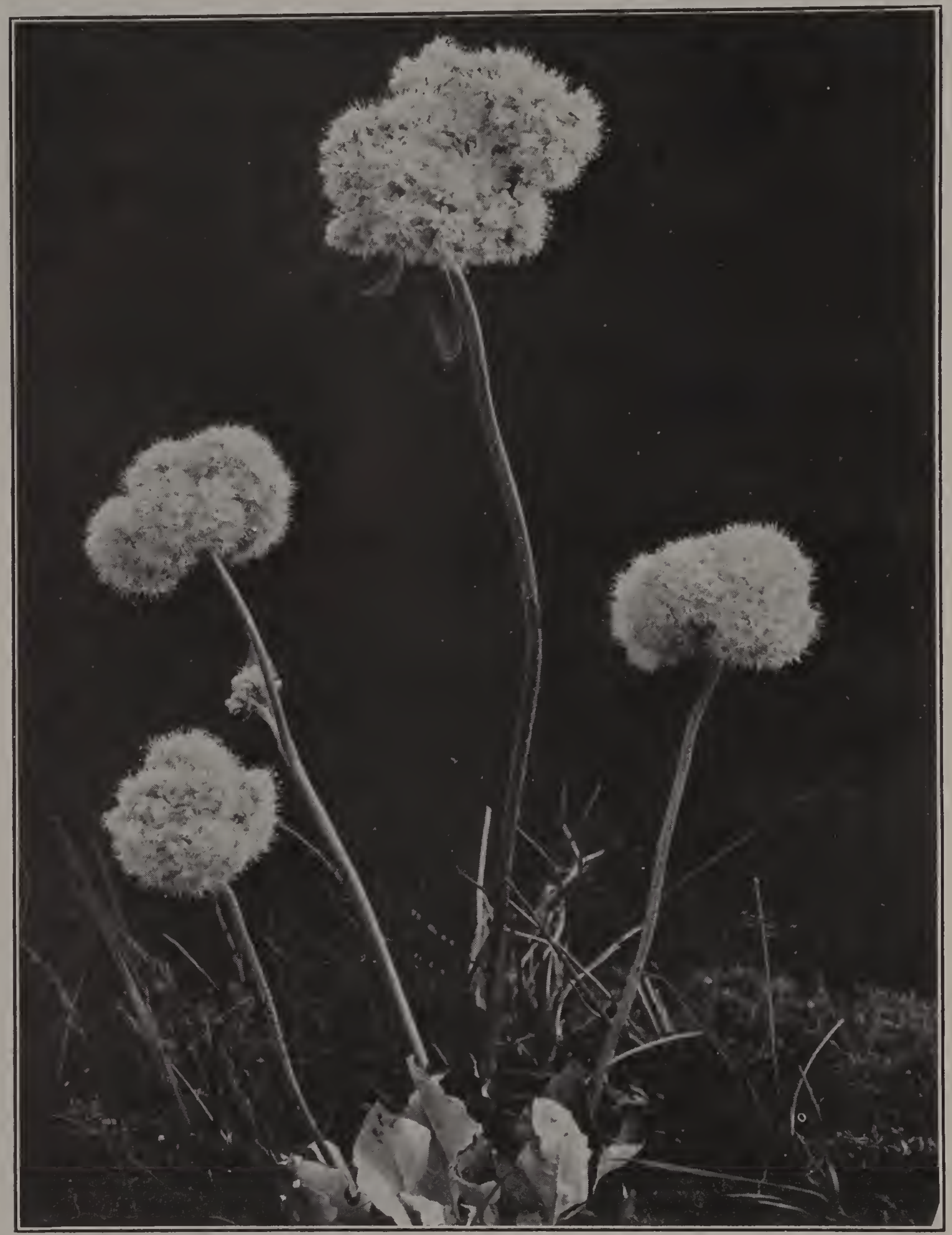

Fig. 39.-Eriogonum pyrolaefolium coryphacum.

Color of flower, yellowish purple; height of plant, 3 to 8 inches; blooms July and 1 ugust.

Photograph by $\Lambda$. H. Bames.

flowering plants on the mountain. Perhaps the smelowskia beats its companion a little. Two grasses, Poa lettermani, Poa suksdorfi, and a sedge are close competitors for the highest honors. 


\section{INDEX TO SPECIES.}

[Roman numerals indicate descriptions or references; italic numerals indicate illustrations.]

Abies a mabilis grandis.

Achlys triphyila.

Adder's tongue.

Agoseris alpestris.

Alaska cedar spiraea.

Alder

Allotropa virgata.

Alpine beauty. fir ........ willow.

...........

nemone deltoidea. occidentalis .

Anemone, western

Antennaria lanata. media.

Arctic lunine.

A rctostaphylos uva-ursi.

Arnica parryi. .

Ash, mountain

Aster, golden

$$
\text { purple. }
$$

A valanche lily

Biliukulla formosa.

Bird's-foot bramble.

Bishop's cap.... .

Bear grass

Black pine..

Blue gentian.

Brate

Bramble, bird's-foot snowy.

Broad-leafed maple

Bunchberry. See Canada dogwood.

Buttercup, Suksdorf's

Calypso borealis.

Canada dogwood.

Capnoides scouleri...

Cascara...

merte........ miniata. miniata...

Cedar, $\Lambda$ laska. white.

Cheilanthes gracillim

Claytonia lanceolata.

Clintonia uniflora.

Coral root

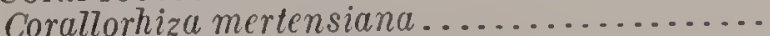
multiflora. striata.

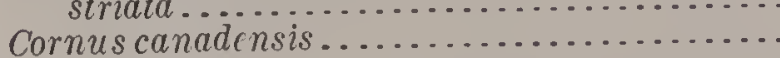

Cotton grass....

Cottonrood.

Cud weeds.

Currant mountain ....

Cusick's speedwell... . . . . . . . . . . . . . . . .

Cytherea bulbosa

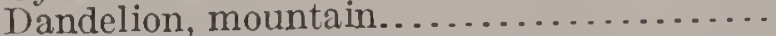

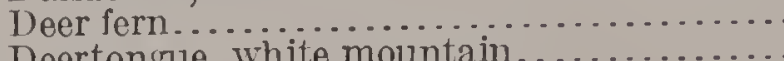

Deertongrie, white mountain........... 23, 24

Deril's club

Dock, mountain..

Dodecatheon jeffrevi.................. 21,20

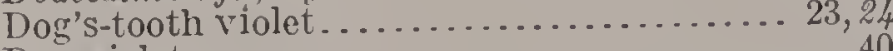

Dog violet.

Dogwood, Canada.

Dollglas fir.

Douglas spiraea.
2,13

2, 13

23, 24

33

$2,35,44$

44
2

4,5

44,45

$3,35,44$

8, 8,9

9,10
$4,27,28$

40
40

25,31

46
35

35
15

45

21,22

4,5

19

17,17

12
35,37

12
19

19

23,25

11

11

2

38,38

35

26

2
46

43

7,7

18

11

6,7

21

40

32

35

33

4

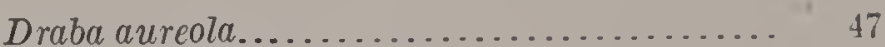

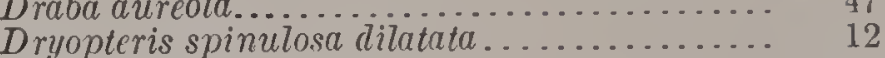

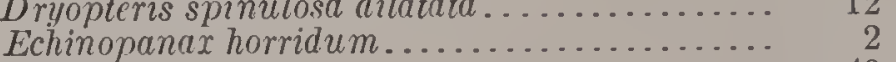

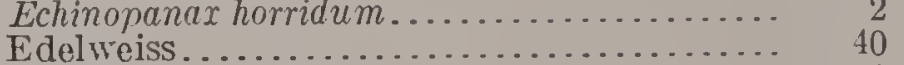

Elephant's trunk.......................... 21

Elk grass.................................. 17,

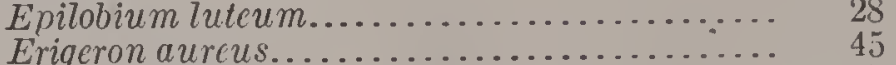

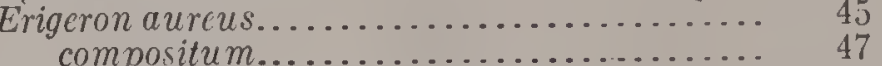

Eriogon um p!rolaefolium coryphacum.................... 45, 48

Eriophorum polystachyon................. 21

Erythronium........................ 22

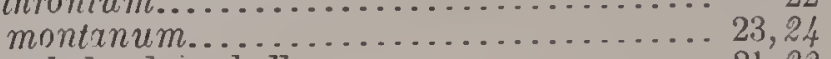

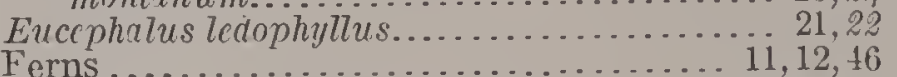

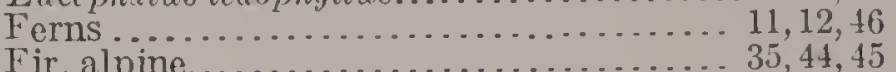

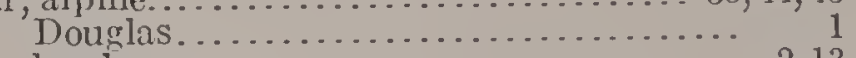

lovely ............................... 2, 13

noble........................... 2,13

silver........................... ${ }_{2}^{2}$

Fireweed, yellow........................ 28

Forest a nemone..................... $8,8,9$

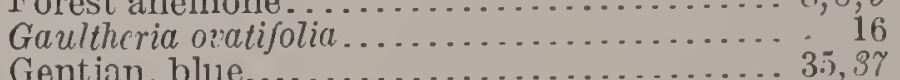

Gentian, blie........................ 35. . . 35,

Gilia nuttallii........................... 39

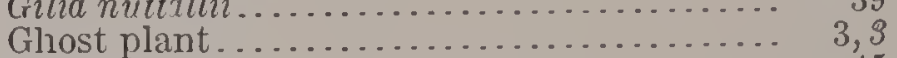

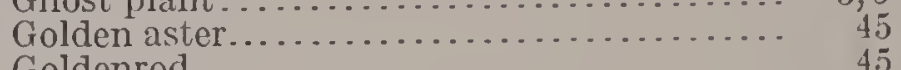

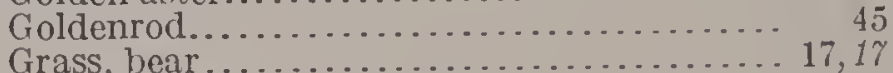

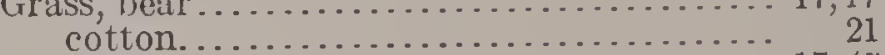

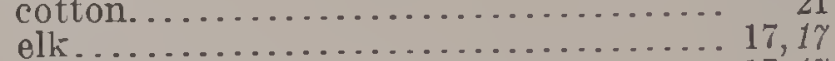

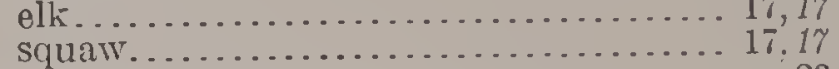

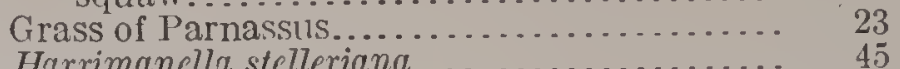

Harrimanclla stclleriana .................. $39,49,40$

Heather, red........................... 35, 39,40

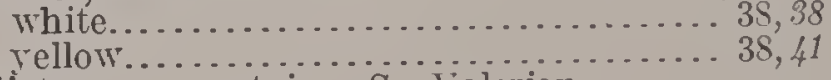

Heliotrope, mountain. Sce Talerian.

Hemitomes congestum.................. 4.5

Hemlock, alpine...................... ${ }_{13}$

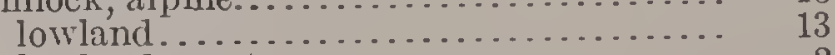

lowland, western......................... ${ }_{47}$

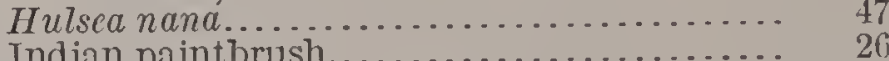

Indian pipe................................... 3,3

Indian pipe............................ 4 . 44

Kinnikinnik....................... 46

Lace fern ........................... 46

Leptarrhena........................... 28,33

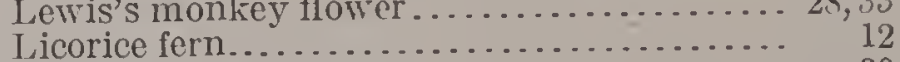

Ligusticum purpureum .....................

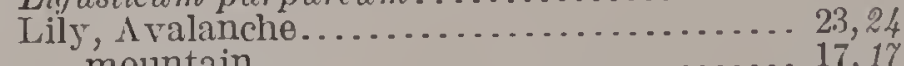

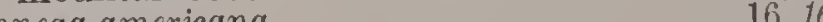

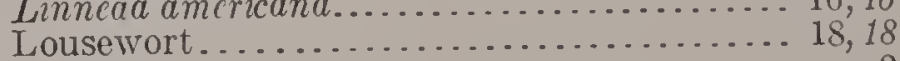

Lovely fir ............................ 2

Lowland hemlock......................

Luina hypolcuca....................... 20

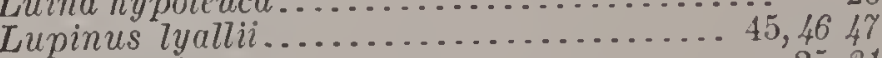

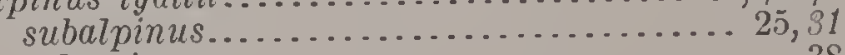
volcanicus....................... $\quad 38$

Lutkea pectinata...................... $46,46,43$

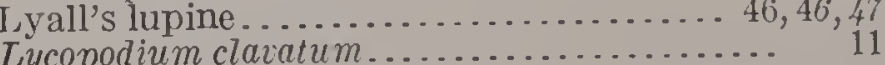

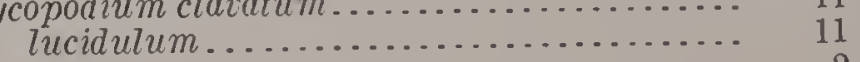

Maple................................ ${ }^{2}$

Merten's colal root .......................

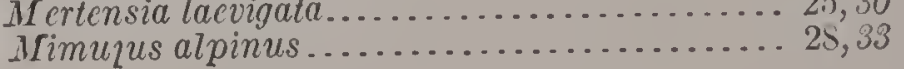


INDEX TO SPE

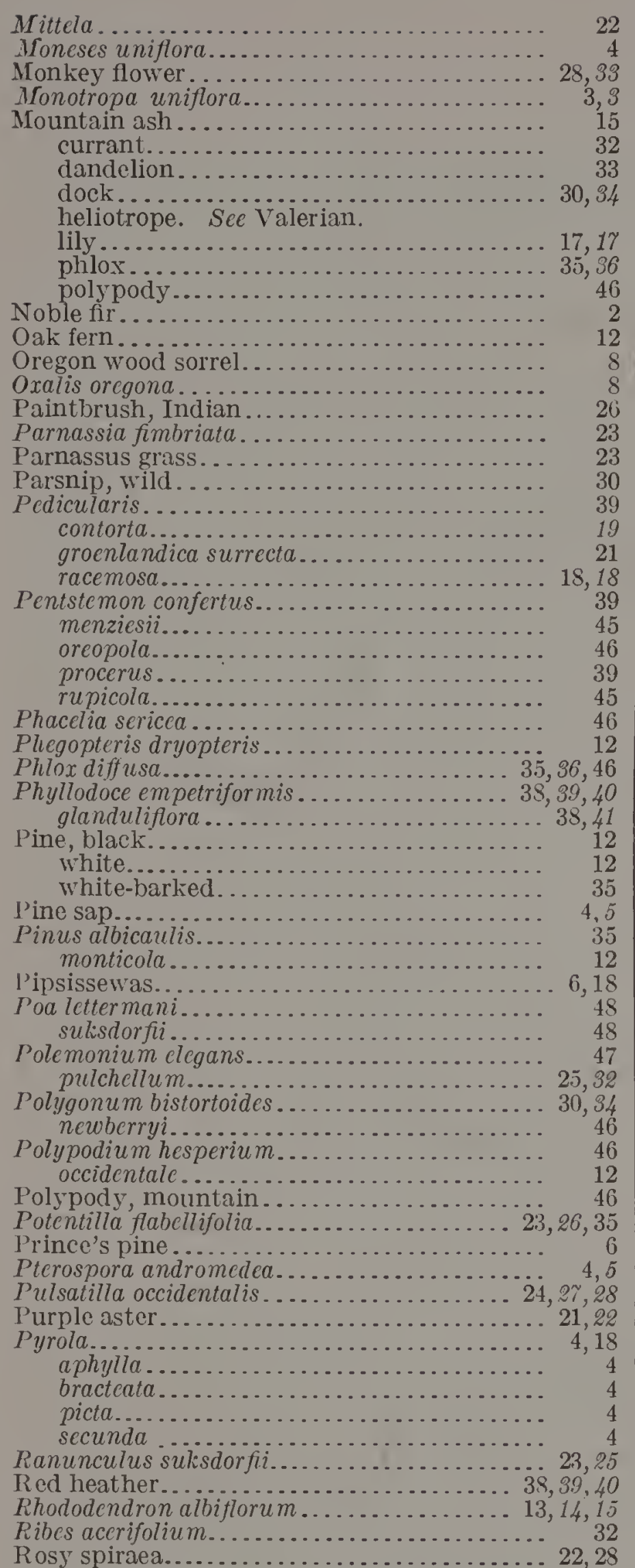

Rubus $0005347223 \quad 0$

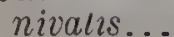

Saxifraga.

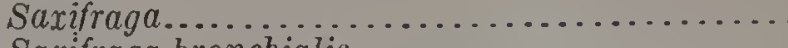

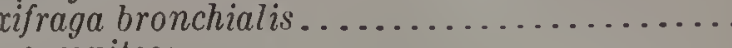
caespitosa. tolmici..

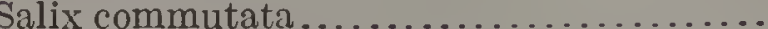

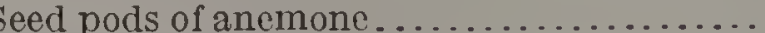

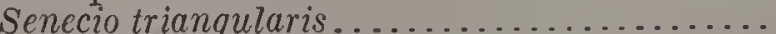

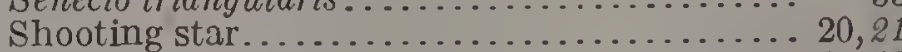

Silene suksdorfii ................... 41, 42

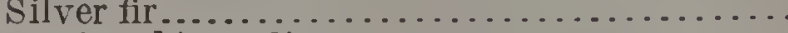

Smelowstia ovalis.

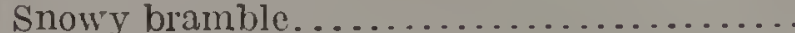

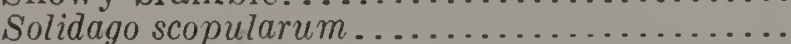

Sorbus occidentatis

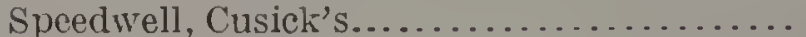

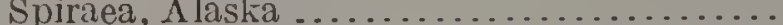

Spiraea densiflora

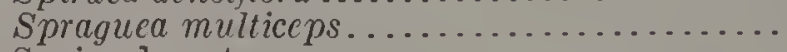

Spring beauty

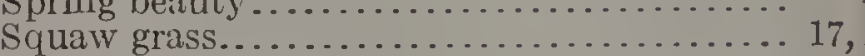

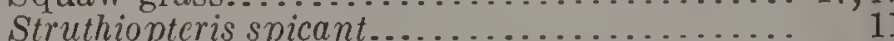

Suksdorf's buttercup................ 23,25

silene......................... 41, 4

Sweet-after-death.......................... 19

Sweet clover........................ 19

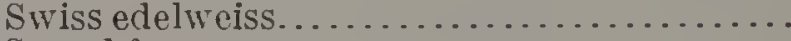

Sword fern

Thuja plicata

Tiarella trifoliata. unifoliata.

Tolmie's saxifrage.

Trailing juniper...

Trautvetteria grandis

Twin flower.

Usnea...

Valerian.

Valeriana sitchensis.

Vanilla leaf.

Veratrum viride.

Vine maple.

Viola retroscabra sempervirens.

Violet, dog. dog's tootli...

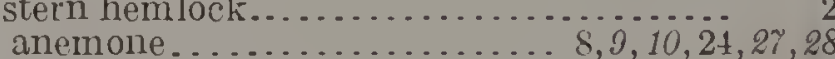

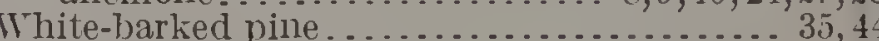

White cedar

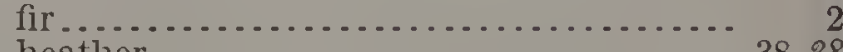

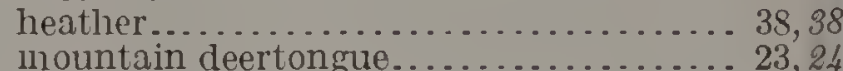

pine............................... 23, 12

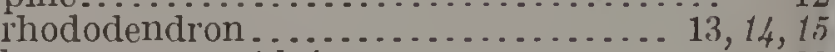

Willow, common A lpine............... 22

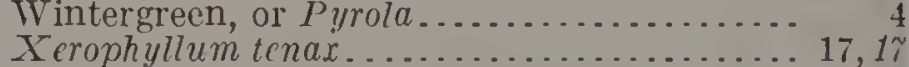

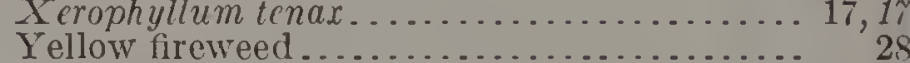

heather............................. 38,41

mustard ................................ 47 